THE CLOAK OF BEFORE, THE WRENCH / OF BEYOND: SPIRITUALITY, IDENTITY AND LANDSCAPE IN PAKEHA LITERARY

FICTION, 1975-2009

BY

\title{
LISA EYRE
}

A Thesis

Submitted to the Victoria University of Wellington in Fulfilment of the Requirements for the Degree of Master of Arts in Religious Studies

School of Art History, Classics and Religious Studies Victoria University of Wellington 



\section{CONTENTS}

ABSTRACT

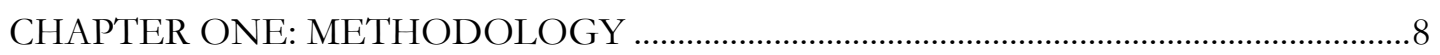

A Literary Methodology …....................................................................................

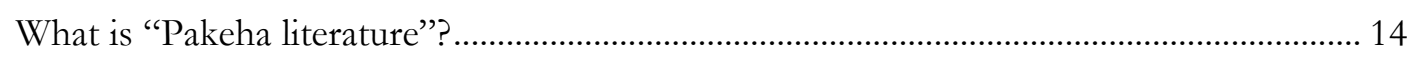

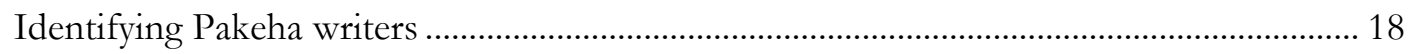

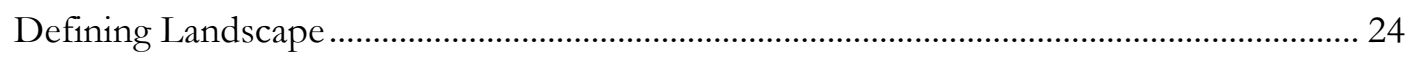

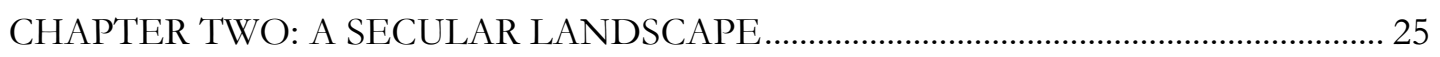

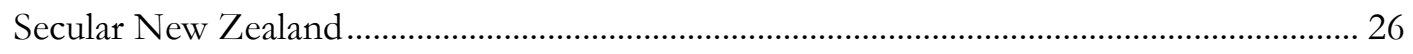

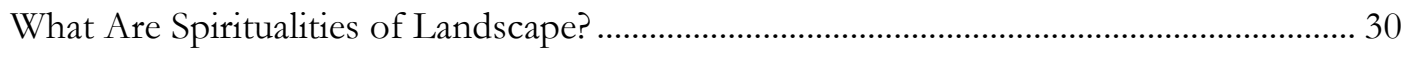

'there's evidently something / up there' ................................................................................... 35

CHAPTER THREE: BELONGING BY BEING AT HOME.............................................. 44

Part One: Spiritualities of Landscape in Pakeha Literary Fiction............................................ 44

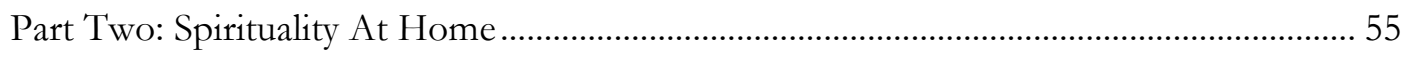

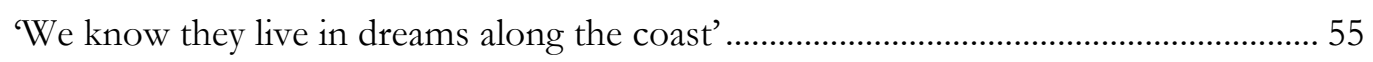

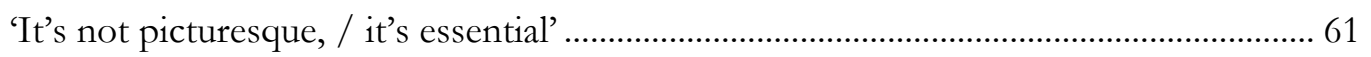

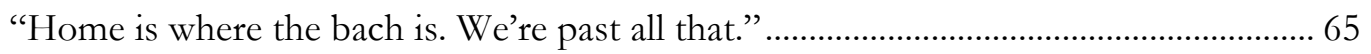

CHAPTER FOUR: THE PROBLEMS OF PAKEHA BELONGING …………………..... 71

Part One: Looking to the Landscape .................................................................................. 71

'Wherever I smell salt and feel sand blow against my skin, I have come home.'........... 72

Part Two: The Landscape Looks Back................................................................................. 81

'We're only now beginning to look closely at the place we're living in.'.......................... 81

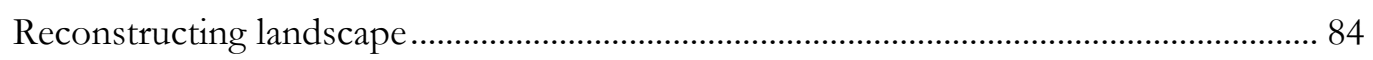

'What a change to take place within the next three-quarters of a century!'...................... 89

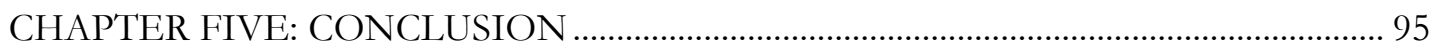

POSTSCRIPT: 'the cloak of before, the wrench / of beyond' ................................................ 107

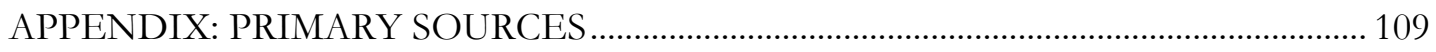

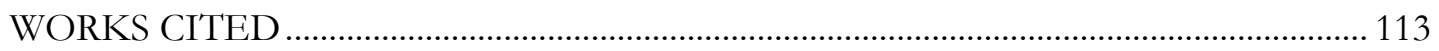




\section{ACKNOWLEDGEMENTS}

I thank Professor Paul Morris, Doctor Geoff Troughton, Aliki Kalliabetsos, Akvilina Cicenaite, Negar Partow, Timothy McVicar and William Hoverd from the Religious Studies Department for their advice, encouragement and good humour. I also thank Edric and Joy Eyre; Amber, Andrew, Finn and Ari Thomas; Cass Alexander, Katie Henry, Mike Lovelock and Nikki Baxter for their love and patience. I am indebted to Professor Paul Morris for his guidance, knowledge and continuing enthusiasm for this project. I am indebted to my parents and Amber Thomas for their considerable emotional and financial support. 


\begin{abstract}
This thesis takes a novel approach to Pakeha spiritual identities. Drawing on representations of landscape and spirituality in eighty-seven works of Pakeha literary fiction published between 1975 and 2009, it identifies complex and contested spiritualities of landscape as manifestations of the problems of Pakeha belonging. Key themes of belonging and desecration give voice to identity concerns that are submerged in popular avowals of a shared "love of the land". This thesis identifies Pakeha writers as an important voice for the articulation and construction of Pakeha spiritual identities. It illuminates the spiritual possibilities that are obscured by narrow conceptions of religion, spirituality and secularity, which allows a new exploration of the dynamic and developing nature of our landscapes, spiritualities and identities.
\end{abstract}

Key words: Spirituality, landscape, secularity, white settler cultures, Pakeha cultural identity, Pakeha literary fiction, Montana New Zealand Book Awards, New Zealand Post Book Awards. 


\section{INTRODUCTION}

New Zealand Listener reports that the defining feature of 'New Zealandness' is 'our relationship with the land', which is described as 'spiritual, even soulful'. ${ }^{1}$ The magazine cites recent research, which finds that 'New Zealanders' sense of selfdefinition is heavily bound up with love of the natural world'. ${ }^{2}$ These claims are not exceptional. North \& South includes 'a renewed sense of eco-spirituality, bound up with our unique Maori-Pakeha heritage and shared love of the land' as evidence of an enduring interest in religion and spirituality in New Zealand. ${ }^{3}$ These avowals resonate with the few articulations of "New Zealand spiritualities". Over a decade ago John Bluck included 'learn[ing] to listen to the silence of the bush' as 'a basic discipline of Kiwi spirituality'. ${ }^{4}$ More recently, Paul Morris locates land at the heart of New Zealand spiritualities in claiming, 'Aotearoa is the ground of our individual and collective life, it gives us our being and connects us to each other and our future. ${ }^{5}$

In this thesis I explore constructions of spirituality in landscape in eighty-seven works of Pakeha literary fiction published between 1975 and 2009. I articulate a theme of belonging that suggests many Pakeha explore and express their personal, collective, and spiritual identities in unfolding relationships with landscape. Yet, a theme of desecration indicates that the relationships between Pakeha, spirituality and landscape are more problematic than is suggested by a unifying "love of the land". Contextualising my findings in the crisis of Pakeha cultural identity of the 1980s and the identity

\footnotetext{
${ }^{1}$ Jane Clifton, “Choice, Bro," New Zealand Listener, July 3-9, 2010, 14, 16.

${ }^{2}$ Ibid., 14.

${ }^{3}$ Caroline Courtney, "Religion: Who Needs It?," North \& South, April 1, 2007, http://web.ebscohost.com/ 1998), 50 .

${ }^{4}$ John Bluck, Long, White and Cloudy: In Search of a Kiwi Spirituality (Christchurch: Hazard Press,

5 Paul Morris, "Who Are We? New Zealand Identity and Spirituality," in New Zealand Identities: Departures and Destinations, ed. James Liu, et al. (Wellington: Victoria University Press, 2005), 252; "Spirituality Abroad: Reflections on New Zealand Spirituality and Identity," in Spirit Abroad: A Second Selection of New Zealand Spiritual Verse, ed. Paul Morris, Harry Ricketts, and Mike Grimshaw (Auckland: Godwit, 2004), 227.
} 
concerns of white settler cultures, I identify complex and contested spiritualities of landscape as manifestations of the problems of Pakeha belonging. This thesis identifies Pakeha writers as an important vehicle for the articulation and construction of Pakeha spiritual identities. Unlike the received wisdom that claims New Zealand as secular, it illuminates spiritual possibilities that are obscured by narrow conceptions of religion, spirituality and secularity. This allows a novel interpretation of the dynamic and developing nature of our landscapes, spiritualities and identities.

This thesis has five chapters. In the first chapter I explain my choice of a literary methodology and outline the practical and theoretical issues that shaped my research. In Chapter Two I outline an understanding of spirituality that is informed by New Zealand's secularity and relatively recent shifts in secularisation theory. In Chapter Three I demonstrate common themes of belonging and home, which convey the importance of belonging to identity. Chapter Four is comprised of two parts. In the first part I discuss representations of landscape as a focus for shared experience and collective identities. I shift focus in the latter part to discuss a theme of desecration, as an illustrative example of the challenges to Pakeha belonging. In Chapter Five I draw the themes of belonging and desecration together to identify complex and contested spiritualities as manifestations of the problems of Pakeha belonging. 


\section{CHAPTER ONE}

\section{METHODOLOGY}

My primary sources are eighty-seven works of prose fiction and poetry written by fifty-four Pakeha writers and published between 1975 and 2009. The texts are drawn from winners of the fiction and poetry categories of the various forms of the Montana New Zealand Book Awards, and international literary prizes, between 1975 and 2010. ${ }^{1}$ In this section I explain my choice of a literary methodology and address some of the practical considerations that shaped my research. I then outline my definition and method of categorising Pakeha literature and writers before explaining my definition of "landscape".

\section{A Literary Methodology}

This thesis is shaped by New Zealand's secularity. As I discuss in Chapter Two, it informs my definition and approach to spirituality. And, as I discuss in this section, it drives my choice of a literary methodology.

As traditional forms of religion hold less resonance for an increasing number of New Zealanders, the country's religious institutions tell us less about collective concerns. ${ }^{2}$ The lack of authoritative religious or spiritual institutions in New Zealand contributes to muted public spiritual discourse, which creates challenges for researching spirituality. ${ }^{3}$ As Paul Morris, Harry Ricketts and Mike Grimshaw state, 'There is no easy

\footnotetext{
${ }^{1}$ Entrants in the various forms of the Montana New Zealand Book Awards must be published in the previous twelve months, thus the 2010 winners were published in 2009.

${ }^{2}$ For discussion on the decline of organised religion in New Zealand see pp. 26-27 below.

${ }^{3}$ Peter Matheson, "The Myth of a Secular New Zealand," Pacifica: Journal of the Melbourne College of Divinity 19, no. 2 (June 2006): 178; Lloyd Geering, 2100, A Faith Odyssey: The Changing Face of New Zealand Religion (Wellington: St Andrews Trust for the Study of Religion \& Society, 1995), 8-9; Rex Ahdar and John Stenhouse, introduction to God and Government: The New Zealand Experience, ed. Ahdar and Stenhouse (Dunedin: University of Otago Press, 2000), 9-11; Rex Ahdar, "Reflections on the Path of Religion-State Relations in New Zealand," Brigham Young University Law Review 2006, no. 3 (2006): 622-29. Ahdar and
} 
way to discover the rich tradition of our spirituality'. In their anthology, the first to collate New Zealand spiritual verse, they draw on mostly non-religious poetry rather than hymns or religious verse to articulate the richness and possibilities of New Zealand spiritual lives. $^{5}$

In this thesis I too draw on creative writers to provide a rich source of carefully considered representations that reflect, project and affect how people think and feel about themselves, their experiences and each other. ${ }^{6}$ As Paul Morris identifies, in a secular society such as New Zealand, creative writers are new kinds of theologians and priests who 'speak for us, of us and to us'. ${ }^{7}$ They put into words the fragmentary and elusive thoughts and feelings that make up and shape spiritual lives. They create a cultural discourse from which I can explore relationships between landscape, spirituality and Pakeha cultural identity.

This role for creative writers identifies literature as a dynamic cultural product that is in dialogue with other cultural products, institutions, and beings. It is supported by the view of people as cultural beings who, as Christina Stachurski describes, are 'moulded to a large extent by the worlds we live in and by words, images, sounds, texts . . , as well as by social and physical environments' ${ }^{8}$ This experience may be recognised at an individual level when a poem "speaks to us" by articulating our thoughts in a profound way or when the fictive worlds of novels provide windows into unfamiliar

Stenhouse demonstrate that public religious and spiritual discourse tends to focus on controversial events.

${ }^{4}$ Paul Morris, Harry Ricketts, and Mike Grimshaw, introduction to Spirit in a Strange Land: A Selection of New Zealand Spiritual Verse, ed. Morris, Ricketts, and Grimshaw (Auckland: Godwit, 2001), 14.

5 Ibid., 9.

${ }^{6}$ Lawrence Jones, "Versions of the Dream: Literature and the Search for Identity," in Culture and Identity in New Zealand, ed. David Novitz and Bill Willmott (Wellington: GP Books, 1989), 187; Jonathan Culler, Literary Theory: A Very Short Introduction, Very Short Introductions (Oxford: Oxford University Press, 1997), 82-83, 92, 110-13; Andrew Bennett and Nicholas Royle, An Introduction to Literature, Criticism and Theory (New York: Pearson Longman, 2004), 124.

7 Morris, "Who Are We?," 251; _—_ "Spirituality Abroad," 225; Paul Morris and Harry Ricketts, "Irreverent but Not Irreligious--Good Kiwi Joker Spirituality from Allen Curnow to Flight of the Conchords," Landfall 215 (2009): 95.

${ }^{8}$ Christina Stachurski, Reading Pakeha?: Fiction and Identity in Aotearoa New Zealand, Cross/Cultures 109 (Amsterdam: Rodopi, 2009), xxiii. Stachurski gives examples of texts as '(books, films, poems, songs, video clips, art works, magazines, advertisements, television, etc.)' 
lives, widening personal experience and challenging our understandings. ${ }^{9}$ At a group level, literary representations may reinforce, disrupt or illuminate aspects of collective and cultural identities, as they jostle or coalesce with readers' 'horizons of expectations' and dominant cultural constructions ${ }^{10}$ Keith Sinclair captures some of this experience when he states, 'Writers and scholars interpret our life; explore our identity. And their existence makes us feel different., ${ }^{11}$

Stuart Hall's discussion of the role of "Third Cinema" in the production of diaspora identities provides an instructive account of how creative representations can "make us feel different". Hall describes cultural identities as 'unstable points of identification or suture' that are made within and are subject to the discourses of history, language and culture. ${ }^{12}$ These points are fragmented and continually repositioned, as they are 'multiply constructed across different, often intersecting and antagonistic, discourses, practices and positions. ${ }^{, 13}$ Hall identifies cinema as one such discourse, describing it as a 'form of representation which is able to constitute us as new kinds of subjects, and thereby enable us to discover places from which to speak. ${ }^{, 14}$

This schema is in contrast with the idea of cultural identities as stable and essential, or the realisation of "who we really are" ${ }^{15}$ Thus, it dispels the view of creative representations as reflections of a pre-existing and underlying collective self. ${ }^{16}$ Rather, it identifies cinema and creative fiction - as another form of creative representation - as discourses through which people continually construct and reconstruct their ideas of

${ }^{9}$ Culler, Literary Theory, 59-60, 110-13; Morris, "Spirituality Abroad," 225.

${ }^{10}$ Jones, "Versions of the Dream," 187; Culler, Literary Theory, 40, 59-60, 63, 92, 110-16.

${ }^{11}$ Keith Sinclair, Towards 1990: Nation and Identity, Hocken Lecture 1988 (Dunedin: The Hocken Library, University of Otago, 1990), 14.

${ }^{12}$ Stuart Hall, "Cultural Identity and Diaspora," in Theorizing Diaspora: A Reader, ed. Jana Evans Braziel and Anita Mannur (Malden, MA: Blackwell, 2003), 237; —_, "Introduction: Who Needs 'Identity?,"' in Questions of Cultural Identity, ed. Stuart Hall and Paul du Gay (London: Sage, 1996), 4.

13 __ "Cultural Identity," 237-38; __ ,Who Needs 'Identity?,", 4.

14

15 Ibid., 236; — "Who Needs 'Identity”," 2-4.

16 _ , "Cultural Identity," 234, 236-7, 245; —_ "Who Needs 'Identity?,” 4. 
who they are and who they may become. ${ }^{17}$

Hall's identification of creative representations as a source and force in identity production supports my use of creative fiction as a source of information about Pakeha cultural identity. Yet, the processes he describes serve to remind me that creative fiction is an interdependent component within a larger narrative that is continually destabilised and rewritten. As the meaning and impact of creative fiction is subject to cultural, political and social forces, I am mindful that a literary study offers one viewpoint of a wider process. Thus, while I identify some commonalities, I do not suppose there is a unified or stable "Pakeha spiritual landscape discourse" within my selection of creative fiction that reflects the way Pakeha "really do" or ought to feel about landscape or spirituality. Rather, I identify creative representations that suggest possibilities for Pakeha constructions of landscape and spirituality. I explain some of the practical considerations that influenced my selection of primary sources, below.

Given Hall's schema, I focussed my selection of primary sources on texts that may have resonated with a Pakeha audience and contributed to cultural discourses. I surmised that literary fiction would likely attract a larger readership than specialist genres, such as environmental or landscape-focussed texts. I identified that studying a broad selection of literary fiction provided me with an opportunity to assess the currency of landscape and spiritual landscape themes within Pakeha literature. And, I concluded that a broad survey rather than close readings exposed me to a greater number of representations of landscape and spirituality.

New Zealand's literary scholars identify a range of fiction genres as sites for cultural discourse. For example, Terry Sturm identifies popular fiction as a window to the social issues and institutions that concern New Zealand's reading public. ${ }^{18}$ Lydia

17 _, "Cultural Identity," 245; __ ,Who Needs 'Identity'?," 4.

18 Terry Sturm, "Popular Fiction," in The Oxford History of New Zealand Literature in English, ed. Terry Sturm (1991; repr., Auckland: Oxford University Press, 1998), 579. 
Wevers claims that the short story is the genre of choice in New Zealand for exploring the complexities of postcolonial cultures and identities. ${ }^{19}$ More recently, Morris, Ricketts and Grimshaw contend that poetry has replaced the short story 'as the chosen vehicle for the expression of our identity and consciousness. ${ }^{, 20}$ My primary sources include texts from these genres.

I initially focussed on best-selling Pakeha literary fiction. I did not equate book sales with resonance but recognised that greater book sales increase the possibilities for resonance simply by reaching a larger audience. A "best sellers" selection was hindered, however, by a lack of historical book sales data. ${ }^{21}$ This sample also did not account for culturally significant works. I then focussed on "significant" Pakeha literary fiction, based on popular book reviews and literary criticism. This method was hindered, however, by a lack of book reviews in the 1970s and early 1980s. ${ }^{22}$ I abandoned this sample when I discovered that some of the texts receiving the greatest popular and academic attention had very small print runs, making them difficult to obtain, severely limiting their readership and, arguably, their contribution to cultural discourses. My reading of these texts serves to assure me, however, that the content of my eventual selection is comparable to other works of Pakeha literary fiction.

My eventual selection of primary sources is drawn from the winners of the various forms of the Montana New Zealand Book Awards, the Commonwealth Poetry Prize, and the Commonwealth Writers Prize. As I discuss shortly, I limited my selection to titles that were published between 1975 and 2010. This selection includes winners of the James Wattie New Zealand Book of the Year / Goodman Fielder Wattie Book

46.

${ }^{19}$ Lydia Wevers, "The Short Story," in The Oxford History of New Zealand Literature in English, 245-

${ }^{20}$ Morris, Ricketts, and Grimshaw, introduction, 11.

21 Anna Hutchinson, New Zealand Booksellers, telephone conversation with author, November 4, 2009. Hutchinson advised that reliable sales data is only available from 2003 when Nielson Data entered the New Zealand market. Prior to 2003 Booksellers New Zealand reported informal lists gathered from a few retailers in their newsletter, "Booksellers News".

22 The weekly "Book Marks" column in New Zealand Listener was the only regular source of popular book reviews. Landfall and lslands provided irregular scholarly reviews to a limited readership. 
Award (1968-1993), which became the Montana Book Awards in 1994, and the New Zealand Book Awards (1976-1995). The two awards merged to create the Montana New Zealand Book Awards in 1996. ${ }^{23}$ They were renamed the New Zealand Post Book Awards in $2010 .^{24}$

My selection includes winners of the first, second and third placing in the Goodman Fielder Wattie Book Awards, as the first placing was dominated by nonfiction titles. The names and categories of the various forms of the Montana New Zealand Book Awards have changed over the years but I included winners of the Deutz Medal for Fiction, the fiction and poetry categories, and any fiction or poetry winners of the reader's choice prizes. I included winners of international literary prizes to capture other significant works, which added winners of the Commonwealth Poetry Prize and the Commonwealth Writers Prize to my selection. As some publications won multiple awards, this source yielded eighty-seven books by fifty-four Pakeha writers, comprised of forty novels, six books of short stories and forty-one books of poetry.

The Montana New Zealand Book Awards are New Zealand's major book prizes and, while they do not guarantee readership or resonance, winning one of the awards usually increases domestic sales. ${ }^{25}$ The aims of the various awards have evolved over the past thirty-five years but have focussed on recognising excellence in, and encouraging readership of, quality New Zealand literature. ${ }^{26}$ The awards have been criticised for their literary leanings but I contend that New Zealand's literary scene remains at a level where

${ }^{23}$ The history of the awards may be tracked in the annual editions of the New Zealand Books in Print from 1976 to present. For an example see Lis Whyte, ed., New Zealand Books in Print (Wellington: DW Thorpe, 1995).

${ }^{24}$ Booksellers New Zealand, "About the NZ Post Book Awards," http:/ /www.booksellers.co.nz/awards/new-zealand-post-book-awards/about-nz-post-book-awards.

${ }^{25}$ Margie Thomson, "Judgment Day for the Montana Book Awards," New Zealand Herald, July 20, 2002, http://www.nzherald.co.nz/margie-thomson/news/article.cfm?a_id=108\&objectid=2098172

${ }^{26}$ The aims of the variously titled Goodman Fielder Wattie Book Awards, New Zealand Book Awards, and Montana New Zealand Book Awards are printed in the annual editions of New Zealand Books in Print. For an example see Whyte, ed., New Zealand Books in Print, xxvii. 
award winners are unlikely to be significantly distinct from other literary output. ${ }^{27}$ The popular fiction leanings of recent winners, such as Craig Marriner's Stonedogs and Charlotte Grimshaw's Opportunity, supports this point. This selection of literary fiction allows me to focus on quality literature that may have contributed to cultural discourses and resonated with a Pakeha audience. I explain how I defined and categorised Pakeha literature and writers, below.

\section{What is "Pakeha literature"?}

One of the first questions I considered in selecting my primary sources was: what is "Pakeha literature"? The contestations that surround Pakeha cultural identity complicate any answers. Discussions of a "New Zealand literature" usually begin with the cultural nationalist constructions associated with Provincial period writers, who undertook an influential phase of self-exploration and cultural questioning from the 1930s to $1950 \mathrm{~s}^{28}$ This movement of writers is typified by its concern with establishing a cultural literature to articulate and signal the achievement of a distinct national identity. ${ }^{29}$ Their efforts are exemplified by Charles Brasch's literary quarterly, Landfall; Monte Holcroft's essays and Allen Curnow's influential poetry anthologies. ${ }^{30}$

In 1945 Allen Curnow articulated his view of the relationship between creative

\footnotetext{
${ }^{27}$ New Zealand Listener, “The Good Books,” June 13-19, 2009, http:/ /www.listener.co.nz/issue/ 3605/columnists/13441/the_good_books.html.

${ }^{28}$ Alex Calder, "Unsettling Settlement: Poetry and Nationalism in Aotearoa / New Zealand," in Real: Yearbook of Research in English and American Literature 14, Literature and the Nation, ed. Thomas Brook (Tübingen: Gunter Narr Verlag, 1998), 165-66.

${ }^{29}$ Ibid; Lawrence Jones, Picking up the Traces: The Making of a New Zealand Literary Culture, 19321945 (Wellington: Victoria University Press, 2004), 14; Hugh Roberts, "Can Identity Be Helped? 'Landfall', Chaos, and the Creation of a New Zealand National Literature," Journal of New Zealand Literature 14 (1996): 24; ___ "The Same People Living in Different Places: Allen Curnow's Anthology and New Zealand Literary History," Modern Language Quarterly 64, no. 2 (June 2003): 221-22.

${ }^{30}$ Calder, "Unsettling Settlement," 165-66; Jones, Picking up the Traces, 14, 18; Roberts, "Can Identity Be Helped?,” 24, 26-27; —_ " "The Same People,” 219, 220, 222; Patrick Evans, "On Originality: No Earth Tones," in Writing at the Edge of the Universe: Essays from the "Creative Writing in New Zealand' Conference, University of Canterbury, August 2003, ed. Mark Williams (Christchurch: Canterbury University Press, 2004), 75; Allen Curnow, ed., A Book of New Zealand Verse, 1923-45 (Christchurch: The Caxton Press, 1945); — ed. The Penguin Book of New Zealand Verse (Harmondsworth: Penguin Books, 1960); MH Holcroft, Discovered Isles: A Trilogy (Christchurch: The Caxton Press, 1950).
} 
artists and New Zealand national identity, stating:

Strictly speaking, New Zealand doesn't exist yet, though some possible New Zealands glimmer in some poems and on some canvasses. It remains to be created-should I say invented-by writers, musicians, artists, architects, publishers; even a politician might help—and how many generations does that take?31

Although his aims and accomplishments were nationalist in focus, Curnow's concern for the development of a "national" character was largely a concern for the Pakeha character. ${ }^{32}$ Indeed, the introduction to his 1960 poetry anthology, A Book of New Zealand Verse, has been described as a 'manifesto of Pakeha identity. ${ }^{33}$ In this and his 1945 anthology, Curnow presented his selection of 'more hopeful verse', which included works that challenged prevailing nationalist constructions. ${ }^{34}$ This verse, united by a 'theme of land and people', and later described as an 'anti-myth', re-imagined a national consciousness troubled by a disjunction between body and spirit. ${ }^{35}$ The antimyth had a profound effect on New Zealand's literary scene and constructions of Pakeha cultural identity. ${ }^{36}$ Contemporary discussions of Pakeha identity often draw upon cultural nationalist poetry as a touchstone, marking how little or far Pakeha have come in feeling like 'interlopers on an indifferent or hostile scene'. ${ }^{37}$

Curnow's view of a national literature was grounded in a particular role for New

\footnotetext{
31 Allen Curnow, “A Dialogue by Way of Introduction, with Ngaio Marsh,” Yearbook of the Arts 1 (Wellington: Harry H Tombs, 1945) quoted in Calder, "Unsettling Settlement," 165.

${ }^{32}$ Jones, Picking up the Traces, 15, 17; Roberts, "The Same People," 220.

33 Mike Grimshaw, "'I to the Hills Will Lift Mine Eyes, from Whence Will Come My Aid!' or, Pakeha and the Condition of Modernity" (paper presented at the Transformations '07: Composing the Nation: Ideas, Peoples, Histories, Languages, Cultures, Economies. The Congress of Te Whainga Aronui, The Council for the Humanities, Victoria University of Wellington, August 27-28, 2007), http://www.humanitiesresearch.net/news/i_to_the_hills_will_lift_mine_eyes_from_whence_will_come_ my_aid_or_pakeha_and_the_condition_of_modernity

${ }^{34}$ Curnow, ed. Book of New Zealand Verse, 14-15, 21; _ _ ed. Penguin Book of New Zealand Verse 18-20, 37; Jones, Picking up the Traces, 173-75; Roberts, "The Same People," 227.

${ }^{35}$ Curnow, ed. Book of New Zealand Verse, 18, 20-24, 28, 43, 52; —_, ed. Penguin Book of New Zealand Verse 17, 20-21, 45, 51, 55; Jones, Picking up the Traces, 173-74, 185; Roberts, "The Same People," 228-29; Grimshaw, "I to the Hills".

${ }^{36}$ Roberts, "The Same People," 222; Peter Gibbons, “The Far Side of the Search for Identity: Reconsidering New Zealand History,” New Zealand Journal of History 37, no. 1 (2003): 1; Trudie McNaughton, ed., Countless Signs: The New Zealand Landscape in Literature (Auckland: Reed Methuen Publishers Ltd, 1986), 8.

${ }^{37}$ Curnow, ed. Book of New Zealand Verse, 52.
} 
Zealand's creative artists. During the Provincial period, Curnow and James K. Baxter separately and seminally cast the creative writer as an outsider, tasked with critiquing society's dominant cultural constructions. ${ }^{38}$ In 1945 Curnow described the role of the poet, as 'the nerve to the body of his race, feeling and declaring the need or sickness which all suffer. ${ }^{39}$ In 1951 Baxter espoused a similar view, if not assessment, of the poet's social role, declaring, "We have a greater need of prophets than we have of mechanics." 40 The Provincial writers remain influential but the role and aims of Postprovincial writers have changed, alongside new opinions on what constitutes a cultural literature. ${ }^{41}$

This change in position has been accompanied by critiques and revisions of Provincial period constructions. Curnow's literary landscape has been criticised as 'too male, too Pakeha, too Anglophile'.42 The 'moments of rebellion' expressed by his generation have become part of the literary establishment subsequent writers have sought to challenge. ${ }^{43}$ Within my selection of Pakeha literary fiction, Beryl Fletcher articulates one such challenge when she writes, 'It's a Pakeha disease, this need for security, the alienation of the colonial identity and all that shit. The boring obsession of male writers in my country, forever wanting to know who we are, the "we" referring to Pakeha males. ${ }^{, 44}$

There is little accord on how to redefine New Zealand or Pakeha literature. Miles Fairburn traces key literary themes to global antecedents in claiming there is

\footnotetext{
38 Jones, "The Novel," in The Oxford History of New Zealand Literature in English 152; _- , "Versions of the Dream," 201.

${ }^{39}$ Curnow, ed. Book of New Zealand Verse, 46. Curnow reaffirmed this view in Penguin Book of New Zealand Verse, 17-18.

${ }^{40}$ James K. Baxter quoted in Peter Simpson, “A Country in Search of Itself," in Writing at the Edge of the Universe, 134.

${ }^{41}$ Elizabeth Caffin, "Poetry, Part Two: 1945-1990s," in The Oxford History of New Zealand

Literature in English, 498; Jones, “The Novel," 178; Roberts, "Can Identity Be Helped?," 25.

${ }^{42}$ Roberts, “The Same People," 220.

${ }^{43}$ Evans, "On Originality," 75.

${ }^{44}$ Beryl Fletcher, The Word Burners (Wellington: Daphne Brasell Associates, 1991), 114.
} 
nothing exceptional about Pakeha culture. ${ }^{45}$ Conversely, Lawrence Jones claims Postprovincial writers critique society, as citizens rather than outsiders, with certainty of their cultural identities. ${ }^{46}$ Recently, Patrick Evans reignited debate over the role of New Zealand's writers by criticising Bill Manhire's tertiary creative writing course for creating globalised 'literary products'. ${ }^{47}$ Evans identifies a shift away from a local focus in relatively recent successful publications, such as Elizabeth Knox's The Vintner's Luck, and asks, 'Are these still New Zealand novels?"48 Mark Williams responds in the affirmative, but acknowledges that the role of the writer as,

prophet, outcast, lover or larrikin producing work out of torment and inspiration has given way to the writer amongst us, an unspectacular but productive inhabitant of the common world, noticing what we take for granted and making it strange. ${ }^{49}$

Recent assessments and literary anthologies stress the plurality and difference in New Zealand's literary output rather than prescribe what New Zealand or Pakeha literature ought to be ${ }^{50}$ I too acknowledge the diversity, possibilities and contestability of New Zealand literature by defining Pakeha literature broadly, as 'literary works by Pakeha writers'.

To make use of this definition I must ask, 'who is a Pakeha writer?', which leads me to question, 'what is "Pakeha"?' With these questions I am immediately confronted with the uncertainty and contention that surrounds most aspects of Pakeha cultural identity. Even a brief survey of local identity discourse suggests constructions of Pakeha cultural identity lie in contested ground. A more sustained inquiry reveals that ideas

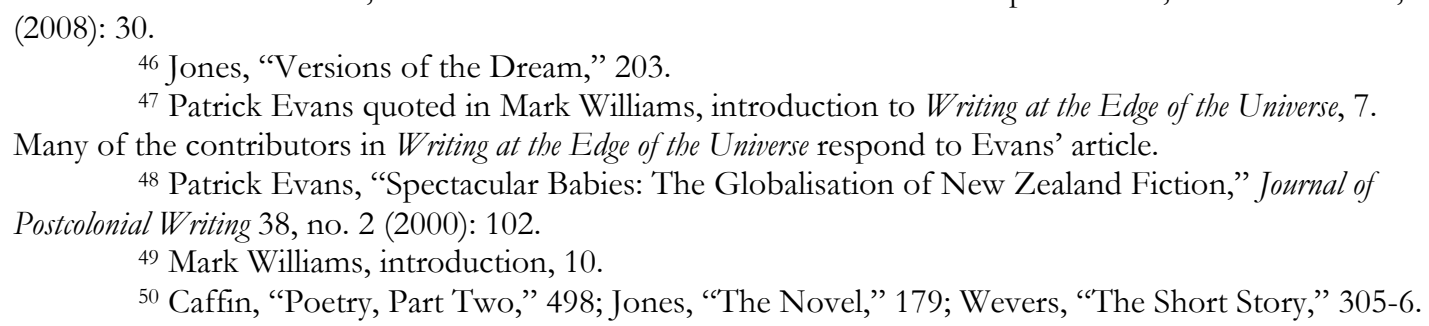

46 Jones, "Versions of the Dream," 203.

${ }^{47}$ Patrick Evans quoted in Mark Williams, introduction to Writing at the Edge of the Universe, 7. Many of the contributors in Writing at the Edge of the Universe respond to Evans' article.

${ }^{48}$ Patrick Evans, "Spectacular Babies: The Globalisation of New Zealand Fiction," Journal of Postcolonial Writing 38, no. 2 (2000): 102.

${ }^{49}$ Mark Williams, introduction, 10.

${ }^{50}$ Caffin, "Poetry, Part Two," 498; Jones, “The Novel,” 179; Wevers, “The Short Story," 305-6.

${ }^{45}$ Miles Fairburn, "Is There a Good Case for New Zealand Exceptionalism?," Thesis Eleven 92, 
about the legitimacy, contours and very existence of Pakeha cultural identity are subject to voracious popular and academic debate. In the following section I discuss some of the prominent conceptions and definitions of Pakeha cultural and ethnic identities that I considered in collating my selection of Pakeha literary fiction. The purpose of this section is to explain why I broadly categorise Pakeha writers and literature. I do not attempt to define Pakeha as an ethnic or cultural group.

\section{Identifying Pakeha writers}

The scope of this thesis is 1975 to 2009. This thirty-four year time frame covers a period of significant cultural, social and political upheaval in New Zealand. In the mid-1970s and 1980s Pakeha were faced with a deepening crisis of identity as key events, such as the Maori Renaissance and loosening economic and cultural ties with Britain, forced many Pakeha to question their cultural legitimacy, their coupling of land and identity, and their comfort in looking so close for Home. ${ }^{51}$ Watershed events, such as 1975 Maori Land March, the occupation of Bastion Point, and the response to the 1981 anti-Springbok tour protests brought Maori land rights and Treaty of Waitangi grievances to the fore of New Zealand's public life. ${ }^{52}$ Just two years earlier Britain had entered the European Economic Community, rupturing the bond between New Zealand and its "mother country" ${ }^{33}$ Around the same time, a growing environmental movement thrust the protection and desecration of New Zealand's landscape onto a national stage. The 'Save Manapouri' campaign, which reached its height in the early

51 James Belich, Paradise Reforged: A History of the New Zealanders from the 1880s to the Year 2000 (Auckland: Allan Lane / Penguin, 2001), 425, 465, 487, 515; David Pearson, "Pakeha Ethnicity: Concept or Conundrum," Sites: A Journal for Radical Perspectives on Culture 18 (Winter 1989): 68-69.

52 Belich, Paradise Reforged, 477-78; Claudia Bell, Inventing New Zealand: Everyday Myths of Pakeha Identity (Auckland: Penguin, 1996), 26-27; Evan Te Ahu Poata-Smith, "He Pokeke Uenuku I Tu Ai: The Evolution of Contemporary Maori Protest," in NgäPatai: Racism and Ethnic Relations in Aotearoa/New Zealand, ed. Paul Spoonley, David Pearson, and Cluny Macpherson (Palmerston North: Dunmore Press, 1996), 97, 105; Paul Spoonley et al., introduction to Nga Tauiwi: Racism and Ethnicity in New Zealand (Palmerston North: Dunmore Press, 1984), 9, 12.

${ }^{53}$ Belich, Paradise Reforged, 425, 431-35; Philip Steer, "History (Never) Repeats: Pakeha Identity, Novels and the New Zealand Wars," Journal of New Zealand Literature 25 (2007): 120. 
1970s, helped to propel environmentalism from a special interest to a popular and national concern. ${ }^{54}$ Thus, at the time many Pakeha were seeking to redefine their identities with their eyes trained closer to home, landscape posed troubling questions over cultural legitimacy, belonging and culpability for an ongoing process of rapid ecological change. This crisis of identity provides the context for subsequent reconstructions of Pakeha cultural identity, which I discuss below.

In 1989 David Pearson identified Pakeha ethnicity as a relatively new and 'troublesome' concept. ${ }^{55}$ Working with Anthony Smith's influential conceptualisation of ethnicity, Pearson argues that Pakeha are not an ethnic community as they lack a distinct shared culture and sense of solidarity. ${ }^{56} \mathrm{He}$ describes the identification of something distinctive or unique about Pakeha culture as elusive and even unattainable. ${ }^{57}$ He also considers different definitions of "Pakeha" and finds them either imprecise or externally imposed. ${ }^{58}$ Pearson's assessment of Pakeha ethnicity as problematic and uncertain is corroborated by James Liu's research on Pakeha perceptions of social identity and history. Liu reports that only 35 percent of Pakeha respondents agree that a 'Pakeha identity' exists and many have difficulty identifying its traits. ${ }^{59}$ Avril Bell reports similar findings. Her interviews with Pakeha born in the late 1970s and early 1980s suggest Pakeha self-affiliation is troubled by uncertainty on how to define Pakeha cultural identity. ${ }^{60}$ In the following section I discuss two influential conceptions of Pakeha cultural identity and my reasons for adopting a broad definition for the purpose of identifying Pakeha writers.

\footnotetext{
${ }^{54}$ Belich, Paradise Reforged, 519, 530-31. Belich notes that the protests peaked in 1971.

${ }^{55}$ Pearson, "Concept or Conundrum," 61.

56 Ibid.: 61, 66, 70 .

${ }^{57}$ Ibid.: 66.

58 Ibid.: 62-65.

${ }^{59}$ James H. Liu, "History and Identity: A System of Checks and Balances for Aotearoa/New Zealand," in New Zealand Identities: Departures and Destinations, ed. James Liu, et al. (Wellington: Victoria

60 Avril Bell, "Dilemmas of Settler Belonging: Roots, Routes and Redemption in New Zealand National Identity Claims," The Sociological Review 57, no. 1 (2009): 148, 152.
} University Press, 2005), 78. 
In the mid-1980s and late 1990s Michael King catalysed a round of identity debate with his influential portrayal of a distinct Pakeha culture founded in a transformative and indigenising relationship with New Zealand's landscapes and peoples. ${ }^{61}$ In Being Pakeha Now: Reflections and Recollections of a White Native King describes Pakeha as 'people and influences that derive originally from Europe but which are no longer "European". ${ }^{62}$ He describes his own sense of his Pakeha identity as 'a non-Maori New Zealander who is aware of and proud of my antecedents, but who identifies as intimately with this land, as intensively and as strongly, as anybody Maori. ${ }^{63}$

King argues that a distinct Pakeha culture emerged from this identification and commitment to New Zealand, the land and its peoples. ${ }^{64}$ His argument notably places a relationship with Maori at the core of Pakeha cultural identity. ${ }^{65}$ Yet, King's portrayal of this relationship and its wider implications for Pakeha and Maori are far from accepted. His conflation of cultural distinction with claims to indigeneity has attracted criticism for re-historicising Pakeha interactions with Maori and landscape, and undermining the status of Maori as tangata whenua ("the people of the land"), amongst other critiques. ${ }^{66}$ Although popular and influential, King's conception of Pakeha cultural identity is unsuitable as a basis for categorising Pakeha writers. Beyond its contestability, it requires an impracticable external assessment using subjective and imprecise criteria.

Paul Spoonley's claim that the experience of social and cultural dominance has

\footnotetext{
61 _- "We're Just New Zealanders': Pakeha Identity Politics," in Nga Patai: Racism and Ethnic Relations in Aotearoa/New Zealand, 146; Lydia Wevers, "Being Pakeha: The Politics of Location," Journal of New Zealand Studies, no. 4-5 (2005-2006): 2; Bell, Inventing New Zealand, 26; Lynda Dyson, "The Construction and Reconstruction of 'Whiteness' in New Zealand," British Review of New Zealand Studies 9 (December 1996): 63; Michael King, Being Pakeha Now: Reflections and Recollections of a White Native (Auckland: Penguin, 1999), 11, 235.

62 King, Being Pakeha Now, 10.

${ }^{63}$ Ibid., 239.

${ }^{64}$ Ibid., 235, 11.

${ }^{65}$ Bell, "We're Just New Zealanders," 147; Bell, Inventing New Zealand, 26.

${ }^{66}$ King, Being Pakeha Now, 235-39; Michael King, Pakeha: The Quest for Identity in New Zealand (Auckland: Penguin, 1991), 12; Liu, "History and Identity," 79; Dyson, "Construction and Reconstruction," 63-67; Wevers, "Being Pakeha," 2; Stephen Turner, "Being Colonial/Colonial Being," Journal of New Zealand Literature 20 (2002): 50-52.
} 
shaped Pakeha cultural values also locates a relationship with Maori at the core of Pakeha cultural identity. ${ }^{67}$ His definition of Pakeha as 'New Zealanders of a European background, whose cultural values and behaviour have been primarily formed from the experience of being a member of the dominant group of New Zealand' has gained greater acceptance in New Zealand's social sciences academy and Avril Bell claims it has gained widespread acceptance by Pakeha. ${ }^{68}$ Yet, Liu's research reports that many Pakeha survey respondents reject any ethnic affiliation let alone one defined by the experience of social and cultural dominance. ${ }^{69}$ Indeed, Liu links the rejection by Pakeha of "Pakeha" as an ethnic label to its association with Maori grievances. ${ }^{70}$

Spoonley's grouping of Pakeha by cultural values and behaviour is more readily measurable than King's categorisation by a commitment or an intimacy with the land. Yet, the need to determine appropriate indicators for Pakeha values and behaviour makes Spoonley's definition a complex and imprecise basis from which to categorise Pakeha writers. If I used some combination of weighted factors, such as being New Zealand born or receiving a New Zealand-based education, as a proxy for an exposure to and absorption of Pakeha values and behavior, I would have to question whether prominent writers such as M.K. Joseph, Peter Hooper and Ian Wedde were "Pakeha enough" to meet Spoonley's definition. ${ }^{71}$ It would be impractical and difficult to collate a meaningful sample of Pakeha literature using such a process.

\footnotetext{
${ }^{67}$ Bell, "We're Just New Zealanders," 147.

${ }^{68}$ Paul Spoonley, Racism and Ethnicity, Critical Issues in New Zealand Society (Auckland: Oxford University Press, 1988), 63-64; Augie Fleras and Paul Spoonley, Recalling Aotearoa: Indigenous Politics and Ethnic Relations in New Zealand (Auckland: Oxford University Press, 1999), 83; Bell, "We're Just New Zealanders," 147.

${ }^{69}$ Liu, "History and Identity," 78. Avril Bell discusses similar findings from 1993 in Bell, "We're Just New Zealanders," 144-45, and from 1997 in Bell, "Bifurcation or Entanglement? Settler Identity and Biculturalism in Aotearoa New Zealand," Continuum 20, no. 2 (2006): 264. Zealanders," 145.

${ }^{70}$ Liu, "History and Identity," 78. Avril Bell draws a similar conclusion in Bell, "We're Just New

${ }^{71}$ M.K. Joseph was born in England and emigrated to New Zealand at ten years old. Peter Hooper was born in England and emigrated to New Zealand at four years old. Ian Wedde lived outside of New Zealand from seven to fifteen. See further biographical information under the authors' entries at New Zealand Book Council, “The Writers Files,” http://www.bookcouncil.org.nz/Writers/ Information/Introduction.htm
} 
The unsuitability and contestability of these two influential definitions indicates that I require a broader method of identification. Thus, for the purpose of categorising Pakeha writers, I broadly define Pakeha as 'New Zealanders of European ancestry'. This definition references a shared ancestry, nationality and citizenship but is silent on the "fuzzy" attributes of cultural identities. It includes New Zealanders of European ancestries who prefer to identify as "New Zealand European", "New Zealanders" or even "Kiwi". It excludes New Zealanders of European ancestry who primarily selfaffiliate with a different ethnic group.

To identify Pakeha writers I reviewed biographical information and categorised all writers who seemed to be New Zealanders of European ancestry as Pakeha, unless I found evidence that they primarily self-identified with another cultural identity or ethnic group. The entry criteria of the various forms of the Montana New Zealand Book Awards made this process easier, as most variations of the awards specify that entrants must be New Zealand citizens or residents. ${ }^{72}$ I was then fortunate to discover that New Zealand writers' ancestries and any interesting aspects of cultural identity are usually noted on book jackets, publicity materials and publishers' websites or in The Oxford Companion to New Zealand Literature (including the New Zealand Book Council's updated online version, “The Writers Files”). ${ }^{73}$ Once I had collated a list of seemingly Pakeha writers, I attempted to mitigate the fallibility of externally categorising cultural identity by researching and accepting any divergent identity claims.

Keri Hulme's identification as a Maori writer provides one example of a writer's identity claims modifying my initial categorisation. The controversy surrounding Hulme's identity claims also demonstrates the contested space identity, and particularly

\footnotetext{
72 The entry criteria of the various Goodman Fielder Wattie Book Award, New Zealand Book Awards, and Montana Book New Zealand Book Awards are printed in the annual edition of New Zealand Books in Print from 1976 to present. For an example see Whyte, ed., New Zealand Books in Print, xxvii.

${ }^{73}$ Roger Robinson and Nelson Wattie, eds., The Oxford Companion to New Zealand Literature (Melbourne: Oxford University Press, 1998); New Zealand Book Council, “The Writers Files.”
} 
Pakeha cultural identity, resides in. Hulme's Booker Prize-winning novel, the bone people, was included in my initial sample of Pakeha literary fiction as it won the New Zealand Book Award for Fiction in 1984 and Hulme recognises English, Scottish and Maori ancestry. ${ }^{74}$ Yet, Hulme self-identifies as a Maori writer, stating:

I think of myself as a Maori writer rather than Pakeha that's the strong and the vivid and the embracing, the good side of things. [sic] That's where I draw my strength from. ${ }^{75}$

In 1984 Hulme's contribution to Maori literature was recognised when she received the Pegasus Prize for Maori Literature for the bone people. ${ }^{76}$ Local literary figure, C.K. Stead, challenged Hulme's receipt of the prize in stating, 'The Bone People, I would be inclined to argue, is a novel by a Pakeha which has won an award intended for a Maori. ${ }^{, 77}$ To support his view, Stead dismisses Hulme's identification as Maori to place greater weight on her mostly European ancestry and upbringing, offers his assessment that her use of Maori mythology and language is 'not entirely authentic', and notes the supposed social advantages of identifying as Maori. ${ }^{78}$ Unlike Stead, I accept Hulme’s self-identification and excluded the novel from my primary sources. This example serves to demonstrate the complexities and contention surrounding ethnicity, culture and identity in New Zealand. Although I have endeavoured to collate a meaningful selection of Pakeha literary fiction, the uncertainty surrounding Pakeha cultural identity lends fallibility to any method of identification.

I must acknowledge that my findings are likely to be influenced by my Pakeha cultural heritage and experiences of living in New Zealand. My findings are no doubt

\footnotetext{
${ }^{74}$ C.K. Stead, "Keri Hulme's 'the Bone People' and the Pegasus Award for Maori Literature," Ariel: A Review of International English Literature 16, no. 4 (1985): 101; New Zealand Book Council, "Hulme, Keri," http://www.bookcouncil.org.nz/Writers/Profiles/Hulme, Keri

${ }^{75}$ New Zealand Book Council, "Hulme, Keri."

${ }^{76}$ Stead, "Keri Hulme," 101; New Zealand Book Council, "Hulme, Keri."

77 Stead, "Keri Hulme," 101-08.

78 Ibid.: 103-04.
} 
influenced by my position as a Pakeha woman born in the lower North Island five years after the beginning of my timeframe. I have absorbed, experienced and recalled many of the landscapes of cultural significance to Pakeha from near and afar. I can trace my roots in this country to 1848 but locate my sense of cultural identity somewhere in the social and cultural upheaval that culminated in the years following my birth. These facts and feelings colour my perspective and findings. Yet, I believe that others undertaking a similar study could identify similar themes and draw comparable conclusions.

\section{Defining Landscape}

Finally, I use the term "landscape" over "land" or "nature" to acknowledge that the concept of landscape is an ongoing cultural construction or 'a culture's picture of the land'. ${ }^{79}$ As Simon Schama claims, 'Landscapes are culture before they are nature; constructs of the imagination projected onto wood and water and rock. ${ }^{80}$ Thus, while any environment can be landscape, my focus is on New Zealand's natural environment and ways of living in and identifying with it. As stated, I have firsthand knowledge of culturally significant landscapes, such the bush and beach, but I do not limit my focus to these locations or any other strict definition. In the next chapter I discuss New Zealand's secularity to contextualise my definition and approach to spirituality.

${ }^{79}$ Thomas R. Dunlap, Nature and the English Diaspora: Environment and History in the United States, Canada, Australia, and New Zealand, Studies in Environment and History (Cambridge: Cambridge University Press, 1999), 5, 12; Terry Goldie, Fear and Temptation: The Image of the Indigene in Canadian, Australian and New Zealand Literatures (Kingston, Ontario: McGill-Queen's University Press, 1989), 20. ${ }^{80}$ Simon Schama, Landscape and Memory (London: Fontana Press, 1996), 61. 


\section{CHAPTER TWO}

\section{A SECULAR LANDSCAPE}

In the early 1980s Lloyd Geering attributed New Zealand's secularity and tempered 'religious character' to the coterminous timing of the nation's 'birth' and the emergence of the 'Secular Age'. 'Since Geering made this statement, New Zealand's position as a particularly secular society has been reinforced, as census results have prompted diagnoses of 'general religious apathy' while social and legal changes have further eroded the country's de facto Christian establishment. ${ }^{2}$ In the same period, calls for the abandonment of universal secularisation theories gained greater strength. ${ }^{3}$ New understandings of religion and secularity are central to those calls. ${ }^{4}$

In the first section of this chapter I discuss New Zealand's secularity to contextualise my understanding of spirituality. Drawing upon relatively recent shifts in secularisation theory, I then outline an understanding of spirituality focussed on landscape and shaped by New Zealand's “conditions of belief”, Charles Taylor's idea of "fullness", Thomas Luckmann's levels of transcendence and awareness that a spiritual reading of secular texts is an act of construction. This understanding guides my exploration of representations of spirituality and landscape in Pakeha literary fiction. In the last section of this chapter I demonstrate how New Zealand's secularity is reflected within my primary sources. The examples I give illuminate the spiritual possibilities existent within secularity and the influence New Zealand's conditions of belief have on

${ }^{1}$ Lloyd Geering, "New Zealand Enters the Secular Age," in Religion in New Zealand, ed. Christopher Nichol and James Veitch, 2nd ed. (Wellington: Christopher Nichol / Victoria University of Wellington, 1983), 184-85. Rex Ahdar makes the same point in Ahdar, "Reflections," 623.

2 Paul Morris, "Fragments of Faith: Religion in Contemporary New Zealand," New Zealand Studies 9, no. 1 (March 1999): 18; Peter Donovan, "Zeal and Apathy: The Future," in Religions of New Zealanders, ed. Peter Donovan (Palmerston North: Dunmore Press, 1996), 268; Ahdar, "Reflections," 619, 629-32; Ahdar and Stenhouse, introduction, 15.

${ }^{3}$ Kevin M. Schultz, "Secularization: A Bibliographic Essay," The Hedgehog Review 8, no. 1-2 (Spring \& Summer 2006): 170, 174-75; THR, “After Secularization,” The Hedgehog Review 8, no. 1-2 (Spring \& Summer 2006): 5 .

${ }^{4}$ Schultz, "Secularization," 171; THR, "After Secularization," 6. 
spiritual themes. ${ }^{5}$

\section{Secular New Zealand}

While New Zealand has never had an established church, Christianity is a significant, if sometimes overlooked, social, political and cultural influence, providing the basis for a 'generic' de facto Christian establishment. ${ }^{6}$ Some historians claim New Zealand has never been particularly religious and question the relevance of historic census figures to "active" belief. ${ }^{7}$ But others accord Christianity an extensive role in the lives of New Zealanders until the 1960s, as Christian holidays and church activities structured social lives while Christian values shaped laws and social mores. ${ }^{8}$ They identify social changes in the 1960s, however, that saw church membership decline and Christianity's 'public face' fade. 'By 1976, analysis accompanying the national census observed that New Zealand's historically dominant, or traditional, Christian denominations were in ' 50 years of decline. ${ }^{10}$ That decline continues today.

In the 2006 national census 55.6 percent of New Zealand's population affiliated with some form of Christianity, which is down from 60.5 percent in $2001 .^{11}$ Changes to the makeup of those affiliations indicate movements away from traditional Christian

\footnotetext{
${ }^{5}$ Charles Taylor, A Secular Age (Cambridge, Mass.: Belknap Press of Harvard University Press, 2007), 3 .

${ }^{6}$ Matheson, "Myth of a Secular New Zealand," 178, 185-87; Geering, 2100, A Faith Odyssey, 8-9; Ahdar, "Reflections,” 622-32; Morris, "Who Are We?," 250;___, "Spirituality Abroad," 224; Peter Lineham, "Government Support of Churches in the Modern Era," in God and Government: The New Zealand Experience, ed. Rex Ahdar and John Stenhouse (Dunedin: University of Otago Press, 2000), 41.

${ }^{7}$ James Belich, Making Peoples: A History of the New Zealanders from Polynesian Settlement to the End of the Nineteenth Century (Auckland: Allen Lane, 1996), 438; Colin Brown, "Christianity: Mainline Denominations to the 1960s," in Religions of New Zealanders, 65, 71; Ahdar, "Reflections," 620-21.

8 James Veitch, "Christianity: Protestants Since the 1960s," in Religions of New Zealanders, 90; Geering, 2100, A Faith Odyssey, 17.

${ }^{9}$ Veitch, "Christianity: Protestants Since the 1960s," 90; Geering, 2100, A Faith Odyssey, 17, 21.

10 William James Hoverd, "No Longer a Christian Country? - Religious Demographic Change in New Zealand 1966 - 2006," New Zealand Sociology 23, no. 1 (2008): 49.

11 Statistics New Zealand, "New Zealand Religious Affiliation 2006," http://www.stats.govt.nz/Census/2006CensusHomePage/QuickStats/quickstats-about-asubject/culture-and-identity/religious-affiliation.aspx, 'Christian Religions'
} 
denominations and a rise in nominal belief. ${ }^{12}$ Recent surveys indicating only 10 to 20 percent of the population regularly attends a church service support this assessment. ${ }^{13}$ There is also evidence that most of New Zealand's traditional Christian denominations have aged congregations and are not maintaining or increasing their memberships through reproduction. ${ }^{14}$

Alongside this decline, the country's fastest growing religious affiliation is "no religion", which 34.7 percent of the population and 37.7 percent of the "European" and "New Zealander" ethnic groups professed in $2006 .{ }^{15}$ These statistics have prompted some commentators to state that participation in organised religion is increasingly the domain of subsets of New Zealand society. ${ }^{16}$ Such assessments indicate a departure from New Zealand's religious past and provide the context for my study of spiritualities of landscape in the country's present and future.

The story of Christianity in New Zealand is interesting, but there are other stories to be told by exploring different measures and scopes of belief. ${ }^{17}$ Geering asserts that New Zealand's secularity does not necessarily denote irreligiosity. ${ }^{18}$ Indeed, census results do not report what respondents mean when they profess "no religion". ${ }^{19}$ And, alongside empirical decline in Christianity, there is evidence of growing interest in New

${ }^{12}$ Hoverd, "No Longer a Christian Country?," 48-50. Hoverd notes that the preference of many Evangelicals, Born Again and Fundamentalist Christians to not note their denomination may have impacted the rise of "Christian NFD" responses.

${ }^{13}$ Stephen Opie, "Bible Engagement in New Zealand: Survey of Attitudes and Behaviour, March - June 2008," The Bible Society, 11, http://biblesociety.org.nz/mediafiles/bible-society-research2008.pdf; Matheson, "Myth of a Secular New Zealand," 183. Matheson cites surveys from 2005. The Bible Society surveyed 3388 email respondents. Opie reports that ' $15 \%$ of New Zealanders attend a church service once a week or more frequently. $20 \%$ claim to attend church once a month or more frequently.'

${ }^{14}$ William James Hoverd and Chris G. Sibley, "Religious and Denominational Diversity in New Zealand 2009," New Zealand Sociology 25, no. 2 (2010): 67, 80-81.

${ }^{15}$ Statistics New Zealand, "New Zealand Religious Affiliation 2006," 'No religion'; Morris, "Fragments of Faith," 19; Hoverd, "No Longer a Christian Country?," 48. The 2001 census figure is 29.6 percent.

16 Ahdar and Stenhouse, introduction, 9-10; Morris, "Fragments of Faith," 20; Paul Morris, “Celts, Oracles and Crystals," New Zealand Books 7, no. 3 (1997): 12.

${ }^{17}$ Donovan, "Zeal and Apathy," 180.

${ }^{18}$ Geering, 2100, A Faith Odyssey, 24.

${ }^{19}$ Hoverd, "No Longer a Christian Country?," 55. 
Age and other spiritual practices; greater religious diversity (albeit buoyed by immigration); and increasing interest in the ceremonies and myths of a deepening civil religion. ${ }^{20}$ These areas of growth support a view that New Zealand does not have 'a dearth of religion but simply our own forms of it. ${ }^{21}$

The persistence of these kinds of religion and spirituality in modern Western societies is one of the factors that prompted reformulations of secularisation theory. Since the mid-twentieth century, "classic" secularisation theory has been used as a framework for analysing and predicting the relationship of religion to modernity. ${ }^{22}$ The theory is based on the assumption that religion is less important in modern societies. ${ }^{23}$ It posits that a modern society is a secular society in which religion is privatised and in decline. ${ }^{24}$ These assumptions were increasingly challenged in the 1980s and 1990s, however, as critical observations of continued religiosity in modern Western societies gained traction and pointed to the theory's failure. ${ }^{25}$ In 1999 Peter Berger, a prominent sociologist of religion, withdrew his support for classic secularisation theory and since then it has been largely abandoned or critically revised. ${ }^{26}$ Revised theories are increasingly complex and rely on different definitions of both secularity and religion. ${ }^{27}$

Some theorists, such as José Casanova, have called for a shift in focus from

${ }^{20}$ Morris, "Fragments of Faith," 19-20;___ "Celts, Oracles and Crystals," 12; Matheson, "Myth of a Secular New Zealand," 178; Hoverd, "No Longer a Christian Country?," 47-48; Statistics New Zealand, "New Zealand Religious Affiliation 2006," 'Other Religions'; Morris, "Who Are We?," 247-48; — "Spirituality Abroad," 218-19.

${ }^{21}$ Morris, Ricketts, and Grimshaw, introduction, 10.

22 Schultz, "Secularization," 170; THR, “After Secularization,” 5; José Casanova, "The Secular and Secularisms," Social Research 76, no. 4 (Winter 2009): 1050; — , Public Religions in the Modern World (Chicago: University of Chicago Press, 1994), 211.

${ }^{23}$ Schultz, "Secularization," 171; THR, "After Secularization," 5.

${ }^{24}$ Casanova, Public Religions, 19-20, 211;_—_ "Rethinking Secularization: A Global Comparative Perspective," The Hedgehog Review 8, no. 1-2 (Spring \& Summer 2006): 7, 11; —_, “The Secular and Secularisms," 1050, 1053-54; Tahal Asad, Formations of the Secular: Christianity, Islam, Modernity (Stanford, California: Stanford University Press, 2003), 181-82; Steve Bruce, God Is Dead: Secularization in the West, Religion and Modern World (Oxford: Blackwell Publishers, 2002), 3.

${ }^{25}$ Schultz, "Secularization," 170, 174-75; THR, “After Secularization," 5.

${ }^{26}$ Peter Berger, "The Desecularization of the World: A Global Overview," in The Desecularization of the World: Resurgent Religion and World, ed. Peter Berger (Michigan: Wm. B. Eerdmans, 1999), 2; Schultz, "Secularization," 174-75; Charles T. Mathewes, "An Interview with Peter Berger," The Hedgehog Review 8, no. 1-2 (Spring \& Summer 2006): 152; THR, "After Secularization," 5; Casanova, "Rethinking Secularization," 7.

${ }^{27}$ Schultz, "Secularization," 171. 
formulating universal theories to exploring the 'multiple secularisations' as experienced in 'multiple modernities'. ${ }^{28}$ Charles Taylor offers one such account in $A$ Secular Age, his significant thesis on the emergence and phenomenological experiences of secularity in Western societies. Taylor acknowledges dominant formulations of secularization; namely, the privatisation and decline of religious practice and belief, but asserts that these measures do not adequately capture or explain the place of religion in current 'conditions of belief, by which people understand and live their lives. ${ }^{29}$

Taylor characterises a society as secular when 'belief in God is no longer axiomatic' and is often difficult to maintain. ${ }^{30}$ But he also illuminates the emergence of 'recompositions of spiritual life in new forms' and characterises the secular age as a 'spiritual super-nova' that is marked by 'an unheard of pluralism of outlooks, religious and non- and anti-religious, in which the number of possible positions seems to be increasing without end. ${ }^{31}$ Taylor's thesis is dense and, at points, flawed. ${ }^{32}$ Yet, it is instructive in articulating the complexities of belief and unbelief in Western secular societies. He dispels the dichotomy between secularity and religion, and draws attention to other scopes of belief. I draw upon elements of Taylor's alternative to an "empty" secularity in defining spiritualities focussed on landscape, as I discuss below.

\footnotetext{
${ }^{28}$ Ibid.: 176; THR, “After Secularization,” 6; Casanova, "Rethinking Secularization,” 8-9, 10-14, 17; — "The Secular and Secularisms," 1050. Others include Taylor, A Secular Age, 21; Asad, Formations of the Secular, 1.

${ }_{29}$ Taylor, A Secular Age, 1-5, 14, 427, 432, 437, 523, 594.

30 Ibid., 3, 11.

${ }^{31}$ Ibid., 300, 437, 513, 515.

${ }^{32}$ For examples of criticism see Richard Bernstein, "The Uneasy Tensions of Immanence and Transcendence," International Journal of Politics, Culture, and Society 21, no. 1-4 (December 2008); Dipesh Chakrabarty, "The Modern and the Secular in the West: An Outsider's View," Journal of the American Academy of Religion 77, no. 2 (June 2009); Paul James Crittenden, "A Secular Age: Reflections on Charles Taylor's Recent Book," Sophia 48, no. 4 (November 2009); James Miller, "What Secular Age?," International Journal of Politics, Culture, and Society 21, no. 1-4 (December 2008). Bernstein observes that Taylor's thesis relies on a very specific conception of religion. Chakrabarty criticises Taylor's ambiguity on transcendence. Crittenden criticises Taylor's narrow consideration of transcendence. Miller criticises Taylor for making generalisations that are unsupported by empirical evidence.
} 


\section{What Are Spiritualities of Landscape?}

Like religion, spirituality is difficult to define. It encompasses a broad range of beliefs, practices and ways of living, which are held inside, outside and alongside organised religion. It is sometimes conflated with the jumble of New Age beliefs, practices and paraphernalia that gained international and local visibility from the 1960s. ${ }^{33}$ Since then, "spirituality" has entered the vernacular in phrases such as "spiritual but not religious" to denote a belief in "something" beyond material reality. ${ }^{34}$ These beliefs are often vague and uncertain but tend to focus on the self and this world, emphasise feeling and are distanced from organised religion. ${ }^{35}$ David Tacey acknowledges these features by defining spirituality as 'a search for meaning in this world, as a quest for the integration of body, soul and spirit. ${ }^{36}$ He claims that by using the term, people are 'suggesting that some - not all - elements of human nature may have a transcendent dimension, and may be related to a mystery that we can only partially comprehend. ${ }^{37}$

These descriptions point to a mode of belief that is characterised by informality and individuality. I adopt a broad understanding of spirituality in recognition of these attributes. This broad understanding has the benefit of allowing the literature, rather than a strict definition, to determine spiritual themes while delimiting between secular and spiritual forms. In the rest of this section I outline the considerations that shape my understanding of spirituality, including New Zealand's secularity, Charles Taylor's idea

${ }^{33}$ David Tacey, The Spirituality Revolution: The Emergence of Contemporary Spirituality (East Sussex: Routledge, 2005), 3-4; Taylor, A Secular Age, 508, 512; Paul Heelas, The New Age Movement (Oxford: Blackwell, 1996), 1-2; Morris, "Celts, Oracles and Crystals," 12; —_, "New Zealand Spirituality: A Time for Re-Enchantment," in Spirit in a Strange Land, 186.

34 Tacey, The Spirituality Revolution, 30;

35 Paul Heelas, "Challenging Secularization Theory: The Growth Of 'New Age' Spiritualities of Life," The Hedgehog Review 8, no. 1-2 (Spring \& Summer 2006): 46-47; Danièle Hervieu-Léger, "In Search of Certainties: The Paradoxes of Religiosity in Societies of High Modernity," The Hedgehog Review 8, no. 12 (Spring \& Summer 2006): 61; Taylor, A Secular Age, 507-09; Gary D. Bouma, Australian Soul: Religion and Spirituality in the Twenty-First Century (Cambridge: Cambridge University Press, 2006), 15. 2009), 168-69.

${ }^{36}$ David Tacey, Edge of the Sacred: Jung, Psyche, Earth (Einsiedeln, Switzerland Daimon Verlag,

${ }^{37}$ Ibid., 169. 
of fullness, Thomas Luckmann's levels of transcendence, and Catherine Albanese's study of American "nature religion”. I begin with Taylor.

In $A$ Secular Age Taylor identifies the basic mode of spiritual life as 'the quest'. ${ }^{38}$ At the core of this quest he identifies a pursuit for 'fullness', which he describes as the experience or understanding of 'some way in which this life looks good, whole, proper, really being lived as it should. ${ }^{39}$ Taylor does not define fullness, instead he describes how it may be experienced and to where it may lead. He claims:

Somewhere, in some activity, or condition, lies a fullness, a richness; that is, in that place (activity or condition), life is fuller, richer, deeper, more worth while, more admirable, more what it should be. This is perhaps a place of power: we often experience this as deeply moving, as inspiring. Perhaps this sense of fullness is something we just catch glimpses of from afar off; ... But sometimes there will be moments of experienced fullness, of joy and fulfillment, where we feel ourselves there. ${ }^{40}$

Taylor claims that experiences of fullness enrich people's lives by orienting them morally or spiritually, which he asserts is necessary for 'any liveable understanding of human life, ${ }^{41}$ He identifies fullness as an element of human life that goes some way to explain the persistence and proliferation of religion and spirituality in modern societies. He states:

Every person, and every society, lives with or by some conception(s) of what human flourishing is: what constitutes a fulfilled life? what makes life really worth living? [sic] What would we most admire people for? We can't help asking these and related questions in our lives. And our struggles to answer them define the view or views that we try to live by, or between which we haver. ${ }^{42}$

While the quest for fullness does not necessarily lead to religious or spiritual outcomes it has traditionally been answered by philosophical theories, moral codes,

\footnotetext{
38 Taylor, A Secular Age, 508.

${ }^{39}$ Ibid., 600.

${ }^{40}$ Ibid., 5.

${ }^{41}$ Ibid., 6, 600.

${ }^{42}$ Ibid., 16.
} 
religion and, increasingly, by a pluralism of moral or spiritual positions. ${ }^{43}$ In this way, the quest for fullness can be understood as a broad spiritual or moral search that is unconstrained by particular belief systems, practices or ways of living. As fullness points to experiences of transcendence, fulfilment and revelation that enrich and orient life, it also aligns with a broad understanding of spirituality. ${ }^{44}$

To illustrate the power of experiences of fullness, Taylor cites Bede Griffiths' childhood experience of revelation in nature. Griffiths' experience occurred during an evening walk when he was struck by an awe for nature and, with awareness that the sky 'was but a veil before the face of God', was moved to kneel on the ground. ${ }^{45}$ Taylor's use of this example suggests that nature or landscape can be a source and focus of fullness. But here, and elsewhere, Taylor infers that some paths to fullness are more worthwhile or fulfilling than others. ${ }^{46}$

Taylor states that some spiritual seekers, dissatisfied with 'a momentary sense of wow!', will be lead to traditional religious faith via their quest to 'take it further'. ${ }^{47}$ While this contention is not problematic in itself, Taylor implies that "authentic" experiences of fullness are found within the Judeo-Christian tradition. ${ }^{48}$ For example, he proffers that some people will progress from forms of 'undemanding spirituality', such as 'a meditation group, or a prayer circle; and then later, if they move along in the appropriate direction, they will find themselves embedded in ordinary practice' (emphasis added). ${ }^{49}$ Taylor's use of the Griffiths' example is also significant, as Griffiths' transcendent experience is, crucially, a catalyst for an engagement with organised Christian practice

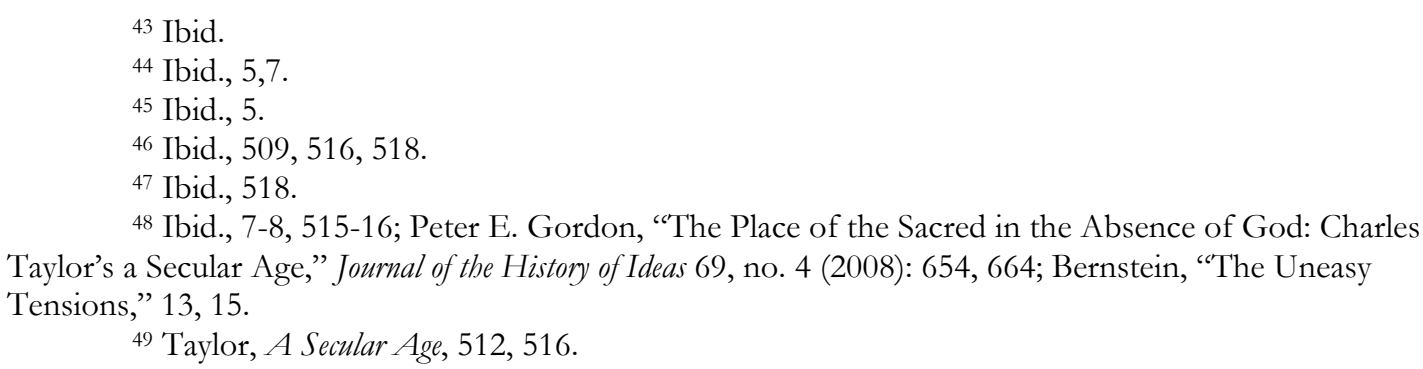


and belief..$^{50}$

Taylor acknowledges that his descriptions of fullness may appear to 'tilt towards the believer' and this tilt is further evident in his definition of religion by a belief in transcendence and his restriction of transcendence to its theistic forms. ${ }^{51}$ Taylor's articulation of fullness and inclusion of transcendence are useful measures to delimit between spiritual and secular quests. He is helpful in dispelling the view of an empty secularity, yet his narrow scope makes it apparent that I require understandings of spirituality and transcendence that are suitable for a New Zealand context. Given the flavour of New Zealand's secularity, I do not anticipate that spiritualities of landscape will predominantly orient people towards figures or locations associated with traditional forms of religion.

Thomas Luckmann's conception of transcendence provides such scope. Luckmann claims that 'experiences of transcendence are a universal component of human life. ${ }^{52}$ To explain this stance he identifies three levels of transcendence. ${ }^{53}$ His 'little' transcendence are small disruptions of time and space that can also be experienced outside of transcendent moments. ${ }^{54}$ 'Intermediate' transcendence are intangible communal experiences, such as sharing in the inner life of another person or participating in collective life. ${ }^{55}$ And, 'great' transcendence are experiences that point to something that is not and cannot be experienced within material reality. ${ }^{56}$ While such moments cannot be produced at will, Luckmann states that there are many ways they can be experienced; all of which involve the 'leaving of everyday reality behind', in moments where 'life loses its status as the preeminent reality at least for the duration of

\footnotetext{
${ }^{50}$ Ibid., 5, 14, 351, 407, 512, 769; Gordon, "The Place of the Sacred," 671; Bernstein, "The Uneasy Tensions," 14.

51 Taylor, A Secular Age, 7, 15-16, 20.

52 Thomas Luckmann, "Shrinking Transcendence, Expanding Religion?," Sociological Analysis 51, no. 2 (Summer 1990): 127.

53 Ibid.: 129.

${ }^{54}$ Ibid.

55 Ibid.: $128-30$.

56 Ibid.: 129.
} 
those experiences. ${ }^{57}$ This understanding of transcendence is more appropriate for my study, as it broadens spiritual possibilities beyond traditional forms of religion.

Finally, I take guidance from Catherine Albanese's articulation of American nature religion. In Nature Religion in America: From the Algonkian Indians to the New Age Albanese reconsiders selected religious beliefs and movements from America's past and present in a way that 'throws light on certain elements of our history that we've haphazardly, or even failed, to see religiously. ${ }^{, 58}$ She understands religion as 'the way(s) people orient themselves in the world with reference to both ordinary and extraordinary powers, meanings and values', where the ordinary is found within the boundaries of society and the extraordinary rests some place outside inviting its members across an invisible line to a place of transcendence. ${ }^{59}$ In relating this understanding to nature religion she notes that the people and movements she discusses may have 'heartily demurred' at the idea of following a 'nature religion'. ${ }^{60}$

While Albanese's project is substantially different to mine, her acknowledgement that her work is an act of construction is instructive. My articulation of spiritual landscape themes drawn from literary fiction is also an act of construction. ${ }^{61}$ I illuminate spiritual possibilities that may otherwise be obscured and are unlikely to translate into the kinds of spirituality that people outwardly subscribe to or practise. They may, but they are more likely to represent ways of living in and identifying with landscape that can be viewed through a spiritual lens.

Thus, my understanding of spirituality is shaped by New Zealand's secularity, Taylor's articulation of the secular age as 'spiritual super-nova', Thomas Luckmann's levels of transcendence and awareness that a spiritual reading of secular texts is an act of

\footnotetext{
57 Ibid.

58 Catherine Albanese, Nature Religion in America: From the Algonkian Indians to the New Age, Chicago History of American Religion (Chicago: University of Chicago Press, 1990), 7-8.

${ }^{59}$ Ibid., 6-7.

60 Ibid., 7.

${ }^{61}$ Ibid., 8.
} 
construction. ${ }^{62}$ In analysing literary representations of spirituality, I am looking at a broad grouping of spiritual beliefs, experiences and values that are focussed on landscape. Like fullness, these spiritualities will often function to enrich and orient life. They are likely to be represented as a source or focus for experiences of wonder or fulfilment, clarity or guidance, or feelings of communion, fear or joy. The spiritualities will be plural but are likely to involve transcendence, whether they are little, intermediate or great. Thus, transcendence may be this- or other-worldly; pointing to other dimensions, other people or experiences of communal life. In the next section I discuss depictions of transcendence in landscape that suggest my writers' spiritual themes and representations are shaped by New Zealand's secularity.

\section{'there's evidently something / up there'}

In Living in the Maniototo Janet Frame writes, 'The streets tell the names of the battles, but it is the literature and our imagination which tells us about those who fought. ${ }^{63}$ Within my selection of Pakeha literary fiction, many writers tell us about the experiences of belief and unbelief that are indicated by the empirical measures of New Zealand's secularity. Many do so by including religious disinterest or a rejection of organised religion as a feature of their Pakeha characters' identities. Thus, in Going West Maurice Gee's protagonist considers himself a humanist as even atheism is 'a way of sneaking God in. Original sin? He won't buy it, it revolts him. Divine? He finds the idea unpleasant. Saviour? What a human defeat. And so on. ${ }^{64}$ And, in Zoology Sheridan Keith describes an omnipotent God as an entity who 'planned everything and made everyone suffer for some spiritual point. ${ }^{65}$ Other writers do so by depicting spiritual concerns and experiences that fall outside of traditional forms of religion.

\footnotetext{
62 Taylor, A Secular Age, 300.

${ }^{63}$ Janet Frame, Living in the Maniototo (1981; repr., London: Women's Press, 1991), 41.

${ }^{64}$ Maurice Gee, Going West (Auckland: Viking, 1992), 13.

65 Sheridan Keith, Zoology (Auckland: Penguin, 1995), 76.
} 
In this section I discuss portrayals of transcendence in landscape that offer reflections of the some of the changes in religious belief and practice in New Zealand. The examples indicate that my writers' spiritual themes and the kinds of spiritualities they represent are informed by New Zealand's secularity. This secular basis resonates with the experiences of many Pakeha, which indicates that representations of spirituality in landscape articulate some of the experiences of living here. Significantly, it demonstrates the rich spiritual currents existent within New Zealand's secularity.

The flavour of New Zealand's secularity is reflected in depictions of landscape fulfilling spiritual needs or desires that are traditionally met by or associated with religious belief. For example, in Harlequin Rex Owen Marshall describes his character, David, as a person who 'never paid his dues as far as religion went'. ${ }^{66}$ Yet, David experiences 'something significantly beyond and greater than himself' in landscape, which fills him with 'a fierce joy to be alive ${ }^{97} \mathrm{He}$ feels that in these moments 'a message was given then, wasn't it? But always just out of earshot, or beyond his comprehension. ${ }^{68}$ David is disinterested in religion but treats his experiences in landscape with reverence and finds them difficult to share or express to others. ${ }^{69}$ Thus, he wonders:

How could he explain to Lucy that the fewer people he had around him, the more clearly he heard the voice of the land. How could he express the satisfaction it gave him to be quite solitary among hills. ${ }^{70}$

David's experiences are identifiably spiritual. They are fragmentary, elusive, transcendent, and elicit joy. Notably, Marshall separates them from traditional forms of religion. They lead David to a personal, spiritual connection with landscape rather than

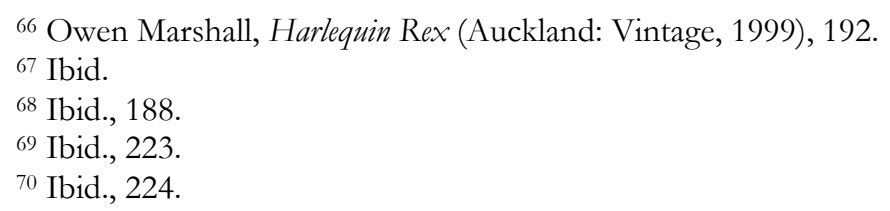


other religious or spiritual beliefs.

O.E. Middleton’s story “A Married Man” in Selected Stories shares similarities.

Middleton portrays a moment of transcendence in landscape that fulfils a spiritual need that is traditionally met by religious ceremony. He depicts a young father, Tony, burying his newborn son alone. In describing Tony's uncertainty over how to adequately solemnise the burial, Middleton describes Tony's exposure to and subsequent abandonment of Christian belief. He states that Tony,

did not believe in a god. The scraps of religion and Bible history which had stayed with him from Bible class and Sunday school days had long since ceased to have any meaning. ${ }^{71}$

Thus, when Tony recites the Lord's Prayer he feels reverence but his spiritual and emotional needs are not met. But as he looks across the bay from a coastal hill, the landscape provides reassurance and orientation. In a moment of transcendence, Tony realises that he is not alone in his experience, as others must have stood on the same ground processing the same grief while 'searching the landscape for a sign, an omen, anything to reassure them. ${ }^{, 72}$ Like Marshall, Middleton contrasts the enrichment and orientation gained from landscape with disinterest in traditional forms of religion. Tony's experience is solitary and self-contained. It meets a spiritual need but, again, there is no suggestion that it catalyses interest or participation in other spiritual or religious forms.

The influence of New Zealand's secularity is further reflected in the prevalence of references to vague transcendent forces, figures and locations. While some writers use Christian vocabularies, which I discuss shortly, most do not. Their choices of spiritual terms rather than figures and locations associated with particular religious

\footnotetext{
1975), 148 .

${ }^{71}$ O.E. Middleton, “A Married Man,” in Middleton, Selected Stories (Dunedin: John McIndoe, ${ }^{72}$ Ibid.
} 
traditions resonate with the decline in traditional religious belief and practice in $\mathrm{New}$ Zealand. The variety and richness conveyed in their representations is suggestive of enduring spiritual experience and expression.

To demonstrate, in Ladders of Rain and Beyond Brian Turner uses a spiritual vocabulary to elevate landscapes from physical environments to 'a place as close to Paradise / as any left on earth. ${ }^{73}$ In "Graduation" in Ladders of Rain he writes, "All the spaces under us, / not quite empty, ever' and in "Watch for the Ice" he asserts that the earth is 'But very much alive, / as we are alive .. .74 In these poems Turner locates something transcendent in landscape but does not name or otherwise identify it. In "Pastoral" he does name a presence, as he exhorts the reader to 'face up to that Spirit / and the earth'. ${ }^{75}$ He subordinates himself to both by identifying landscape and the spirit as something,

To which I am dumb and which cannot speak the language of fools ${ }^{76}$

In these examples Turner's landscapes are alive and interactive. His subordination to 'that Spirit' connotes reverence for a greater, spiritual force. His identifications of something greater within the landscape and the earth are assertions rather than suggestions, yet the forces he represents are ambiguous and unnamed.

Other writers portray landscape as a conduit for an ambiguous spirit or transcendent force. For example, in "The Weather in Tohunga Crescent" in You Will Know When You Get There: Poems 1979-81 Allen Curnow locates a spirit in the wind. His poem describes an uncharacteristically calm day in which the absence of a coastal breeze

\footnotetext{
${ }^{73}$ Brian Turner, "In the Nineties," in Turner, Beyond (Dunedin: McIndoe, 1992), 8.

74 __. "Pastoral," in Turner, Ladders of Rain (Dunedin: John McIndoe, 1978), 41; "Graduation," in Turner, Ladders of Rain, 26; __ "Watch for the Ice," in Turner, Ladders of Rain, 60. 75 , "Pastoral," 41.

${ }^{76}$ Ibid.
} 
arrests life and makes it strange, as 'the bay at the bottom / of the street has been glassy a moment / too long..${ }^{, 77}$ Curnow connects the wind with inspiration to write, as without it,

$$
\text { your finger }
$$

pricks as if it might but won't be lifted for something... ${ }^{78}$

As the poem continues, Curnow describes giving up writing to go indoors. He concludes:

the wind bloweth as it listeth or listeth not there's evidently something up there and the thing is the spirit ${ }^{79}$

In this poem the wind carries or is an indication of a vague spiritual force that is described as 'something', a 'thing' and 'the spirit'. Unlike Turner's assertions, Curnow's identification of something in or beyond the landscape is less certain, as he arrives at his conclusion via deduction. Yet, he too subordinates himself to landscape, as the wind harbours necessary inspiration and chooses to 'listeth or listeth / not'. ${ }^{80}$ The transcendent forces in Curnow's landscape enrich and orient life as they provide inspiration and a sense of continuity without which life feels strange. And, like Turner, Curnow's representation of a transcendent force is ambiguous and unnamed.

Curnow's depiction of landscape as a point of contact with spiritual forces is repeated in other works. For instance, in The Shag Incident Stephanie Johnson's character describes his sense of communion with 'some great beak in the sky' that makes him aware that 'nothing will ever be the same the again, at least as far as freedom and love

77 Allen Curnow, "The Weather in Tohunga Crescent," in Curnow, You Will Know When You Get There: Poems 1979-81 (Auckland: Auckland University Press / Oxford University Press, 1982), 13.

${ }^{78}$ Ibid., 14.

${ }^{79}$ Ibid., 15.

${ }^{80}$ Ibid. 
are concerned. ${ }^{81}$ In another scene he describes his understanding of an afterlife as a 'vast tumbling ocean' rather than a heaven or hell. ${ }^{82}$ In these and other scenes Johnson represents landscape as a site for communion with transcendent forces, in moments that inspire feelings of comfort and guidance. In Dead Sea Fruit Charlotte Randall's character also identifies a coastal landscape as a site for connection with something greater than himself. He describes the strange feeling he gets that deserted beaches are a personal gift from 'someone infinitely benevolent'. ${ }^{83}$ His solitary experiences on the coast enrich and orient him, as they provide him with glimpses of how he would like his life to be. ${ }^{84}$

The examples I have given thus far convey a distance between spiritual thoughts and feelings focussed on landscape and other, structured, forms of belief. Yet, landscape is also represented as a point of connection with prior spiritual or religious encounters. For example, in "9 x 14 - The Yellow Sonnets (4)" in Quesada, Poems: 197274 C.K. Stead represents landscape as a source and a reminder of transcendence. He describes looking over an urban scene that seems sculpted, which prompts him to muse on a grand design that flows through nature and himself. ${ }^{85}$ In "9 x 14 - The Yellow Sonnets (1)" he suggests this kind of knowing is gained from an experience of great transcendence. He does not identify where the transcendence took place but he is reminded of it by flowering kowhai, which he describes as, 'As if someone had called on the faithful to each light a candle'. ${ }^{86}$

Yet, Stead's poem is tinged with darkness rather than light, as he hints at a somber side to spiritual experience. He compares waiting for kowhai to blossom with

\footnotetext{
${ }^{81}$ Stephanie Johnson, The Shag Incident (Auckland: Vintage, 2002), 28.

82 Ibid.

${ }^{83}$ Charlotte Randall, Dead Sea Fruit (Auckland: Secker \& Warburg / Reed Books, 1995), 260-61.

${ }^{84}$ Ibid.

${ }^{85}$ C.K. Stead, "9 X 14 - the Yellow Sonnets (4)," lines 1-9, in Stead, Quesada: Poems, 1972-74

86 _ "9 X 14 - the Yellow Sonnets (1)," in Stead, Quesada, 35.
} (Auckland: The Shed, 1975), 36-37. 
waiting to re-experience transcendence, claiming, 'I know the darkness / These flowers make known, $\ldots{ }^{87}$ Here, landscape colours life by serving as a reminder of the presence and subsequent absence of 'An ecstasy of which each moment after of life / harbours an echo ... ${ }^{88}$ Again, the writer's choice of an ambiguous spiritual vocabulary distinguishes this spiritual landscape from traditional forms of religion. Stead makes this distance even clearer when he writes, 'The quarrel of sparrows / Fills the silence of God that has lasted for forty-two years. ${ }^{, 89}$

While the examples I have given thus far depict people finding in landscape the kinds of fulfilment and orientation that are traditionally associated with religious belief, my primary sources also contain indications of the social and cultural influence of Christianity in New Zealand. To demonstrate, in " $1{ }^{\text {st }}$ September, 1974" in Quesada Stead identifies the sea as the path for spirits of the dead to 'Stream northward to their home. ${ }^{90}$ In "Wellington Letter (XVI)" in Selected Poems Lauris Edmond also identifies landscape as a path to heaven, as she describes the grandeur of New Zealand landscapes as 'the sweep from earth / to heaven, the mind soaring ten thousand / feet in an instant; .. . ${ }^{91}$ In "September" she again associates landscape with Christian referents, writing, 'I shall learn the lessons of God / from the mountain ...92

These examples position landscape as a conduit for religious, and specifically Christian, figures, values and locations. Beyond the personal beliefs of individual writers, they demonstrate Christianity's social and cultural penetration in New Zealand. Neither Stead nor Edmond write religious verse, yet the social currency of Christian vocabularies provides them with a language with which to express spiritual and religious

\footnotetext{
${ }^{87}$ Ibid.

88 Ibid.

89 _- "9 X 14 - the Yellow Sonnets (6)," in Stead, Quesada, 38.

90 - "1 "1st September, 1974," in Stead, Quesada, 26.

${ }^{91}$ Lauris Edmond, "Wellington Letter (XVI)," in Edmond, Selected Poems (Auckland: Oxford

92 _ "September," in Edmond, Selected Poems, 123.
} University Press, 1984), 54. 
feeling. The examples also indicate that spiritualities of landscape coexist with other forms of belief. Some writers blend spiritual and Christian vocabularies to describe transcendence in landscape. For example, Cilla McQueen ends her poem "A Walk on the Hill" in Homing In with the word 'litany'. ${ }^{93}$ This word suits her listing of natural elements, associates landscape with religious practice, and contributes to her elevation of landscape from a physical terrain to a place of personal, spiritual meaning.

The examples I have discussed in this section portray moments of transcendence in landscape that fulfil spiritual needs and desires, and enrich and orient lives. In this way, they echo one of Charles Taylor's descriptions of fullness, as moments that 'can orient us because they offer some sense of what they are of: the presence of God, or the voice of nature, or the force which flows through everything. ${ }^{94}$ The wealth of spiritual expression and representation illuminates the spiritual possibilities that lie outside of traditional forms of religion. The examples convey the belief and feeling that, as Curnow writes, 'there's evidently something / up there'. ${ }^{95}$ Yet, the reflections of New Zealand's conditions of belief indicate that the writers' spiritual themes and representations are informed by and borne from New Zealand's secularity.

Thus, the examples are not depictions of New Age or pagan "nature spiritualities". They are not indicative of a spiritual revival. Nor do they herald a turn to a religious past or future. The examples by Marshall and Middleton, and the prevalence of ambiguous forces and figures, signal a distance from traditional forms of religion. Yet, as indicated by Stead, Edmond and McQueen, such spiritual feelings and experiences are not necessarily in opposition to other forms of belief. These features give shape to representations of spirituality and landscape that are constructed within the context of this country's secularity. This secular basis is significant, as it signals a

\footnotetext{
1982), 27.

${ }^{93}$ Cilla McQueen, “A Walk on the Hill,” in McQueen, Homing In (Dunedin: John McIndoe,

94 Taylor, A Secular Age, 6.

${ }^{95}$ Curnow, "The Weather in Tohunga Crescent," 15.
} 
consideration of spirituality and landscape within a New Zealand context. In the next chapter I demonstrate how my writers convey the importance of landscape to identity. 


\section{CHAPTER THREE}

\section{BELONGING BY BEING AT HOME}

In The Oxford History of New Zealand Literature in English MacDonald P. Jackson highlights that 'a poet likes to work with materials that lie to hand'. ${ }^{1}$ He claims, 'For a New Zealander these will inevitably include local flora, fauna, scenes, institutions, people, events, myths, practices and habits of mind, along with much that is available to poets everywhere. ${ }^{2}$ It is, therefore, unsurprising that representations of identifiably New Zealand landscapes pervade Pakeha literary fiction. In this chapter I discuss the landscapes represented as sites for spirituality within my primary sources. I identify a local focus that conveys the importance of landscape to identity and suggests that many Pakeha explore and express themselves in relationships with landscape.

I begin with examples of spiritualities of landscape represented by four Pakeha writers in six literary works. From these examples I identify common themes of belonging and home, which I explore further in the rest of the chapter. I demonstrate that spiritualities of landscape articulate feelings of being "at home". Expressions of the necessity and reward gained from relationships with landscape ground assertions of belonging. As I demonstrate in the last section of the chapter, the local focus is suggestive of developments in literary themes, which have resonance with changes in the ways Pakeha are living in and identifying with landscape.

\section{Part One: Spiritualities of Landscape in Pakeha Literary Fiction}

In this part of the chapter I introduce the spiritualities of landscape portrayed by

\footnotetext{
1 Alistair Campbell, response to "A Survey”, Landfall 122 (June 1970) quoted in MacD. P. Jackson, "Poetry, Part One: Beginnings to 1945," in The Oxford History of New Zealand Literature in English, 402.

2 MacD. P. Jackson, "Poetry, Part One: Beginnings to 1945," in The Oxford History of New Zealand Literature in English, 402.
} 
Cilla McQueen, Lauris Edmond, Damien Wilkins and Anne Kennedy. The writers' texts span my time frame. They depict different landscapes, experiences of transcendence and expressions of reverence. They use spiritual vocabularies or depict landscape in ways that may be recast in a spiritual light. While their points of departure illustrate the diversity of spiritual and landscape themes, the four writers are united in articulating relationships between landscape, spirituality and identity. From their prose and poetry I identify common themes of belonging and home, which they share with other examples given later in the chapter. These themes convey the importance of landscape to identity. I begin with poetry by Cilla McQueen.

In "Words Fail Me" in Homing In McQueen describes a view from coastal hills as 'a continually moving / picture show', but her expressions of reverence suggest that landscape is more than an entertaining or pretty scene. ${ }^{3}$ The poem depicts a landscape that demands and eludes capture. McQueen writes of abandoning poetry to draw, 'to put into line what / the words are not fluid enough for. ${ }^{4}$ In this and other poems, McQueen describes moments of transcendence in landscape, as she evokes communion by immersing herself in the scene. Yet, rather than shock or confusion, McQueen imbues such moments with quietude and suggests they recur. ${ }^{5}$ For example, in "Low Tide, Aramoana" she describes an experience of communion in a coastal landscape. She writes:

${ }^{3}$ Cilla McQueen, "Words Fail Me," in McQueen, Homing In, 42.

${ }^{4}$ Ibid.

5 __ , "Rock Poem, Carey's Bay," in McQueen, Homing In. McQueen infers transcendence is a recurrent experience as she calls 'Times like these' moments of 'balancing at the interface, tiptoe on / a point between the world \& dream.' 
Low.

and

there's a sudden

wait

for the moment

of precise

solstice: the whole sea

hills and sky

wait

and everything

stops.

high gulls hang seaweed is arrested the water's skin tightens we all stand still. even the wind evaporates leaving a scent of salt

In this scene a walk on a beach is halted by a rupture, a leaving of everyday reality behind', as the sea, hills, sky and the poet collectively pause and exist as one. ${ }^{7}$ The changes observed in landscape are minute. The experience is 'sudden', fleeting and likely to be missed by a casual observer. Once it passes, the walk along the beach regains its 'status as the preeminent reality'. McQueen creates a similar scene in "Hoopers Inlet" in Benzina in which she describes a lake scene where a moment of stillness is broken by a heron emerging from the water. ${ }^{9}$ Like the allusion to the landscape momentarily inhaling then exhaling in "Low Tide, Aramoana", the beating of the heron's wings infers a recommencement of time. The nonchalance of McQueen's lines, such as 'I snap out back get moving before the new tide ...', suggests these experiences are a valued

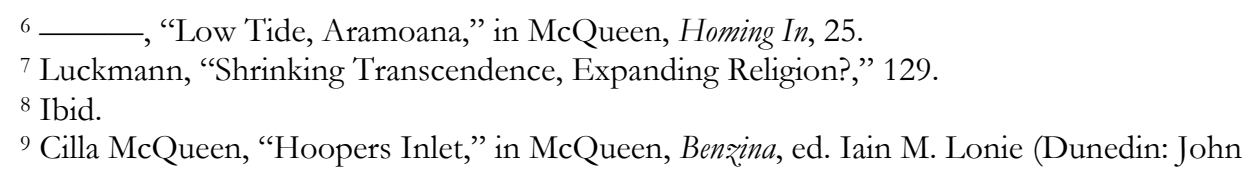


but familiar fragment of a life lived in concert with landscape. ${ }^{10}$

While McQueen's poetry conveys familiarity, her portrayals of a personal relationship with landscape are far from mundane. Her depictions of transcendence cast the landscape as a path to other dimensions, a focus for spiritual desires and an anchor for an identity that is shaped by being and belonging at home. McQueen's intimations of domesticity reinforce a relationship between landscape and belonging. Landscape is not depicted as a place to visit or a backdrop to life; it is as familiar as the back garden and it is where McQueen belongs. Thus, as she immerses herself in landscape she also draws landscape in close.

To illustrate, in "Yes Evening is a Nice Time Full of Promises" in Homing In McQueen blends the surrounding landscape with a domestic scene. This poem conveys a desire for communion that is realised while overlooking a garden, yet there is fluidity between the house, garden and the coast. McQueen writes:

but there are

moments too like these in gardens, or on beaches, when the sand stretches

out at low tide and you spread silently with it, and its tongue tickles your feet first, and all you want to do is run or fly with the birds in all the ways

they do ... ${ }^{11}$

The urge to 'fly with the birds in all the ways // they do' directs a transcendental desire into a landscape that is personified, as 'its tongue tickles your feet'. These lines bring the coastal landscape alive and into domestic life. Both the garden and coast are central to feeling at home.

McQueen's portrayals of reverence and transcendence point to a relationship

${ }^{10}$ McQueen, "Low Tide, Aramoana," 25.

${ }^{11}$ Cilla McQueen, "Yes Evening Is a Nice Time Full of Promises," in McQueen, Homing In, 21. 
with landscape that enriches and orients life. The influence this relationship has in shaping identity is apparent in poems set outside of Aramoana and New Zealand. For example, in "Weather Poem, Sydney" McQueen compares the weather in Australia with that at home, claiming the harsh coastal weather may be tough on the 'fools who / suffer it,' but 'Not to have harshness / is to have / a dimension missing., ${ }^{, 12}$ She describes Sydney's warmth as appealing but uninspiring, as a 'sky without threat / or particular promise,' prompts a pedestrian account of the weather. ${ }^{13}$ It is only when she recalls the beach at Aramoana, where the wind leaves your 'skull / clean as the inside / of an egg,' that she conveys richness and feeling. ${ }^{14}$ Berlin Diary has less of a landscape focus than Homing In or Benzina, as it is the product of time spent in Germany.

However, here too, McQueen describes experiences of transcendence in which visions of familiar landscapes link her to her sense of herself and home. ${ }^{15}$

Lauris Edmond's poetry in Selected Poems shares McQueen's themes of identity, domesticity and home. But where McQueen inscribes and unfolds her sense of herself in landscape, Edmond looks to landscape and sees herself reflected. Many of Edmond's poems articulate matters of grief. In some poems she projects her feelings of sorrow, love and acceptance onto her immediate surroundings. For instance, in "The Beech Tree" she compares the exposed rings of a fallen tree to the highs and lows that shape identities and lives, as they 'accumulate till every season of / the heart's engrained within us. ${ }^{, 16}$ The fallen tree causes Edmond to realise that no person, moment or event ever really leaves. In “The Pear Tree” Edmond's garden reminds her of a period of hopelessness and sorrow. She compares her feelings after the death of a loved one to the pear tree in winter, 'its bare branches entwined in the hieroglyphics / of a message

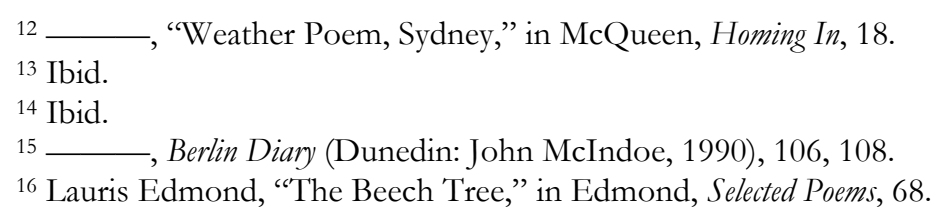


too hard for us to comprehend. ${ }^{17}$ In these poems Edmond draws her garden into her inner life as a repository for memory, a source of comfort and a place to escape the human drama that takes place within the home.

Edmond also seeks refuge in landscapes beyond her garden. For instance, in "Moonshine Valley" she looks beyond the harbour to the Rimutaka Range in search of respite. She calls to the wild grasses to provide her with protection from grief, asking them to,

hide me an hour or so from the world's sickness, drown its cries with your resonant harmonies ${ }^{18}$

Although it is beyond her garden, the Rimutaka Range is still a part of home. It sits across the harbour and is within Edmond's everyday experience. She conveys her familiarity with it, as she states a desire for transcendence. She writes, 'Wild grasses I know you, let me come in. ${ }^{19}$

In other poems landscape provides respite by rupturing moments of grief or anger. To demonstrate, in "Turning the Pear Tree to Paper" a change in weather prompts a change in emotion. Edmond depicts a storm rolling into Wellington's harbour as a source of release from ennui, as light on the walls stares without expression. ${ }^{, 20}$ She describes the change in weather as, 'But a great silent horseman lifting his hooves comes riding / across the sky; we tremble, and are saved by our fear. ${ }^{21}$ This confluence of weather and emotion is repeated in other poems, such as "Pancake for Breakfast" in which the sight of a morning mist across the harbour breaks a personal

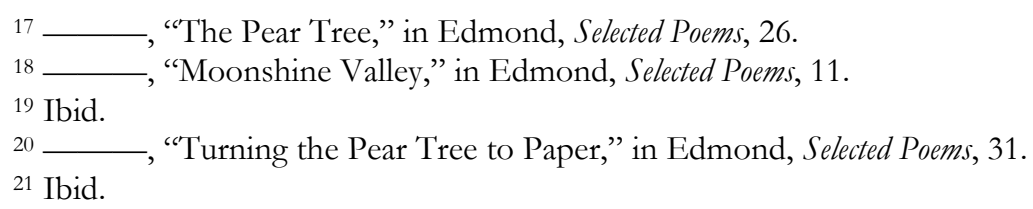


fog. ${ }^{22}$

Like McQueen, the influence landscape has on Edmond's sense of herself is evident in some of her poems that are set overseas. Some poems convey an attachment to New Zealand landscapes. For example, in "Moreporks in Menton" Edmond expresses a sense of disjunction in the 'disconsolate dark' of her temporary home in France. ${ }^{23}$ She describes an imagined morepork call, which 'belongs no more than I', that brings her closer to comfort. She writes, 'I am less a stranger for hearing the sly / and crafty Immortals in a morepork's cry. ${ }^{24}$ In this poem, domesticating the landscape and imagining New Zealand's native fauna connects Edmond with home.

Her poem, "Jardin des Colombières", provides another example, as Edmond conveys unfamiliarity and discomfort with foreign experiences of landscape. The poem begins by describing a paid-entry garden in France. The walled garden is idyllic, as an 'authentic fairyland'. ${ }^{25}$ Edmond identifies her European heritage, stating, 'I am the child of exiles who dreamt / of the lost garden. ... ${ }^{26}$ It should follow that this garden, as the country of childhood', is the embodiment of her ancestors' ideal, however, Edmond expresses detachment rather than homecoming. ${ }^{27}$ The interaction with landscape lacks domesticity. She expresses alienation, writing, 'Here it is earth / and boundaries - it is property. ${ }^{28}$ The poem suggests that Edmond's familiar experience of accessible landscape has shaped her understanding of how to live in and identify with it. Although the entry ticket is only six francs, she writes, 'the other, more / melancholy, cost I do not know. ${ }^{29}$

Damien Wilkins' novel, The Miserables, provides another example of spirituality

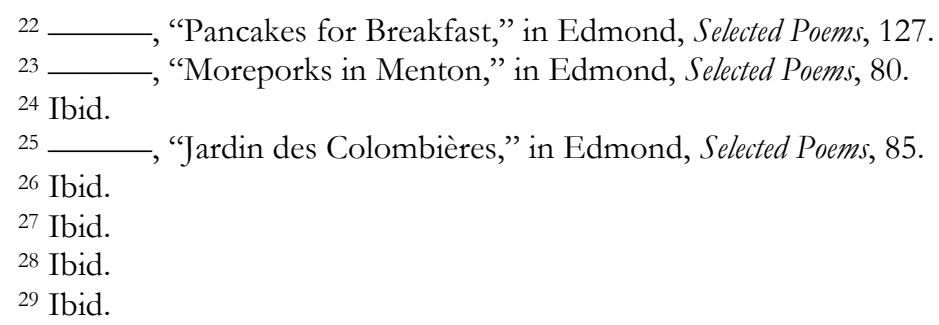


in landscape. At the beginning of the novel Wilkins' protagonist, Brett Healey, returns to Wellington for a family funeral. As he enters the harbour by ferry he is struck by the depth of feeling he has for his old home. He finds that 'something in the approach to Wellington required privacy, silence. ${ }^{30}$ The significance of the moment is conveyed in Healey's desire and inability to adequately convey his experience to his wife. Wilkins writes:

He wanted to tell her about sailing into the harbour that morning. It was somehow important that she know exactly what this moment had meant to him and that he should find a language which was not technical, or brash, or pushy, which had no trace of the Nelson architect who had stood beside him on the ferry. ${ }^{31}$

After trying and failing, Healey chooses to keep the moment to himself, echoing the confusion that often accompanies transcendent encounters. Although the experience is momentary, Healey's realisation of his attachment to Wellington reawakens him to his past and marks the beginning of a re-evaluation of his life. ${ }^{32}$ He sees both Wellington and his new Christchurch home differently, as he becomes aware of all Wellington holds and Christchurch lacks. The landscape, the weather and the sense of feeling he gets from being there are not the same. ${ }^{33}$ Wilkins writes:

None of this seeing, he thought, had been possible before he had shifted with Louise to Christchurch and begun living on the directionless Canterbury Plains. There, in that South Island city, as people had told him he would, Healey got lost. $^{34}$

Here, the reference to Healey getting lost relates to his unfamiliarity with Christchurch's streets and alludes to his loss of his sense of himself, which he regains in Wellington. It also contributes to the novel's themes of edges and design, which draw

\footnotetext{
${ }^{30}$ Damien Wilkins, The Miserables (Wellington: Victoria University Press, 1993), 50.

${ }^{31}$ Ibid., 137-38.

32 Ibid., 52.

33 Ibid., 52, 123-24.

${ }^{34}$ Ibid., 52.
} 
together the particularities of New Zealand landscapes with personal and cultural responses to the land. ${ }^{35}$ Thus, Wellington's wind creates a Wellingtonian walk, Healey's mother lives in preparation for earthquakes and New Zealanders are defined by a coast they cannot avoid. ${ }^{36}$ Not only does Wilkins' Wellington landscape dictate how people inhabit it, it is force that shapes and reshapes their identities. Ostensibly, Wilkins' novel is not about landscape but the presence and role he gives landscape elevates it from a setting to an active participant in human drama. For Healey, Wellington is home as it defines where he has come from, the person he is and may become.

My final example in this section is drawn from Anne Kennedy's Sing Song. Kennedy's collection of poetry is written from the perspective of "the mother" and is presented in chronological order. Like Wilkins' novel, some of Kennedy's poems articulate how experiences in landscape may alter how people see themselves. Landscape is not a major theme in Kennedy's collection, yet in "Whenua (1)" and "Whenua (2)" Kennedy suggests the mother arrives at a new understanding of landscape through her experiences of a Maori custom. By engaging with landscape in a different way the mother creates a bond between a particular place, her daughter and herself.

In "Whenua (1)" the mother and her Maori husband decide to bury their daughter's whenua ("placenta") by a waterfall near Karekare rather than with the husband's whenua 'Up North in silent ground, ${ }^{37}$ They are moved to bury it on the coast near their Auckland home rather than 'Up There' on family land, as the husband thinks it is anchoring them to the house they want to sell. ${ }^{38}$ During the burial they tie this 'waterfall and its lovely pool' to the husband's land by planting 'a cabbage tree from Up

35 Ibid., 49, 50, 52-53, 173, 230-33.

36 Ibid., 52, 123-24.

${ }^{37}$ Anne Kennedy, "Whenua (1)," in Kennedy, Sing Song (Auckland: Auckland University Press, 2003), 25. 'Whenua' also translates to 'land, country' and 'ground'.

38 Ibid. 
North on top - / karakia, waiata then dusk began to fall. ${ }^{39}$ Despite this connection to sacred and familiar ground, the mother worries. As the fading light cuts the ceremony short and the couple rush from the bush, the mother thinks about this part of her daughter and herself that is left alone. As the mother leaves, however, she arrives at a new understanding of place. Kennedy writes:

The mother fretted a bit about the girl's whenua left there in the dark, in the lonely beautiful place, and understood for the first time place isn't prettiness, isn't a tinkling waterfall ${ }^{40}$

Kennedy's use of 'prettiness' and 'a tinkling waterfall' infers a shift in perspective from viewing certain landscapes as picturesque to feeling bound to a particular place. This shift in feeling is reinforced by Kennedy's change of tone in "Whenua (2)". In this poem the mother returns to the waterfall 'expecting / nothing, no tree, the weedy, neglected / Friday dusk ceremony. ${ }^{41}$ Instead, she finds the cabbage tree, 'her tree', standing tall and 'unaware of its perfection. ${ }^{, 42}$ Where the descriptions of landscape in "Whenua (1)" are tinged with darkness, the same landscape is now infused with beauty and light. Kennedy describes the second encounter as,

It's a beautiful day the waterfall, its pool of glass breaking and breaking like the bush burning but still extant, still there, and there is her tree. The cabbage tree. ${ }^{43}$

The particular tree and landscape have become part of the daughter and the family; they are bound as one. As such, a landscape that was chosen for its prettiness now shares in the reverence granted to the husband's family land, which Kennedy refers

\footnotetext{
${ }^{39}$ Ibid., 25, 26.

40 Ibid., 26.

${ }^{41}$ _. "Whenua (2)," in Kennedy, Sing Song, 123.

42 Ibid.

${ }^{43}$ Ibid.
} 
to as 'Up North' and 'Up There' in "Whenua (1)". ${ }^{44}$ In this poetry neither landscape nor spirituality are central topics but these spiritual fragments are neatly suggestive of an interaction with spiritualities of landscape in everyday life. The role Maori custom plays in transforming the mother's perspective also provides a glimpse of the influence other cultures' beliefs and practices have on Pakeha constructions of landscape.

The landscapes depicted by McQueen, Edmond, Wilkins and Kennedy are different; their portrayals of transcendence, reverence, orientation and enrichment are not the same. Of the four writers, McQueen's poetry has the clearest landscape focus. Her landscape scenes are mostly local, coastal and unpeopled. Yet, rather than romanticism, McQueen's “empty” landscapes strengthen the sense of intimacy between person and place. Her depictions of transcendence point to other dimensions and, ultimately, lead McQueen back to herself. She articulates a relationship between landscape and identity that is borne from being and belonging at home.

Edmond's poetry contains more references to generic natural elements than the other three writers. However, her garden and harbour landscapes pervade her poetry, as she imbues both with personal and spiritual meaning. She depicts moments of transcendence in landscape that transport her to places of memory, communion with people she loves, and forces that exist inside and outside of this world. Like McQueen, Edmond's poetry articulates a relationship with a domesticated landscape that reflects and refracts her self-understanding and the events that shape her identity.

Both Wilkins and Kennedy illustrate that representations of spirituality in landscape are not confined to literary fiction with a landscape focus. Wilkins' spiritual landscape is constructed within a larger narrative. Unlike the domesticity conveyed by McQueen and Edmond, Wilkins' protagonist realises his attachment to a particular landscape through distance and homecoming. He does not search landscape for

\footnotetext{
${ }^{44}$ Kennedy, "Whenua (1)," 25-26.
} 
meaning or draw the landscape into himself, but in a moment of transcendence he realises how Wellington has shaped him, which helps him to reconnect with his sense of himself. Kennedy's poems portray the establishment of an attachment to landscape, as the mother's perspective is transformed by the bond she creates between her daughter and a particular place. Kennedy's poems infer that a sense of belonging changes the way people see landscape and themselves.

The four writers are united in articulating relationships between landscape, spirituality and identity. Their depictions of lives inscribed, reflected and transformed in local scenes establish landscape as a focus for identity. It is drawn into explorations and expressions of how people see themselves, their experiences and each other. The writers convey how belonging in landscape can change the way people see landscape and themselves. The landscapes they depict are mostly local and coastal; they are images of home. They are familiar and domesticated, as the writers variously portray identification with place. The spiritualities represented in these landscapes convey feelings of belonging that develop from being at home.

In the sections that follow I broaden my scope to a greater number of works. I expand on the themes of belonging and home by demonstrating the predominantly local focus of representations of spirituality in landscape. They are not spiritualities of the suburbs, but the spiritualities I discuss are located in the areas that frame the places many Pakeha live and play. This local focus and the expressions of belonging within these landscapes convey the importance of landscape to identity. I begin by discussing the sea and coast as a significant spiritual frontier.

\section{Part Two: Spirituality At Home}

\section{'We know they live in dreams along the coast'}

As Allen Curnow observed in the 1960 Penguin Book of New Zealand Verse, 'hardly 
a New Zealand poet has not been teased into inventiveness by the sea: no other people in the world is so surrounded by ocean immensities. ${ }^{, 45}$ In the examples I gave in the last section, coastal scenes in and around Aramoana pervaded Cilla McQueen's poetry, punctuated the human drama in Damien Wilkins' The Miserables and provided a source of reflection for Lauris Edmond. Many of my writers join these three in depicting New Zealand's sea and coast as sites for spiritual experience and expression. The predominance of coastal imagery reflects its spiritual potency, as the perpetual action of the coast provides a powerful motif for themes such as connection, disconnection and journey, which are particularly relevant to an immigrant, island nation. ${ }^{46}$ It follows literary trends, as the sea and coast are significant landscapes in Pakeha literary fiction. ${ }^{47}$ And, it resonates with the centrality of coastal landscapes in New Zealand's island lives. I discuss these threads below.

Within my sources, the sea and coast inspire spiritual expressions that range from inspiration to fear in scenes that reflect both the beauty and harshness of New Zealand's coastal landscape. Thus, some writers draw on the action of the coast to connote feelings of renewal and clarity. For example, in The Word Burners Beryl Fletcher associates the sea with rejuvenation, as her character recalls her wish for sea water carrying 'special powers' to overwhelm and cleanse her town. ${ }^{48}$ And, in The Shag Incident Stephanie Johnson identifies the coast as a source of power and a site for connection with other dimensions, as her exiled character claims, 'It's as if that little line of coast and ocean is a powerful spot on the globe for me. Big things happen there. ${ }^{, 49}$

In other works the action of the coast is portrayed as overwhelming. It is sometimes represented as terrifying, such as in Catherine Chidgey's In a Fishbone Church,

\footnotetext{
${ }^{45}$ Curnow, ed. Penguin Book of New Zealand Verse, 60-61.

${ }^{46}$ Caffin, "Poetry, Part Two," 504.

${ }^{47}$ Ibid.

${ }^{48}$ Fletcher, The Word Burners, 185.

${ }^{49}$ Johnson, The Shag Incident, 28.
} 
where the extremity of Wellington's harbour and the underlying threat suggested by fault lines stuns a character and renders her dumb. ${ }^{50}$ The proximity of 'the sea, the green, the trees, the sea, the sea' consumes her mind, as the landscape and an awareness of its might 'swallows her, occupies her'. ${ }^{51}$ John Cranna also depicts an overwhelming experience in a coastal scene. In "Archaeology" in Visitors he portrays an experience of transcendence on a remote beach as a moment of revelation, as the sight of a swarm of jellyfish stuns two young men who stand on the shore in awe. ${ }^{52}$ The moment obscures all other thoughts and briefly halts time. ${ }^{53}$ The experience enriches and orients the men's lives by connecting them to each other, the landscape and something beyond.

More than overwhelming, some writers create coastal scenes that evoke instability and fear. For instance, in The Skinny Louie Book Fiona Farrell describes the coast as a site of struggle. She extends an atmosphere of instability and pretence to a spiritualised sea that threatens, consumes and demands 'propitiation'. ${ }^{54}$ Sensing the threat, the town turns its back on the sea but its façade of stability is interrupted as the sea snatches back pockets of land.$^{55}$ Janet Frame creates a similar, sinister image in The Carpathians when she describes an unclosing 'eyelid of the watching sea' that follows the land's inhabitants. ${ }^{56}$ The sea responds with anger when its surveillance is thwarted. ${ }^{57}$

Somewhat less fantastically, Allen Curnow reflects on the power of the sea in "Dialogue With Four Rocks" in You Will Know When You Get There. He describes heavy seas exposing 'a / reef the size of a visiting beast' along the beach.$^{58} \mathrm{He}$ asserts that

\footnotetext{
${ }^{50}$ Catherine Chidgey, In a Fishbone Church (Wellington: Victoria University Press, 1998), 234.

51 Ibid.

${ }^{52}$ John Cranna, "Archaeology," in Cranna, Visitors, Pacific Writers Series (Auckland: Heinemann
} Reed, 1989), 64.

${ }^{53}$ Ibid.

${ }^{54}$ Fiona Farrell, The Skinny Lonie Book (Auckland: Penguin, 1992), 9.

55 Ibid.

${ }^{56}$ Janet Frame, The Carpathians (1988; repr., Auckland: Vintage, 2005), 126-27.

${ }^{57}$ Ibid. 43.

58 Allen Curnow, "Dialogue with Four Rocks," in Curnow, You Will Know When You Get There, 
'little / as you like to think nothing's either / covered or uncovered for ever. ${ }^{59}$ Despite this assertion, he conveys surprise at the extent of the sea's transformative power and describes it as a force that 'demands an "answer". .. ${ }^{60}$ The poem elicits thoughts of both impermanence and renewal, as the sea 'shovels' the land around and stuns its inhabitants with its might. ${ }^{61}$

In these examples the sea is depicted as a site for revelation, rejuvenation and as an active force that resists and actively disrupts human plans. The proximity of the sea and coast to everyday life is portrayed as exposing the land's inhabitants to instability, power and awe in landscapes they can neither control nor avoid. The coast is represented as place where people can step beyond themselves to surrender to or experience the unknown. While these examples demonstrate the "inventiveness" inspired by New Zealand's coastal landscapes, they also convey the proximity and centrality of the sea and coast to island lives. As Charlotte Randall writes in Dead Sea Fruit, 'Less than an hour from the town, ... you could stand on these beaches and feel utterly alone, the wind stealing sound from your throat, or stirring up the sand against you. ${ }^{92}$

Beaches, coastal hills and an unrelenting sea are the landscapes that frame the areas where most Pakeha and other New Zealanders live and play. The 2006 national census shows that 65 percent of New Zealanders live within five kilometres of the coast and 75 percent live within ten kilometres. ${ }^{63}$ The same census shows that New Zealanders are becoming increasingly coastal. ${ }^{64}$ More recently, New Zealand Listener cited a survey conducted in October 2010, which finds that 64 percent of New Zealanders

\footnotetext{
59 Ibid.

${ }^{60}$ Ibid.

${ }^{61}$ Ibid.

62 Randall, Dead Sea Fruit, 12.

${ }^{63}$ Statistics New Zealand, "Are New Zealanders Living Closer to the Coast?," Internal Migration, Analytical Report, http://www.stats.govt.nz/browse_for_stats/population/migration/ internal-migration/are-nzs-living-closer-to-coast.aspx. ${ }^{64}$ Ibid.
} 
visited a beach in the previous twelve months. ${ }^{65}$ In comparison, 18 percent went camping or tramping. ${ }^{66}$ In The Miserables Damien Wilkins describes New Zealanders proximity to the coast and suggests it has cultural percussions. Healey recalls:

New Zealanders, he was saying, cannot ever be much more further than one hundred miles from the ocean. We have thirty-five times more coast to play with than Americans. The land is constantly interrupting our designs on it. In a sense, we have no interior. We are all edge. ${ }^{67}$

Bill Manhire also identifies the coast as a culturally significant landscape. In "Poem for Vanessa" in Zoetropes he describes New Zealanders as people who "live in dreams along the coast'. ${ }^{68}$ His next lines, 'They make their small dark noises / And they cry' suggests these dreams are not always happy. ${ }^{69}$ In "Milky Way Bar" in his collection of the same name, Manhire locates himself on the coast in writing, 'I live at the edge of the universe / like everybody else. .. .70 Here, New Zealand's edges are a site of connection rather than disconnection and the ordinariness of the lines conveys the familiarity and centrality of the sea and coast to New Zealand lives.

This centrality is further reflected in the inclusion of the sea and coast in representations of spirituality in domestic poetry, such as in the poems by Cilla McQueen and Lauris Edmond that I discussed earlier. Andrew Johnson provides another example in "Revisionism (I. The Present Tense)" in How to Talk in which he identifies the coast as a stage for the drama of life. He writes, 'The most important scenes are staged / on a particular stretch of coast. ${ }^{, 71}$ A fluidity and familiarity between

\footnotetext{
${ }^{65}$ Clifton, "Choice, Bro," 16.

${ }^{66}$ Sarah Barnett, "Welcome to Our World: What Recent Arrivals Think of New Zealanders," New Zealand Listener July 3-9, 2010, 20.

67 Wilkins, The Miserables, 233.

${ }^{68}$ Bill Manhire, "Poem for Vanessa," in Manhire, Zoetropes: Poems, 1972-82 (Wellington: Port Nicholson Press, 1984), 67.

${ }^{69}$ Ibid. 1991), 19.

70 _. "Milky Way Bar," in Manhire, Milky Way Bar (Wellington: Victoria University Press,

${ }^{71}$ Andrew Johnson, "Revisionism (I. The Present Tense)," in Johnson, How to Talk (Wellington: Victoria University Press, 1993), 9.
} 
person and place is suggested by his lines, 'While I am an audience the hill is backdrop; / we change places often, however. ${ }^{, 72}$ The domesticity of this beach scene conveys a sense of belonging, as Johnson describes a life played out in relation to place.

In Going West Maurice Gee also draws a coastal landscape into an expression of belonging and identity. Gee’s protagonist, Jack, and his wife, Harry, enjoy Wellington but never love it or feel the intensity of belonging they do in Auckland. For Jack, 'it never became, in forty years, my home. ${ }^{, 73}$ And, for Harry, 'these were not the right hills or this the right sea. ${ }^{, 74}$ Both are bound to Auckland and, more specifically, to the 'big cliffs and big sea' of Auckland's west coast. ${ }^{75}$ It is there that Jack feels a connection to 'knowledge' and 'a source' that provides enrichment. ${ }^{76}$ The feeling he gets from that particular landscape prompts him to immerse himself in it, as he claims, 'It's not just the view I need, I need to hear the waves' ${ }^{77}$

The examples I have given in this section are united in portraying the sea and coast as an active force that shapes the land and its inhabitants' lives. The predominance of the coast reflects its spiritual potency. It also resonates with New Zealand's geography, as writers place characters in familiar scenes and "work with materials that lie to hand"'. The depictions of spiritual experience and expression do not suggest nature romanticism, nature appreciation or a generalised love of a pan-New Zealand coastline. Rather, they give shape to spiritualities that articulate experiences of being at home and offer fragments of identities that are unfolding in relation to place. Thus, it is on 'a particular stretch of coast' that the drama of Johnson's life unfolds and, due to their connection to Auckland's west coast, Jack and Harry will be Aucklanders regardless of where they live. In the next section I demonstrate that representations of

\footnotetext{
72 Ibid.

${ }^{73}$ Gee, Going West, 90.

${ }^{74}$ Ibid., 199.

${ }^{75}$ Ibid., 90.

76 Ibid.

${ }^{77}$ Ibid., 15.
} 
spirituality in New Zealand's picturesque and iconic landscapes also express relationships between people and place.

\section{'It's not picturesque, / it's essential'}

Although they are removed from the experiences of most of the population, the country's picturesque or "pure” landscapes are highly visible. Pakeha see images all around them of New Zealand as an untarnished natural wonderland: in television commercials, as the subject of coffee table books or on billboards in airports, foreign countries and at the edges of provincial towns. One result of this exposure is a sense of proximity to these iconic but mostly distant scenes. ${ }^{78}$ It would, therefore, be unsurprising if Pakeha writers drew on stunning and picturesque locations as sites for spiritual expression.

Indeed, some writers draw the country's sublime landscapes into moments of introspection, fear or awe. For example, in "Visitors" in The Boy, the Bridge, the River Vincent O'Sullivan associates the Central Plateau with feelings of emptiness and unease. His suburban character prefers his own trees and sky to 'the desolation that brushed the mind when you thought of the expiring centre of the island. ${ }^{79}$ Lloyd Jones replaces desolation with a sense of awe in The Book of Fame in which he describes 'the thrill of knowing how at a glance the mountains can suck up all knowledge and render you speechless. ${ }^{80}$ And, in Let the River Stand O'Sullivan describes a mountain as a site of calm, as a character imagines 'an enchanted place' of stillness somewhere in the mountains. ${ }^{81}$

\footnotetext{
${ }^{78}$ James Brown, introduction to The Nature of Things: Poems from the New Zealand Landscape, ed. James Brown (Nelson: Craig Potton Publishing, 2005), 9; Claudia Bell, "The 'Real' New Zealand: Rural Mythologies Perpetuated and Commodified," The Social Science Journal 34, no. 2 (1997): 47.

${ }^{79}$ Vincent O'Sullivan, "Visitors," in O'Sullivan, The Boy, the Bridge, the River (Dunedin: J. McIndoe, 1978), 60.

${ }^{80}$ Lloyd Jones, The Book of Fame (Auckland: Penguin, 2000), 161-62.

${ }^{81}$ Vincent O'Sullivan, Let the River Stand (Auckland: Penguin, 1993), 178.
} 
Yet, other writers use spiritual vocabularies and representations of transcendence to draw iconic landscapes into articulations of belonging. Some writers elevate mountains from the picturesque to pervasive figures 'organising, dividing, illuminating our lives" ${ }^{82}$ To demonstrate, in "lessons from the Waitakeres" in Cold Snack Janet Charman expresses a personal connection to the Waitakere Ranges, which dominate the landscape. She depicts the ranges as deserving, demanding and receiving respect. She asserts:

don't interpret

their silence as insolence

these

are the mirrors

i will grow old in ${ }^{83}$

In these lines Charman casts the ranges as more than a back drop or foreboding scene. She suggests that there is reward gained by living in and knowing landscape, as the ranges have become a focus and constant in life. In "test test one two" in the same collection she conveys the familiarity of such landscapes to her life. She describes the sight of a mountain disrupting a routine drive to work, which infers that it too is an ordinary and extraordinary presence in everyday life. ${ }^{84}$

Some of Brian Turner's poems also suggest special knowledge and reward is gained by living in and opening oneself up to a particular place. Many of his poems are set in scenic Central Otago landscapes. His poetry can be outwardly spiritual, as he expresses gratitude and wonder for both the beauty of the landscape and the depth of connection he feels to it, but his landscapes are not sentimental or fantastical. They

\footnotetext{
${ }^{82}$ Frame, Living in the Maniototo, 134.

${ }^{83}$ Janet Charman, "lessons from the Waitakeres," in Charman, Cold Snack (Auckland: Auckland University Press, 2007), 15.

84 _ "test test one two," in Charman, Cold Snack, 4.
} 
represent the places he lives and knows, which are inhabited and bear human footprints. In "Van Morrison in Central Otago" in Beyond Turner dismisses nature romanticism, as he describes an experience of the sea and mountain air as a physical and emotional experience. He states, 'It's not picturesque, / it's essential, almost / grand, . . .85 Turner also rejects romanticism in "Always the Hills" in Ladders of Rain in which he commands the reader to:

Witness all this obdurate might, dismiss all talk of 'rare beauty' or 'lyric fastness' as piffle of those whose words spill profuse and scatty as leaflets flickering light There are

always the hills regal or motley, stared at and staring, their thriving in us, our thriving in them. ${ }^{86}$

In these poems Turner acknowledges the romantic tradition but discounts posturing over beauty and grandeur to assert the necessity of reciprocal relationships with landscape. Turner's hills in "Always the Hills" are more than a pretty scene; they puncture, frame and shape life. People face them and become who they are in partnership with them, and they are better for the interaction. For Turner, this interaction can grant the landscape's inhabitants with knowledge, enrichment and orientation. But the converse also applies, as these rewards are denied to outsiders. ${ }^{87}$

Kendrick Smithyman similarly articulates the necessity of personal knowledge of place. In "Movements for Coastal Voices (3)" in Stories About Wooden Keyboards he asserts, 'Political analysts should travel to touch / barks of these pohutukawas and tall

${ }^{85}$ Brian Turner, "Van Morrison in Central Otago," in Beyond, 10.

86 _. "Always the Hills," in Turner, Ladders of Rain, 37.

87 See _ _Madness and the Mountain," in Turner, Ladders of Rain, 34-37; "Yokels," in Turner, Beyond, 56-57. In "Madness and the Mountain" Turner infers that knowledge of place is denied to outsiders when he contrasts a learned understanding of place with 'the tourist's instamatic view'. In "Yokels" he contrasts local knowledge with the posturing of 'the little people / of Auckland'. 
manuka,' suggesting that those who live within their shadow can better protect and nurture them. ${ }^{88}$ In "Reading the Maps, An Academic Exercise" Smithyman speaks to the limits of a superficial knowledge of place, as he casts maps as an act of fiction. He writes:

\section{Maps can}

tell you about what is supposedly present.

They know little about what's past and only so much about outcomes. ${ }^{89}$

Smithyman, Turner and Charman's assertions of knowledge gained by living in and opening oneself up to a particular landscape give voice to themes of belonging and home. While the landscapes are iconic, the poets' sentiments reject nature appreciation or a generic love of the land. Rather, they assert and express feelings of belonging as they describe identities defined by place. Turner and Smithyman suggest division but convey the depth of reward that may be gained from identifying with landscape. They suggest belonging and knowing place is a source of shared but exclusive experience.

The local focus that I have detected and demonstrated over the past two sections gives shape to a rich spiritual current that articulates experiences of being at home. The location of spiritual expression in the landscapes many Pakeha live in or near is suggestive of changes in literary themes. In the next section I discuss developments in bush mythologies in Pakeha literature that have resonance with changes in the ways many Pakeha are living in and relating to landscape.

\footnotetext{
${ }^{88}$ Kendrick Smithyman, "Movements for Coastal Voices, (3)," in Smithyman, Stories About Wooden Keyboards (Auckland: Auckland University Press, 1985), 35.

89 _, "Reading the Maps, An Academic Exercise," in Smithyman, Stories About Wooden Keyboards, 41.
} 


\section{"Home is where the bach is. We're past all that."}

In Portrait of the Artist's Wife Barbara Anderson's characters argue about the relevance of "man alone" mythology to contemporary Pakeha culture. Charles claims, "The little grey hut in the bush built by man alone. Home is where the bach is. We're past all that," while Sarah argues that the passing of "the bush and bach" experience means Pakeha need such myths now more than ever. ${ }^{90}$ The paucity of bush imagery within my sources seems to support Charles' assessment. Yet, there is evidence of enduring but dynamic bush mythologies. In this section I provide examples of the romanticised and foreboding bush of New Zealand's literary past re-imagined and brought closer to home. This change in location reflects literary trends and further suggests that many Pakeha locate their sense of themselves within their urbanity. Their identities are unfolding by being at home. I begin by discussing bush mythologies in Pakeha literary history.

In his overviews of New Zealand's literary histories, Lawrence Jones discusses the development of landscape themes through four periods of New Zealand literature. The themes are connected to the myths of New Zealand as a 'Pastoral Paradise', 'Just City' and the emergence of the 'Affluent Suburbs'. ${ }^{91}$ Thus, they focus on the social and cultural reverberations of New Zealand's colonial transformation, in which Pakeha settlers remade the indigenous landscape into pastoral land, provincial towns and, eventually, cities and suburbs. Jones' overviews identify the bush as a culturally significant landscape that Pakeha writers have imagined and re-imagined from the Early Colonial to the current, Post-provincial, literary period.

Jones begins his histories with the Early and Late Colonial periods, in which 15.

${ }^{90}$ Barbara Anderson, Portrait of the Artist's Wife (Wellington: Victoria University Press, 1992), $14-$

${ }^{91}$ Jones, "Versions of the Dream," 187-91, 195-202;____ _"The Novel," 129-30, 139, 141, 157-159; - Picking up the Traces, 12-13, 173-75. 
Pakeha writers offer glimpses of both optimism and regret for a process of rapid ecological change. ${ }^{92}$ He generalises Early Colonial writers as using landscape as a picturesque backdrop for the drama and heroics of the mental and physical tribulations of clearing the land. ${ }^{93}$ By the Late Colonial period, some writers claim to see only rudiments of their society lying in the ashes of a 'mutilated bush. ${ }^{94}$ Those writers muse on the costs of progress or express regret for carving rough paddocks out of the land. ${ }^{95}$ Despite the state of the landscape, an overriding faith in the country's progress prevails. ${ }^{96}$

As I discussed in Chapter One, between the Late Colonial and Provincial periods, New Zealand's inchoate literary establishment underwent a sea change in its aims and stance towards popular nationalism and social norms. ${ }^{97}$ Where earlier writers offered a predominantly positive view of New Zealand society, early Provincial writers sought to challenge a society they saw as monocultural, puritanical and dull. ${ }^{98}$ Landscape themes were central to their critiques, as writers located their society in a landscape that been irreparably and arrogantly damaged in a failed attempt to create the Pastoral Paradise. $^{99}$

Some Provincial writers diagnosed spiritual emptiness, borne from alienation from the landscape, as a central component of the "national" character. ${ }^{100}$ They identified nature, or landscape, as a source of redemption from the country's social and cultural ills. ${ }^{101}$ Charles Brasch's often-cited poem, "The Silent Land", encapsulates this

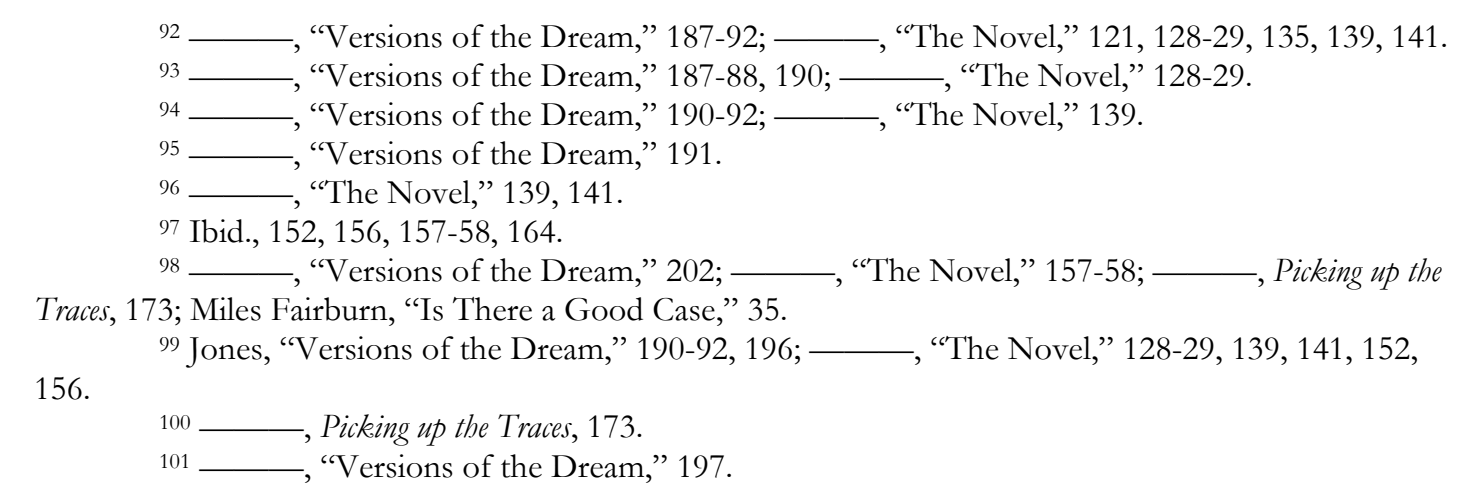


turn to the landscape. He writes, 'Man must lie with the gaunt hills like a lover, / Earning their intimacy in the calm sigh'. ${ }^{102}$ During this period the bush was portrayed romantically, as a refuge from its antithesis: the repressive and spiritually arid provincial town. ${ }^{103}$ Monte Holcroft influentially identified the bush as a source of reprieve, as he wondered if it might yet provide an alienated settler society with 'a source of power in an adventure of the spirit. ${ }^{, 104}$

In this brief overview the bush has been constructed and reconstructed as a picturesque backdrop, the bedrock for an inchoate nationalism and the root of collective unease. The sparse bush imagery within my selection of Pakeha literary fiction suggests further development. Apart from Maurice Shadbolt's The Lovelock Version and Season of the Jew, characters do not "go bush" to find themselves, to escape society or each other. ${ }^{105}$ However, there are re-imagined bush mythologies located in landscapes that are closer to home.

To illustrate, in Maurice Gee’s “Eleventh Holiday” in A Glorious Morning, Comrade a father flees to the bush surrounding his regular camping ground to escape an argument and his awareness of his loss of power to the younger generation. ${ }^{106}$ After he punches a young man from a nearby camp, he seeks the bush to 'hide in the darkest place he could find'. ${ }^{107}$ In "The Widow” in the same collection Gee depicts a rural landscape as a site of refuge from life in the city. A young office worker experiences a moment of transcendence while swimming in an inlet at his relations' dilapidated farm. He feels that 'everything that had happened yesterday was washed away. He had no memory of anything as it should not be. This was what he had come for - to swim, and

102 Charles Brasch, "The Silent Land," in The Penguin Book of New Zealand Verse ed. Allen Curnow (Harmondsworth: Penguin Books, 1960), 183-84.

${ }^{103}$ Jones, Picking up the Traces, 73; —_ " "The Novel," 157-58.

105 Maurice Shadbolt, The Lovelock Version (London: Hodder and Stoughton, 1980);

104 Monte Holcroft, "The Deepening Stream," in Discovered Isles, 31; Roberts, "Can Identity Be Season of the Jew (London: Hodder and Stoughton, 1986).

106 Maurice Gee, "Eleventh Holiday,” in Gee, A Glorious Morning, Comrade, 119.

107 Ibid., 122. 
be by himself, and wander wherever his feet took him'. ${ }^{108}$ John Cranna creates a similar scene in "Soft Targets" in Visitors in which the view from rural hills causes a young university student's stress to dissipate in an instant. As he sits alone in the hills 'layers of obscure detail that had crusted in my mind began to dissolve in the burning sun, and before the scale of the plain and the blue emptiness of the sky, my coming exam results seemed a puny irrelevance. ${ }^{109}$

In other examples, remnants of a foreboding bush are located on the city fringes and even in back gardens. For instance, in The Blue Mary McCallum's character senses something sinister in pine trees that line the back of her house. Here, the proximity of the bush is an inescapable reminder of her isolation. ${ }^{110}$ In Charlotte Randall's Dead Sea Fruit the sense of threat is also close to home, as two characters feel the inviolable silence' of the bush as they walk out of town. ${ }^{111}$ In Gee's "Right-hand Man" in $A$ Glorious Morning, Comrade a city councilor struggles against the town's green belt in a fight for relevance. He "goes bush" by fleeing to and trying to control pine trees that represent 'something dark and untamed that must be brought under control'. ${ }^{12}$ And, in Oracles and Miracles Stevan Eldred-Grigg depicts a rural landscape as a site of alienation and insecurity. Outside Christchurch, Fagg finds that the rural landscape 'gave me the creeps' as it is 'all just too lonely and big. ${ }^{113}$ Her sister, Ginnie, shares this sentiment, describing 'the country' as 'very lonely, very big and lonely to me, very empty. ${ }^{114}$

These examples indicate that the landscape themes of New Zealand's literary past have senescence, as Post-provincial writers reflect and refract their literary heritage

\footnotetext{
108 _ "The Widow," in Gee, A Glorious Morning, Comrade, 60.

109 John Cranna, "Visitors," in Cranna, Visitors, 73.

110 Mary McCallum, The Blue (Rosedale, N.Z.: Penguin, 2007), 61-62.

111 Randall, Dead Sea Fruit, 44.

112 Maurice Gee, "Right-Hand Man," in Gee, A Glorious Morning, Comrade, 184.

113 Stevan Eldred-Grigg, Oracles \& Miracles (Auckland: Penguin, 1987), 207-08.

114 Ibid., 239.
} 
and the work of their peers. ${ }^{115}$ The re-imagining of bush mythologies in local landscapes indicates that many Pakeha writers have liberated themselves from the Provincial period constructions of a dichotomy between the bush and the repressive provincial town.

This development resonates with changes in literary trends, the landscape, and the ways Pakeha are living in and relating to it. ${ }^{116}$

A dichotomy between the bush and town has less relevance in a mostly urban and suburban society. The earlier constructions of a foreboding bush are also dissonant. While contemporary writers convey different levels of ease in the landscape, they and their Pakeha readers mostly have nowhere else that is home and thus, are not contrasting a scrappy bush with idealised images of rolling hills in the English countryside or the moody mires of Scotland. Nor are they lamenting over the charred remains of recently cleared bush and thus, they are unlikely to produce a poem like Blanche Baughan's “A Bush Section”. ${ }^{117}$

The local focus that I have discussed over the past three sections articulates experiences and assertions of belonging rather than alienation. This change demonstrates the dynamic and developing nature of Pakeha literature, as writers muse on contemporary experiences and "work with materials that lie to hand". The location of spiritualities in local scenes conveys the enrichment and orientation gained by feeling at home.

However, there are indications that the bush endures as a significant landscape to explore and articulate Pakeha settler origins and, as settler-descendents, the unfolding of Pakeha cultural identity. As well as Maurice Shadbolt's novels, the romanticised or foreboding bush of New Zealand's ecological and literary past is represented in other historical novels, such as Annamarie Jagose's Slow Water and Fiona Kidman's The Captive

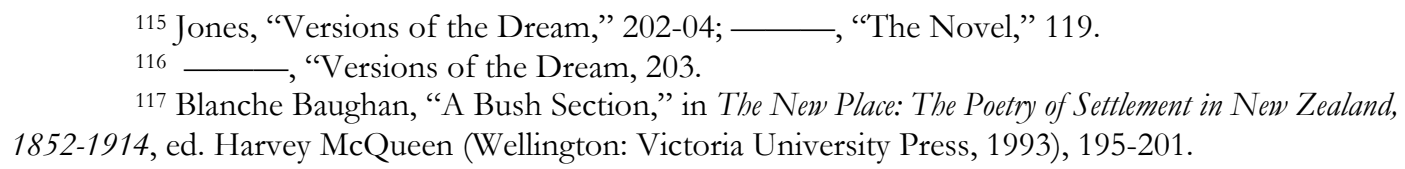


Wife. ${ }^{118}$ Kendrick Smithyman's allusion to madness in the bush in 'Legend of Sara's Gully" in Stories About Wooden Keyboards is also set in the colonial period. ${ }^{119}$ I provide further examples in the next chapter. These fragments of bush mythology suggest that the bush remains an important vehicle for exploring the Pakeha settler story.

The spiritual landscapes that I have located and articulated in this chapter are mostly local, whether they are along the coast or within sight of familiar mountain or plain. These landscapes are inhabited, transformed and a part of the every day or weekend experiences of many Pakeha. The representations of reverence, revelation, transformation and transcendence within these landscapes portray relationships between person and place that shape and are shaped by a person's self-understanding. They are described in the vocabularies of belonging and home. The poems by Cilla McQueen that convey a life lived in concert with landscape, Brian Turner's assertions of the necessity of knowing place and Bill Manhire's identification with the country's edges convey the importance of landscape to identity. Collectively, the spiritualities that I have identified and discussed suggest that many Pakeha locate and express their identities in a sense of belonging in landscape or by being "at home". In the first part of the next chapter I demonstrate how my writers draw landscape into shared experience and collective life.

118 Annamarie Jagose, Slow Water (Wellington: Victoria University Press, 2003), 137; Fiona Kidman, The Captive Wife (Auckland: Vintage, 2005), 155.

${ }^{119}$ Kendrick Smithyman, "Legend of Sara's Gully," in Smithyman, Stories About Wooden Keyboards, 33. 


\section{CHAPTER FOUR}

\section{THE PROBLEMS OF PAKEHA BELONGING}

In his essays on the histories of landscape and people in New Zealand, Geoff Park states that landscape 'show[s] us who we are, and who, culturally, we have been'. For Pakeha, part of this story is a history of migration, colonisation and comprehensive ecological transformation. This chapter is in two parts. In the first part I demonstrate how landscape is portrayed as a focus and source of collective experience.

Representations of landscape as a site for establishing and maintaining interpersonal and "imagined" relationships identify it as a ground for personal, collective and spiritual lives. Building upon the last chapter, the examples I give indicate that landscape is a significant vehicle for exploring and expressing Pakeha identities. I shift focus in the second part of the chapter, as I discuss a theme of desecration as an illustrative example of the challenges to Pakeha belonging. Although I focus on ecological tensions, I locate this theme within the web of contestations that reverberate from New Zealand colonial history and Pakeha settler origins. I end the chapter with themes of belonging and desecration, which I draw together in Chapter Five.

\section{Part One: Looking to the Landscape}

In this part of the chapter I discuss how landscape is portrayed as a source and focus for collective experience within my sources. The examples I provide depict landscape as a site for maintaining interpersonal relationships and participating in community. Building upon the last chapter, they suggest many Pakeha locate and articulate their personal, collective and spiritual identities in relationships with landscape. I begin with representations of landscape as a source of communion and

${ }^{1}$ Geoff Park, "A Moment for Landscape," in Theatre Country: Essays on Landscape and Whenua (Wellington: Victoria University Press, 2006), 197. 
focus for celebration of family and friends over time, distance and dimension. I then demonstrate how landscape is depicted as a point of identification with community and a vehicle for exploring Pakeha settler histories.

\section{'Wherever I smell salt and feel sand blow against my skin, I have come home.'}

In 1905 Late Colonial novelist Edith Searle Grossmann wrote, 'The bush is no longer an empty and lifeless waste; it is haunted by the memories of our childhood.' Although Grossmann gives voice to a landscape ethic that haunts many Pakeha, she expresses an emerging sense of identification with place. As she looks to the bush and sees herself reflected she identifies with it and, slowly, she starts to belong. In doing so, she becomes less like the generation of settlers before her and more like others who feel the same. Many of my writers locate memories and personal histories of their characters and themselves in landscape. In memorialising interpersonal relationships in local scenes they convey a sense of belonging that is strengthened by being at home.

In his novel, $\mathrm{Meg}$, Maurice Gee portrays a powerful sense of belonging focussed on a particular place. He depicts Meg's attachment to her beloved home, Thorpe, and Christchurch as a kind of spiritual nourishment. In adulthood Meg recalls her despondency when she and her family left Thorpe to live in California. Ostensibly, the opportunities offered by her new home outweighed Thorpe's grey ditches, black pines and cold willows but Meg found herself stunted, as she 'longed for Thorpe with a longing like that for food. ${ }^{3}$ Although she rejects religion, claiming, 'I would have none of God, and none in this existence of an after-life. I was committed to a life of feeling, the life of now', Meg recalls her realisation that she was incomplete without 'something

\footnotetext{
${ }^{2}$ Edith Searle Grossmann, "The Growth of a Colonial Settlement" cited in Keith Sinclair, $A$ Destiny Apart: New Zealand's Search for National Identity. (Auckland, Allen \& Unwin, 1986), 6.

${ }^{3}$ Maurice Gee, Meg (London: Faber, 1981), 34-35.
} 
in the air and in the ground' around Christchurch. ${ }^{4}$ Without the 'deep and instant recognitions, of things seen and touched and heard' at home, Meg found that a part of herself was gone. ${ }^{5}$ She did not belong in California; she was no longer at home.

While Meg's attachment to place is realised via distance, in "Wellington Letter (III)" in Selected Poems Lauris Edmond depicts a bond between place, person and memory that is strengthened while at home. In this poem Edmond constructs landscape as a physical reminder of the love and loss she feels for her child. She writes:

I planted a totara for you, its tough sprigs to contain your delicacy, your grace, Rachel. ${ }^{6}$

By planting a tree to embody the spirit of her daughter, Edmond inscribes her personal history in her garden. She creates a bond between her daughter, the landscape and herself that binds her to her home.

In $A$ Rocky Shore Jenny Bornholdt also locates memories of her family in a domestic garden. In "A Rocky Shore” and "Big Minty Nose" she recalls her grandmother via a plum tree and her father while planting flax. ${ }^{7}$ Unlike Edmond, Bornholdt expresses an occasional desire to disassociate memory from place. In "A Rocky Shore" she states, 'Sometimes I would like the garden to be just / the garden and not a place of memory. ...' and wonders, 'Why this need / to name and place everything? ... ${ }^{8}$ The landscapes depicted by Edmond and Bornholdt are more than property. As a site for memory, they are the ground in which relationships that shape identities are inscribed and maintained.

${ }^{4}$ Ibid., 39.

${ }^{5}$ Ibid.

${ }^{6}$ Lauris Edmond, "Wellington Letter (III)," in Edmond, Selected Poems, 45.

7 Jenny Bornholdt, "The Rocky Shore," in Bornholdt, The Rocky Shore (Wellington: Victoria University Press, 2008), 22; __ , "Big Minty Nose," in Bornholdt, The Rocky Shore, 65.

8 Bornholdt, “'The Rocky Shore," 22. 
This investment of memory and personal history in landscape is not confined to domestic gardens. Other writers infuse local landscapes with memories of the relationships that shape lives. For instance, in "On the Death of my Grandmother" in Playing God Glenn Colquhoun depicts the sea and coast as a site for memory, as he uses coastal imagery to articulate an acceptance of death. He describes wave after wave coming to shore to wash away a sand sculpture shaped like a man. Each wave represents the brevity and continuation of life. Thus, 'The tenth wave would have never known / that he had been there in the first place." Yet, in portraying the passage of life and death as a scene played out on the coast, Colquhoun asserts that people live on in memory.

These representations of landscape as a site for personal history demonstrate one of the ways landscape is drawn in to collective experience. As people bury their dead in landscape, it becomes a source of connection to those passed. Thus, for Colquhoun, a familiar coast becomes a focus for celebrating the enduring essence of those loved and lost. As conveyed by Edmond and Bornholdt, this inscription of personal and collective history in landscape further binds person to place.

Beyond interpersonal relationships, my writers also represent landscape as a focus for participating in the "imagined community" of the nation. Benedict Anderson describes the nation as imagined, as it is a form of 'community in anonymity' where individuals feel a sense of togetherness with people they will mostly never meet, hear or know. ${ }^{10}$ Thomas Luckmann identifies participation in the nation as a form of intermediate transcendence, which brings collective experience into the spiritual realm. ${ }^{11}$ Representations of landscape as a vehicle for participating in the imagined religious

\footnotetext{
9 Glenn Colquhoun, "On the Death of My Grandmother," in Colquhoun, Playing God (Wellington: Steele Roberts, 2002), 25.

${ }^{10}$ Benedict Anderson, Imagined Communities: Reflections on the Origin and Spread of Nationalism, Revised and extended ed. (London: Verso, 1991), 5-6, 36.

${ }^{11}$ Luckmann, "Shrinking Transcendence, Expanding Religion?," 128-30, 135.
} 
communities' of the nation are most apparent in poetry and prose by writers who are abroad or depict characters who are abroad. ${ }^{12}$

To demonstrate, in "Bird on the Wire" in Pieces of Music Michael Jackson constructs landscape as a point of identification between two New Zealanders abroad. One character's enduring connection to his life in New Zealand is located in his attachment to 'the wild coasts of New Zealand and the sea'. ${ }^{13}$ A fellow New Zealander expresses recognition in stating, 'I told him that in my many years abroad I had never ceased to pine for the ironsand beaches of the west coast. It was for the unpolluted air, the green hills and the sea that Pauline and I would one day return home. ${ }^{14}$ In this example Jackson identifies shared experiences of landscape as a point of communion between two characters whose lives have diverged.

A relationship between landscape and national identity is further indicated in representations of landscape as a symbol for the feelings associated with belonging and being at home. In these examples memories of landscape connect Pakeha to their New Zealand and Pakeha identities over other aspects of their collective lives. Again, the coast is a significant spiritual landscape, which is portrayed as orienting Pakeha towards each other, themselves and home. For instance, in The Word Burners Beryl Fletcher associates coastal landscapes with homecoming, as her character feels 'the pull of the land' while she is away. ${ }^{15}$ She exclaims, 'I don't give a damn if it's the wild west coast or a walled place of watered lawns and picnic tables. Wherever I smell salt and feel sand blow against my skin, I have come home. ${ }^{, 16}$

Kevin Ireland provides another example in "A Literary Exile" in Literary Cartoons. He describes memories of trying to write poetry on an Auckland beach as

12 Casanova, "Rethinking Secularization," 19.

${ }^{13}$ Michael Jackson, "Bird on the Wire," in Jackson, Pieces of Music (Auckland: Vintage New Zealand, 1994), 166.

14 Ibid.

${ }^{15}$ Fletcher, The Word Burners, 103.

16 Ibid., 36. 
'images he keeps for good luck in his exile. ${ }^{17}$ Significantly, "A Literary Exile" is the only poem in the collection that concerns personal history and it is a moment in landscape that the literary man holds on to 'as he grows older and closer to his past'. ${ }^{18}$ His memories of landscape help him to maintain his identity as a New Zealander.

In other examples my writers draw New Zealand landscapes into foreign scenes in attempts to feel the comfort of home. For example, in "Writing Home (5)" in It Has No Sound and Is Blue Dinah Hawken expresses a sense of loneliness and distance from her life in New Zealand while she is in New York. She remembers home in terms of landscape, as 'that slow green complacent place called home'. ${ }^{19}$ In "Winter. New York," in the same collection she describes whittling a piece of native wood to maintain a connection with her New Zealand life. ${ }^{20}$ She also imagines New Zealand landscapes in New York city scenes. ${ }^{21}$

Cilla McQueen also finds comfort in imagining familiar landscapes in moments of transcendence while away from home. In Berlin Diary she writes that her Aramoana landscape is 'Vivid even from / this viewpoint in crowded Germany'. ${ }^{22}$ Visions of home emerge from memory in urban locations, such as in voices in a crowded café that produce the 'closest sounds I've found to the sea, / to trees and water'. ${ }^{23}$ She describes 'tracing in my mind the view / from the rock above Carey's Bay' while leaning out a window that overlooks a city street. These fragments of landscape and memory orient McQueen towards her identity and home.

In these examples the writers are united in portraying landscape as a focus for collective experience and identity. They use landscape to embody what it means to be a

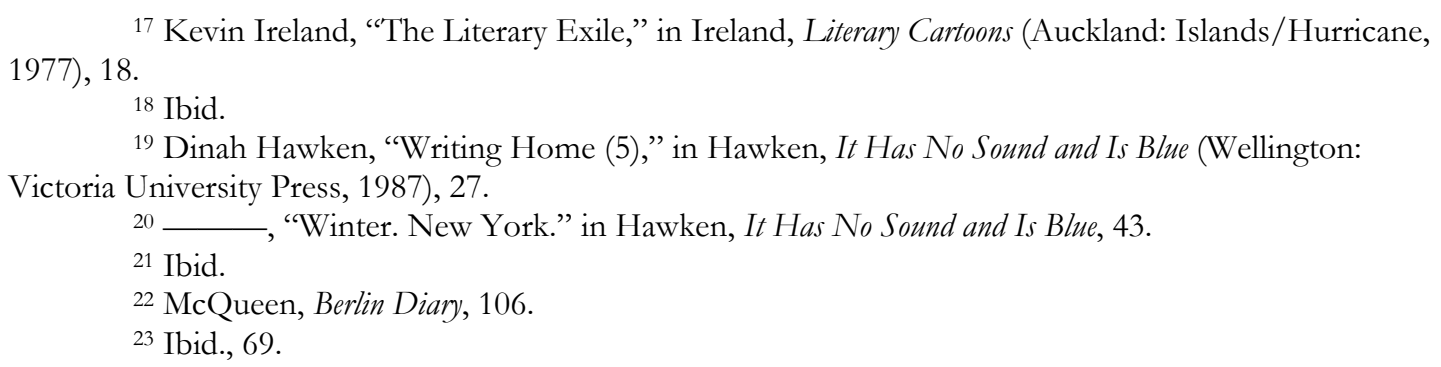
1977), 18.

${ }^{17}$ Kevin Ireland, “The Literary Exile," in Ireland, Literary Cartoons (Auckland: Islands/Hurricane,

${ }^{18}$ Ibid.

${ }^{19}$ Dinah Hawken, "Writing Home (5)," in Hawken, It Has No Sound and Is Blue (Wellington: Victoria University Press, 1987), 27.

20 _- "Winter. New York." in Hawken, It Has No Sound and Is Blue, 43.

21 Ibid.

22 McQueen, Berlin Diary, 106.

${ }^{23}$ Ibid., 69. 
New Zealander and how it feels to be at home. Thus, for Fletcher and Ireland landscape pulls Pakeha back to New Zealand. For Hawken and McQueen a blending of landscape and identity helps them to orient themselves in places they do not belong. Jackson's choice of landscape to create common ground between two people whose lives have diverged demonstrates the pervasive influence of landscape on identity. These examples suggest that many Pakeha look to landscape to express how they relate to others both near and far. There are also indications that landscape is a focus for understanding the people and places from whence Pakeha came. In the last chapter I identified the bush as an enduring link to Pakeha settler stories. In the following examples I demonstrate how landscape is represented as a vehicle to explore the past and the unfolding of Pakeha identities in the present.

For some, an enduring landscape provides insight into an unknown past. For instance, in The Singing Whakapapa C.K. Stead's protagonist, Hugh, embarks on a journey of personal discovery. At the end of the novel, as Hugh looks over a personally significant landscape, family history comes to him via memories that emerge 'at first like a word on the tip of the tongue, an atmosphere, a dream recovered with difficulty, reforming into fragments which, with patience and concentration and passivity, would form a picture. ${ }^{24}$ These fragments coalesce into a certainty that Hugh and the generations that came before him are bound to this site. Hugh finds that he carries a version of the Auckland isthmus in his head, as his history and identity are bound together 'place-to-place, person-to-person, person-to-place'. ${ }^{25}$ It is through experiencing the same landscape as his ancestors that Hugh understands who he is, and from whom and whence he came.

In "Pioneers" in W all Michael Jackson expresses a connection with his Pakeha

${ }^{24}$ C.K. Stead, The Singing Whakapapa (Auckland: Penguin, 1994), 274.

25 Ibid., 253. 
ancestors through shared experiences of landscape. He locates his sense of identity in his ancestral heritage in stating, ' $\mathrm{I}$ am theirs and of them and for them speak. ${ }^{26} \mathrm{He}$ describes shared experiences of rain and trees, seeing his ancestors' faces and imagining their toil 'in the bush they cleared. ${ }^{27}$ Significantly, he states that he has lived in the landscapes they transformed and (re)named. ${ }^{28}$ He writes:

I am theirs and of them and for them speak. My hands have gone over the roofs and gullies of their names.

These hills I live under are their doing. I have been given what they got. I am what they became. ${ }^{29}$

Here, Jackson identifies landscape as path to an unknown past. It ties him to his heritage as his heritage ties him to the landscape. As well as conveying personal history, Jackson alludes to transformative relationships between landscape, personal and collective identities. His ancestors were changed by their experiences of transforming the landscape. The landscape became something different under their hands. And, Jackson is 'of them' but distinct from them as his identity is shaped by his experiences of the landscapes they transformed. His line, 'I have been given what they got,' prompts thoughts of how his ancestors' obtained land. Although he has chosen 'got' over a more damning choice, such as "took", the line infers prior ownership. This poem identifies landscape as a link to personal history and alludes to its formative influence in constructions of Pakeha cultural identity. Some of the questions it raises about New Zealand's colonial history inspire less comfort than Jackson suggests, as I discuss later in this chapter.

As my writers draw on landscape to imagine and represent the lives of their

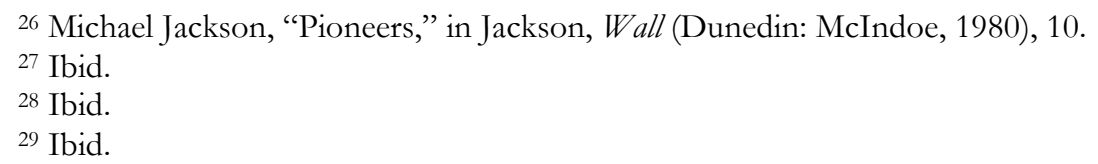


ancestors, they convey both recognition and distance from the settler experiences that shape contemporary Pakeha identities. Suggestions of dissonance between current and past experiences demonstrate the dynamism of constructions of cultural identities and landscape. To illustrate, in "Songs for a Far Island” in Homing In Cilla McQueen illuminates the transformative influence landscape can have on identity. She expresses her sense of connection to her Scottish heritage, writing:

I am my name: see myself threading back through the generations, tough as a cord ${ }^{30}$

Yet, McQueen articulates a rupture, as her experiences of living in New Zealand have shaped her identity and made her distinct from her ancestors. She describes her ancestral home, a remote Scottish island, as harsh and bleak. ${ }^{31}$ She writes:

Such was the barrenness

of their birthplace, my ancestors did not know trees. ${ }^{32}$

She contrasts her ancestors' experiences with her own, writing:

- yet here \& now

I live among trees:

keeling willows,

stippled ngaio leaves, kowhai, rangiora,

$\&$ wind in them all ${ }^{33}$

It is notable that McQueen mostly lists endemic trees, signalling a distance between her ancestral roots and her life in New Zealand. McQueen indicates that her

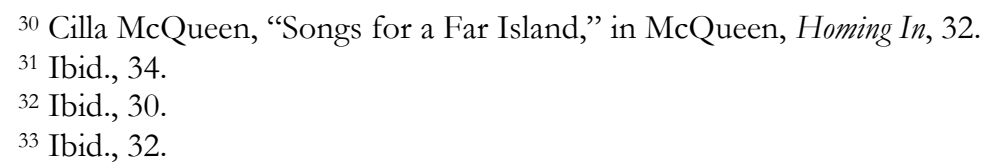


experiences of New Zealand landscapes have shaped the person she has become, as she states, 'Not to know trees / would be not / to know the wind.' 34 While she imagines her ancestors 'DRIVEN \& LONGING / FOR THE GREY WIND' and acknowledges that she is bound to their experiences, her identity is rooted in local soil. ${ }^{35}$ Landscape connects McQueen to her settler origins and has helped to define the person she has become.

These representations of landscape as a focus for personal and collective histories, a source of togetherness and community, and a way to celebrate family and friends portray landscape as a significant site for collective experience. It is a location to explore and maintain the meaningful relationships, interpersonal and imagined, that give shape to life. Alongside the articulations of belonging that I discussed in the last chapter, the examples I have given in this section indicate that landscape is a significant vehicle for many Pakeha to explore and express their unfolding personal, cultural and spiritual identities. It is a focus for their ideas of who they think they are, how they relate to others and who they may become. It is a ground for personal, collective and spiritual life.

However, the relationships between landscape, spirituality and Pakeha cultural identity are not easy. Pakeha attempts and assertions of belonging are subject to challenges that reverberate from New Zealand's colonial history and Pakeha settler origins. In the next part of this chapter I shift focus to discuss a theme of desecration that suggests many Pakeha are aware of the problems of their belonging. I begin by locating the challenges to Pakeha belonging, and relationships between landscape, spirituality and identity, within the identity concerns of white settler states.

\footnotetext{
34 Ibid., 30.

35 Ibid., 32.
} 


\section{Part Two: The Landscape Looks Back}

\section{'We're only now beginning to look closely at the place we're living in.'}

As a former British colony, New Zealand is grouped with other white settler states that were formed during a period of mass emigration from Europe in the early nineteenth to early twentieth centuries. ${ }^{36}$ These states are united by the disparity between their white settler cultures' European cultural heritage and their location. ${ }^{37}$ The shared histories of migration and colonisation create particular complexities for white settler cultures, as their identities are suspended between "mother" and "other", and they lack the security of unproblematically belonging "at home". ${ }^{38}$

This 'ontological unease' was keenly felt by Pakeha from the mid-1970s, and increasingly in the 1980s, when Britain entered the European Economic Community and the Maori Renaissance forced Pakeha to question their cultural legitimacy and their sense of belonging in New Zealand. ${ }^{39}$ The key myths of a 'hegemonic settler nationalism', such as egalitarianism and New Zealand as 'Better Britain', which had legitimatised colonial processes were challenged and caused considerable unease. ${ }^{40}$ After this upheaval, some Pakeha sought to construct postcolonial identities in relation to a colonial history and bicultural future with Maori in a contested and damaged

\footnotetext{
${ }^{36}$ Bell, "Dilemmas of Settler Belonging," 145; Alfred Crosby, Ecological Imperialism: The Biological Expansion of Europe, 900-1900 (Cambridge; New York: Cambridge University Press, 2004), 5; Dunlap, Nature and the English Diaspora, 1.

${ }^{37}$ Crosby, Ecological Imperialism, 2-3; Dunlap, Nature and the English Diaspora, 5.

38 Bell, "Bifurcation," 254-56;____ "Dilemmas of Settler Belonging," 145, 147-48; Alan Lawson, "Postcolonial Theory and the 'Settler' Subject," Essays on Canadian Writing 56 (1995): 25.

${ }^{39}$ Belich, Paradise Reforged, 425, 431-35, 465, 477-78, 487, 515; Simon During, "Postcolonialism and Globalisation: A Dialectical Relation after All?," Postcolonial Studies 1, no. 1 (1998): 34-36; Paul Spoonley et al., introduction, 9, 12; Pearson, "Concept or Conundrum," 68-69; Bell, "Bifurcation," 25456; __ , "Dilemmas of Settler Belonging," 145, 147-48; Bell, Inventing New Zealand, 26-27; PoataSmith, "He Pokeke Uenuku I Tu Ai," 97, 105.

${ }^{40}$ Mark Falcous, “The Decolonizing National Imaginary: Promotional Media Constructions During the 2005 Lions Tour of Aotearoa New Zealand," Journal of Sport and Social Issues 31, no. 4 (2007): 378-79; During, "Postcolonialism and Globalisation," 34-36; Bell, "Bifurcation," 256; Fleras and Spoonley, Recalling Aotearoa, 87.
} 
landscape. $^{41}$

Avril Bell compares the resulting crisis of Pakeha cultural identity to Meaghan Morris' idea of 'human hinges', identifying Pakeha as a culture caught between their past and present and destabilised by their concurrent statuses as migrants, colonisers and colonials. ${ }^{42}$ Stephen Turner claims that as 'colonial beings' Pakeha are burdened by 'hints that the place isn't or wasn't yours, isn't for you, isn't even about you.'43 And, he asserts that Pakeha will always be troubled by not knowing 'about the bit before you came'. ${ }^{44}$ These multiple identities and challenges of biculturalism concern a key strand of discourse on the role of landscape in reconstructions of Pakeha cultural identity. Pakeha attempts to reconstruct a sense of belonging via relationships with landscape, or "make the land about them", have received voracious criticisms. Popular assertions of belonging, such as those by Michael King, have been cited as an example of Terry Goldie's thesis of 'indigenization' and criticised for undermining the status of Maori as tangata whenua. 45 These challenges by Pakeha about Pakeha claims of belonging demonstrate that Pakeha are denied and deny themselves straightforward constructions of spirituality and identity in landscape.

Some of my writers address the complexities of biculturalism and the challenges it brings to Pakeha attempts and assertions of belonging. For example, in The Carpathians Janet Frame depicts Pakeha as a culture that is plagued by the brevity of its occupation. Thus, multiple Pakeha characters describe themselves as strangers in the

\footnotetext{
${ }^{41}$ Bell, "We're Just New Zealanders," 146; Fleras and Spoonley, Recalling Aotearoa, 86-87; King, Being Pakeha Now, 234-35. In this thesis my use of 'postcolonial' refers to a 'continual engagement with the lasting effects of colonialism' rather than 'after colonialism'. See Eric Pawson, "Postcolonial New Zealand?," in Cultural Geographies, eds. Kay Anderson and Fay Gale (Melbourne: Longman, 1999), 30.

42 Bell, "Dilemmas of Settler Belonging," 147; _—_ "Bifurcation," 253-56; Meaghan Morris, "Afterthoughts on 'Australianism'," Cultural Studies 6, no. 3 (October 1992): 471.

43 Turner, "Being Colonial/Colonial Being," 40, 50.

44 Ibid.: 40-42.

${ }^{45}$ See Bell, "We're Just New Zealanders,” 155-56;___ , "Dilemmas of Settler Belonging," 147-48; Dyson, "Construction and Reconstruction," 63; Wevers, "Being Pakeha," 2; Turner, "Being Colonial/Colonial Being," 50-52; Jane Stafford, "Going Native: How the New Zealand Settler Became Indigenous," Journal of New Zealand Literature 23 (2005): 162-73.
} 
town and country in which they were born. ${ }^{46}$ One couple looks to Maori relationships with landscape to explain the emergence of Pakeha mythologies, claiming, 'We're only now beginning to look closely at the place we're living in. The Maoris have been looking at it for centuries and their legends have long ago crept in out of the cold to be part of their lives.' ${ }^{37}$ Frame's Pakeha culture has tried to compensate for its problematic relationship with landscape with consumerism, which extends to a desire to own, transform and control landscape. ${ }^{48}$ Frame conveys cynicism at Pakeha attempts to establish belonging, as the couple state, "You have to look at something, I suppose, besides your homes, furniture and gardens." 49 Frame's treatment of Pakeha culture portrays Pakeha belonging as inauthentic.

Brian Turner articulates a different perspective in "Yokels" in Beyond, which resonates with Michael King's assertion that cultural legitimacy should be determined by commitment to New Zealand rather than ethnicity or ancestral heritage. ${ }^{50}$ After asserting an exclusive, regionalised understanding of landscape, Turner questions the relationship between cultural heritage, ethnicity and belonging. He writes:

\footnotetext{
And now it's not so much who belongs here but who owns, who's entitled, whose blood's coursing where, where lineage starts and ends, ... .
}

Crucially, he leaves the problem unsolved.

In The Shag Incident Stephanie Johnson suggests the solution is not appropriating Maori culture as a vehicle for legitimacy. Her character, Melody, chides her sister for

\footnotetext{
${ }^{46}$ Frame, The Carpathians, 44, 67, 68, 72, 125.

47 Ibid., 163-64.

${ }^{48}$ Ibid., 64-65, 72, 74, 78-79.

${ }^{49}$ Ibid., 163-64.

50 King, Being Pakeba Now, 11, 235-36, 239.

51 Turner, "Yokels," in Turner, Beyond, 56.
} 
hiring a kaumātua (Maori elder) to bless and name her child. Melody notes the preposterousness of paying a kaumātua to say the Lord's Prayer to an agnostic and atheist family in asking, 'Is it the logic here that most of us won't understand it, so that makes it all right? ${ }^{52}$ When questioned, her sister, who is depicted as flighty and prone to fads, also claims that Maori names are 'names that belong to the land. ${ }^{53}$ Melody is unimpressed and feels 'overwhelmed by the senseless, hollow trendiness of it. ... It reeks of political correctness of the worst kind; it seems insincere. ${ }^{54}$

These examples suggest that there is an ongoing conversation about Pakeha attempts to find belonging in landscape given their awareness that they are 'one kind of New Zealander alongside a prior, indigenous kind. ${ }^{55}$ Yet, within my sources, biculturalism is not a primary theme. In the next section I discuss a theme of desecration that provides an illustrative example of the challenges to relationships between landscape, spirituality and Pakeha cultural identity. While I focus on ecological tensions, in reflection of their primacy in my sources, I locate the theme within the web of identity concerns that reverberate from New Zealand's colonial history and Pakeha settler origins.

\section{Reconstructing landscape}

The ecological transformation of New Zealand's landscape that was enacted by Pakeha settlers has been described as 'one of the most comprehensive transformations of indigenous nature the world has seen'. ${ }^{56}$ James Belich claims that Pakeha settlers burnt as much, and possibly more, indigenous forest within forty years than Maori had

\footnotetext{
52 Johnson, The Shag Incident, 146.

${ }^{53}$ Ibid., 144.

${ }^{54}$ Ibid., 146.

${ }^{5}$ Bell, "Dilemmas of Settler Belonging," 148.

${ }^{56}$ Park, “A Moment for Landscape," 196.
} 
within four centuries. ${ }^{57}$ Michael King notes that a process of ecological change that took twenty centuries in Europe took only one in New Zealand. ${ }^{58}$ Geoff Park conveys the magnitude of ecological change when he states, 'When the smoke of their colonists' fires cleared at the end of the $19^{\text {th }}$ century, New Zealand had become a different country. ... Huge slices of the ancient ecosystem were missing, evicted and extinguished. ${ }^{59}$ The settlement myths that accompanied and legitimised this transformation played a key role in constructions of New Zealand nationalism and Pakeha cultural identity. In this section I discuss these myths, from their construction as a reflection of colonial glory to their repositioning as a source of postcolonial unease, to contextualise the theme of desecration I discuss in the next section.

James Belich claims that New Zealand's colonisation by Britain was facilitated by persuasive settlement myths that were disseminated in a 'crass and transparent advertising campaign' aimed at luring British migrants to New Zealand's distant and less desirable shores. ${ }^{60}$ The campaigns were centred on motifs of 'paradise,' 'progress,' and 'Britishness', which appealed to nineteenth-century British and European views of nature and empire. ${ }^{61}$ Whether settlers believed that they were sailing towards paradise or not, they arrived in a foreign landscape and had to hew a new life out of the bush. ${ }^{62}$ The rural and bush mythologies they constructed around their efforts continue to inform Pakeha cultural identity. ${ }^{63}$

${ }^{57}$ Belich, Making Peoples, 365; James Belich, Replenishing the Earth: The Settler Revolution and the Rise of the Anglo-World, 1783-1939 (Oxford: Oxford University Press, 2009), 192.

58 Michael King, The Penguin History of New Zealand (Auckland: Penguin, 2003), 24-25.

${ }^{59}$ Geoff Park, Nga Uruora: The Groves of Life, Ecology and History in a New Zealand Landscape (Wellington: Victoria University Press, 1995), 13.

${ }^{60}$ Belich, Making Peoples, 278, 279-87. See also Miles Fairburn, The Ideal Society and Its Enemies: The Foundations of Modern New Zealand Society, 1850-1900 (Auckland: Auckland University Press, 1989), 20.

${ }^{61}$ Belich, Making Peoples, 287, 292-93, 298-99, 302-04, 310-11.

${ }^{62}$ Ibid., 298.

${ }^{63}$ Keith Sinclair, A Destiny Apart, 8; Kirstie Ross, Going Bush: New Zealanders and Nature in the 20th Century (Auckland: Auckland University Press, 2008), 159, 165; Bell, “The 'Real' New Zealand,” 145-48; - Inventing New Zealand, 5, 24, 34-37; Morris, "New Zealand Spirituality: A Time for Re-

Enchantment," 187; Eveline Dürr, "Reinforcing Cultural Hegemony: Pakeha Perceptions of Brand New Zealand," Journal of New Zealand Studies 6/7 (Oct 2007/2008): 64; _—_ "Representing Purity: National Branding, Nature, and Identity in New Zealand," (paper presented at the Transformations '07: 
Keith Sinclair claims that second generation Pakeha settlers grew up 'extremely conscious' and proud that they were 'native New Zealanders' rather than English, Irish or Scottish. ${ }^{64}$ And, in looking for their roots, they looked to pioneer experiences rather than to their ancestral homes. ${ }^{65}$ Sinclair claims this and subsequent generations of Pakeha mythologised the process of remaking landscape as a struggle against the bush, adding qualities such as physical and mental determination to constructions of a national character. ${ }^{66}$ These myths endure.

Claudia Bell identifies the endurance of a 'powerful persuasive rural myth' of the 'happy rural family working together in the natural environment' in popular nostalgia. ${ }^{67}$ The mythology surrounding figures such as Sir Edmund Hillary and Barry Crump, as solitary men in tune with and mastering nature resonates with man alone narratives. ${ }^{68}$ And, Eveline Dürr's research on the impact of the '100\% Pure New Zealand' marketing campaign finds that some Pakeha cite an inherent fortitude, borne from the tests of hardship their ancestors faced in surviving an arduous migration and 'conquering' a formidable landscape, as a source of positive distinction. ${ }^{69}$

However, in the 1980s, the settlement myths that legitimised colonial processes became a focus for consternation. Some Pakeha attempted to construct new landscape

Composing the Nation: Ideas, Peoples, Histories, Languages, Cultures, Economies. The Congress of Te Whainga Aronui, The Council for the Humanities, Victoria University of Wellington, August 27-28, 2007), http://www.humanitiesresearch.net/news/ representing_purity_national_branding_nature_and_identity_in_new_zealand_1, 'Pakeha Identity and Perceptions of New Zealand's Purity'

${ }^{64}$ Sinclair, Towards 1990, 6. Sinclair's timings and focus have been challenged. See Belich, Paradise Reforged, 29; Giselle Byrnes, "Rethinking National Identity in New Zealand's History," (paper presented at the Dominion Status Symposium, Legislative Council Chamber, Parliament Buildings, Wellington, 2007), www.mch.govt.nz/dominion/byrnes.html, 'What is National Identity?'; Gibbons, “The Far Side," 8. Belich's 'recolonisation' thesis challenges Sinclair's timeframe. Byrnes and Gibbons criticise Sinclair's cultural nationalist approach to New Zealand history. In Towards 1990 Sinclair reasserts the nationalist thesis he set out in $A$ Destiny Apart but concedes he may have underestimated the endurance of the cultural attachment to Britain as 'Home'. See Sinclair, Towards 1990, 6.

65 Sinclair, A Destiny Apart, 8; — Towards 1990, 5-6.

${ }^{66}$ Sinclair, A Destiny Apart, 8-9; —_ Towards 1990, 5-6.

${ }^{67}$ Bell, "The 'Real' New Zealand," 148, 46. Belich notes that the role of the 'self-made pioneer farmer' in New Zealand's settlement is largely mythology in Belich, Making Peoples, 365, 395.

${ }^{68}$ Katie Pickles, "Kiwi Icons and the Re-Settlement of New Zealand as Colonial Space," New Zealand Geographer 58, no. 2 (2002): 9-10; Dürr, "Representing Purity," 'Pakeha Identity and Perceptions of New Zealand's Purity'; —_ "Reinforcing Cultural Hegemony": 65.

${ }^{69}$ Dürr, "Representing Purity," 'Pakeha Identity and Perceptions of New Zealand's Purity'. 
myths focussed on environmentalism..$^{70}$ An awareness of the ecological devastation caused by Pakeha settlers was not new. As I stated in the previous chapter, a theme of the mutilated bush emerged in the Late Colonial period and the destruction of landscape was key to the Provincial period theme of land and people. Beyond creative fiction, there were early voices for conservationism in New Zealand. ${ }^{71}$ For example, in Tutira: The Story of a New Zealand Sheep Farm and his ornithological books, Herbert Guthrie-Smith warned and expressed remorse for the ecological devastation he and his fellow colonists had caused. ${ }^{72}$ But while Guthrie-Smith identified 'only the voices of one or two crying in the wilderness', in the 1970s and 1980s environmentalism was propelled to a matter of collective identity and national concern. ${ }^{73}$

Augie Fleras and Paul Spoonley identify the influence of green politics in constructions of postcolonial Pakeha identities in the 1980s, as environmentalism and the protection of New Zealand's landscape replaced earlier settlement myths that justified and glorified the colonial mission. ${ }^{74}$ Successful environmental campaigns in the 1970s, the nuclear free movement in the 1980s, and New Zealand's association with international green movements via the 1985 bombing of the Rainbow Warrior helped to shape a "clean and green" image of an ecologically friendly nation, which provided Pakeha with a source of positive distinction. ${ }^{75}$ To be Pakeha was to be "green".

These new myths are subject to challenge. For example, Alex Calder identifies a 'Pakeha turangawaewae', which he describes as a 'syndrome' whereby Pakeha have tried

${ }^{70}$ Fleras and Spoonley, Recalling Aotearoa, 87.

${ }^{71}$ Belich, Paradise Reforged, 529; Park, Ngā Uruora, 69; ___ "A Moment for Landscape,” 199200.

72 See Herbert Guthrie-Smith, Tutira: The Story of a New Zealand Sheep Station, 4th ed. (Auckland: Random House, 1999); —_ Sorrows and Joys of New Zealand Naturalist (Dunedin: AH and AW Reed, 1936). Tutira was first published in 1921. 1925), vii.

${ }^{73}$ Herbert Guthrie-Smith, Bird Life on Island and Shore (Edinburgh: William Blackwood and Sons,

${ }^{74}$ Fleras and Spoonley, Recalling Aotearoa, 87.

75 Belich, Paradise Reforged, 436-40, 519, 530-31; Bell, Inventing New Zealand, 53; Eveline Dürr, "Arcadia in the Antipodes: Tourists' Reflections on New Zealand as Nature Experience," Sites: A Journal for Radical Perspectives on Culture 4 (2007): 63; ___ , "Representing Purity," 'Creating Brand New Zealand and Fostering National Identity'; __ , "Reinforcing Cultural Hegemony," 62. 
to make landscape about them. ${ }^{76}$ He claims 'Pakeha turangawaewae' is the kind of belonging Pakeha have because they do not have turangawaewae ("a place to stand”), which is unavailable to them. ${ }^{77}$ He identifies the basis of Pakeha claims to turangawaewae in the feeling that 'we have a place to stand, and we have that place because we value nature. ${ }^{, 78}$

Yet, the inclusion of a "clean and green" image in constructions of Pakeha cultural identity has been reinforced. For over a decade, a '100\% Pure New Zealand lifestyle' and a generic 'love of the land' has been successfully commodified as Tourism New Zealand has propelled carefully crafted images of New Zealand landscapes on to an international stage. ${ }^{79}$ While the promotion of New Zealand landscapes is not new, and the campaign was not intended for a domestic market, its core themes have influenced and reinforced Pakeha perceptions of their landscape and themselves. ${ }^{80}$ These new myths of landscape and identity have helped to elevate the protection of New Zealand landscapes to a national concern.

In the next section I discuss how ecological tensions are represented within my sources and identify a theme of desecration that indicates that a transformed and damaged landscape is a problematic reminder of the disjunction between Pakeha and place.

${ }^{76}$ Goldie, Fear and Temptation, 13; Alex Calder, "Blending and Belonging: Blanche Baughan and Scenic New Zealand," Journal of New Zealand Literature 23 (2005): 174.

${ }_{77}$ Calder, "Blending and Belonging: Blanche Baughan and Scenic New Zealand," 175.

78 Ibid.: 174.

${ }^{79}$ Dürr, "Representing Purity," 'Creating Brand New Zealand and Fostering National Identity'; _, "Arcadia in the Antipodes," 60; Tourism New Zealand, Pure As: Celebrating 10 Years of 100\% Pure New Zealand (2009), 10, 17, 22, 37, http://www.tourismnewzealand.com/media/106877/10 year anniversary of 100 pure new zealand campaign - pure as magazine.pdf.

${ }^{80}$ Dürr, "Arcadia in the Antipodes," 60, 65;___ "Representing Purity," "Creating Brand New Zealand and Fostering National Identity'; __ , "Reinforcing Cultural Hegemony," 60-62, 72; Bell, Inventing New Zealand, 46-49; Mark Williams, “Travels in Maoriland, 1907-1999," New Zealand Books 9 , no. 5 (1999): 2-3. 


\section{'What a change to take place within the next three-quarters of a century!'}

In his study of nature in the United States of America, Canada, Australia and New Zealand, Thomas Dunlap claims that the countries' white settler cultures are united as 'we all, still, face a common situation, seeking a place in lands now littered with the wrecks of earlier generations' hopes and dreams. ${ }^{81} \mathrm{~A}$ few of my writers imagine the hopes and dreams of Pakeha settlers, as they portray New Zealand's transformation as act as nation building. For example, in Oracles and Miracles Stevan Eldred-Grigg cites a fictional Christchurch city council publication, which proudly declares:

The land then was as it had been for, perhaps, thousands of years previously, and puny man had left no mark upon it, if one excepts the few poor scratching of native cultivations. What a change to take place within the next three-quarters of a century! $!^{82}$

And, in The Singing Whakapapa C.K. Stead's character, Hugh, looks over a river plain in wonder at 'how in just a few generations it had been transformed from a wilderness to a richly productive garden. ${ }^{83}$ Yet, these hints of glory from mastering a foreboding landscape have largely faded in favour of representations of unnaturalness and lament. Within my sources, writers articulate awareness, culpability or regret for a desecrated landscape. They depict a fragile landscape that has been irreparably damaged and is subject to ongoing threat from human, and particularly Pakeha, inhabitation.

Some writers imagine a horror in witnessing the remaking of the landscape. For example, in The Book of Secrets Fiona Kidman depicts a character leaving her house after years of seclusion. She is stunned and unsettled at the changes to the landscape, as 'the paddocks were much smoother, so neatly tailored, so sewn up with fences that she felt

\footnotetext{
${ }^{81}$ Dunlap, Nature and the English Diaspora, 316.

${ }^{82}$ Eldred-Grigg, Oracles \& Miracles, 7.

${ }^{83}$ Stead, The Singing Whakapapa, 271.
} 
disorientated and hurried home. ${ }^{84}$ Interestingly, Kidman portrays her character as a passive observer who cries out in alarm as fire threatens the trees she has made home..$^{85}$ Kidman conveys the magnitude of the transformation by describing fires raging across the bush and creating smoke that 'billowed across the ocean, so that ships far out at sea claimed to have had their way lit back to land by the glow in the sky. ${ }^{9} 6$

In "Kyeburn Diggings" in Walking on the Snow Ruth Dallas also creates distance between the transformation of New Zealand's landscape and Pakeha inhabitation. She depicts an uninhabited and desolate Central Otago landscape that bears the marks of a gold mining history. She alludes to the embracive efforts to excavate the landscape, writing:

Whether gold was found or no,

The stones are scrubbed sterile as snow, Too hot, too cold for grass to grow. ${ }^{87}$

But she refers to a nameless, historical 'Someone' who 'Has lifted every stone and knocked it clean. . . ${ }^{88}$ Dallas' portrayal of an empty landscape created by unnamed people conveys passivity and distance from the damage wrought upon the land. ${ }^{89}$ She describes Central Otago landscapes as 'sterile' or desolate in several of her poems. ${ }^{90}$ These scenes contrast with her playful representations of interactions with anthropomorphised plants and animals in a cherished domestic garden, suggesting a lack of connection to landscape in this state. ${ }^{91}$ Dallas' poem suggests that a transformed landscape invokes a past many Pakeha would rather forget.

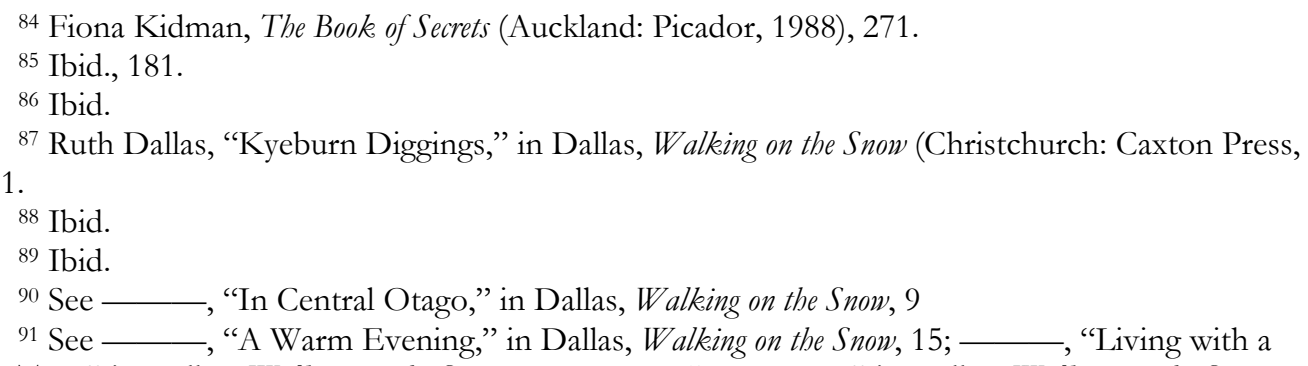


Other writers express incrimination as they depict the results of a comprehensive ecological change. They describe desecrated landscapes that lie in Pakeha settlers' wakes. For instance, culpability and regret for deforestation is evident in Allen Curnow's choice in "A Raised Voice" in The Loop in the Kauri Road to use the word 'rape' to describe the clearing and conversion of northern Kauri forests into furniture and buildings. ${ }^{92}$ His reference to the destruction of kahikatea forests to make butter boxes, for shipping back to England, further conveys the magnitude and a senselessness of the loss. In The Book of Fame Lloyd Jones evokes fragility and inevitability in contrasting the trees in England with those in 'cleared land around Taranaki' that 'bear the shape of surrender'. ${ }^{93}$ Brian Turner also reflects upon deforestation in "The Fat Boy" in Beyond, as he wonders, 'Is there a kauri left in the forest / big enough for the fat boy to hide behind?'94

In "The Boy, the Bridge, the River" and "End" in The Boy, the Bridge, the River Vincent O’Sullivan depicts New Zealand's pastoral landscape as unnatural, as he describes its artificial green hue. His characters refer to pastoral landscapes as former swampland that has been 'cut up' and fertilised into unnaturally green sections. ${ }^{95} \mathrm{~A}$ character in "The Boy, the Bridge, the River" likes to imagine what the land was like before humans irreparably changed it. ${ }^{96}$ Other writers create similar scenes. For instance, in "Just Like This Train" in Pieces of Music Michael Jackson suggests unnaturalness by depicting the Manawatu plains as the landscape lost. He describes the farmland as 'drained swamplands, flax with seedpods like charred matchsticks'. ${ }^{97} \mathrm{My}$ writers also convey the extent of New Zealand's ecological transformation by

\footnotetext{
92 Allen Curnow, "A Raised Voice," in Curnow, The Loop in Lone Kauri Road: Poems, 1983-1985

(Auckland: Auckland University Press; Oxford University Press, 1986), 10.

93 Jones, The Book of Fame, 95.

94 Brian Turner, "The Fat Boy," in Turner, Beyond, 44.

${ }^{95}$ Vincent O'Sullivan, "End," in O'Sullivan, The Boy, the Bridge, the River, 82; __ , "The Boy, the Bridge, the River," in O'Sullivan, The Boy, the Bridge, the River, 105.

96 O’Sullivan, "The Boy, the Bridge, the River," 105.

${ }^{97}$ Michael Jackson, “Just Like This Train," in Jackson, Pieces of Music, 90.
} 
suggesting Pakeha tried to remake all landscapes, even those feasibly out of their control. For example, in "Writing Home, (7)" in It Has No Sound and it is Blue Dinah Hawken refers to attempts to 'tame' Mount Taranaki by renaming it.98

These suggestions of culpability and remorse are not confined to the actions of a colonial past. There are also indications of regret for the continuing desecration of landscape, as land development is depicted as hurting the land. To illustrate, in "For a Children's L.P (Ecology)" in Quesada C.K. Stead offers a haunting tale for children. He writes:

Look there - down in the bay Where a blue heron is wading Dump trucks and bulldozers Are filling the edge with clay. ${ }^{99}$

He exhorts them to 'Think of the lives that stopped / Six feet under the clay.' 100 Peter Hooper also offers a tale of warning in People of the Long $W$ ater in which he presents a radically different reality in an identifiably but irreparably transformed New Zealand landscape. ${ }^{101}$ Cilla McQueen expresses her opposition to ongoing land development in "Words Fail Me" in Homing In by referring to forestry trucks as 'logsnatchers angry growling."102 And, in "Brothers" in Beyond Brian Turner suggests the landscape is alive and aware of threat, as he describes leaves chattering 'about how trees would soon / be felled and chipped / and sent overseas. ...'103

In Ngā Uruora: The Groves of Life, Ecology and History in a New Zealand Landscape Geoff Park claims, 'How we inhabit a place can be the most telling expression of how

\footnotetext{
${ }^{98}$ Dinah Hawken, "Writing Home (7)," in Hawken, It Has No Sound and Is Blue, 29.

${ }^{99}$ Stead, "For a Children's L.P (Ecology)," in Stead, Quesada, 34.

100 Ibid.

101 Peter Hooper, People of the Long Water (Dunedin: McIndoe, 1985).

102 McQueen, "Words Fail Me," 42.

103 Brian Turner, "Brothers," in Turner, Beyond, 35.
} 
we sense its worth, our intention for it and our connection with it'. ${ }^{104}$ The depictions of a landscape scarred by Pakeha hands that I have discussed in this section suggest that many Pakeha find their inhabitation wanting. The representations of the landscape as unnatural, the expressions of regret for deforestation and the disquiet over ongoing land development give shape to a theme of desecration that suggests a transformed landscape is a problematic reminder of the disjunction between Pakeha and place. In The Future Eaters Tim Flannery wonders if New Zealand's amenable landscape has made it easier for Pakeha to forget that they 'do not fit comfortably' here. ${ }^{105}$ The theme of desecration that I have located and articulated suggests that this is not the case. Rather, it suggests that many Pakeha are aware of the conditions of their inhabitation.

While the rural and bush mythologies that legitimised a colonial past have faded in favour of the myths of a clean and green nation, the landscape tells a different story. Visible signs of ecological degradation invoke the violence involved in remaking New Zealand into home. With the increasing currency of environmentalism and cultural importance of New Zealand's internationally revered landscapes, a desecrated landscape is a source of instability, as the blame for ecological devastation falls mostly on Pakeha hands. Pakeha have damaged the landscape they call home and the damage done is a reminder of the disjunction between Pakeha and place. The ongoing degradation of landscape is a betrayal of the identities Pakeha have forged within it. ${ }^{106}$

Janet Frame articulates the cultural repercussions of a systematic remaking of landscape and demonstrates the problems of Pakeha belonging. In Living in a Maniototo she depicts landscape as a both a saviour and a jailer, as the focus for an obsession with consumption and the source of cultural discontent. ${ }^{107}$ Frame's fictional New Zealand

104 Park, Ngā Uruora, 21.

105 Tim Flannery, The Future Eaters: An Ecological History of the Australasian Lands and People (Chatswood, N.S.W.: Reed Books, 1995), 397.

106 King, The Quest for Identity, 21. King makes this claim.

${ }^{107}$ Frame, Living in the Maniototo, 22, 31, 131-32, 141. 
suburb is a site of loss, as its residents are pitted against the landscape they have consumed and transformed in an attempt to transform themselves. ${ }^{108}$ Frame describes the transformation as unnatural, with the vestiges of indigenous forest pushed to edges of existence by a community who are haunted by the damage they have wrought. ${ }^{109}$ The outcome of this destruction is a sickness the community now suffers. ${ }^{110}$ She writes, 'The children are restless, with a sense of loss, as if they had truly been children of native forest which, like a father, had abandoned them by dying.'111 Frame's Pakeha have transformed the landscape into home and discovered that they do not belong.

In the next chapter I draw the themes of belonging and desecration together to identify complex and contested spiritualities of landscape that are manifestations of the problems of Pakeha belonging.

108 Ibid., 21-24.

109 Ibid.

110 Ibid., 21, 23.

111 Ibid., 21. 


\section{CHAPTER FIVE}

\section{CONCLUSION}

Over the past three chapters I have sketched the contours of the richly textured spiritual discourse I drew from representations of spirituality and landscape in eightyseven works of Pakeha literary fiction by fifty-four writers and published over a thirtyfour year period. The representations of landscapes, spiritualities and identities that I have discussed suggest many possibilities and share some common themes. In this chapter I draw together the spiritual strands that I have articulated in the past three chapters.

I began this thesis by citing recent research reported in New Zealand Listener that finds New Zealanders identify their 'relationship with the land', which is described as 'spiritual, even soulful', as the defining feature of 'New Zealandness'. 'That research supports the centrality of landscape in relatively recent articulations of "New Zealand" or "Kiwi spiritualities". It resonates with other popular assertions. I found these claims of our spiritual relationships with landscape intriguing for a society that is described as 'eminently secular' and particularly in relation to Pakeha, who have been categorised by their spiritual aridity rather than their spiritual predispositions or unity. ${ }^{2}$ They suggested spiritual concerns that are not captured by empirical measures or discourse on the histories and probable futures of New Zealand's religious institutions. And, they signalled an interesting development in the complex relationships between Pakeha and landscape.

In order to explore these possibilities I outlined an understanding of spirituality that took into account its informality, individuality and distance from traditional forms

\footnotetext{
${ }^{1}$ Clifton, "Choice, Bro," 14.

2 Matheson, "Myth of a Secular New Zealand," 177; Morris, "New Zealand Spirituality: A Time for Re-Enchantment,” 185.
} 
of religion. As I discussed in Chapter Two, my understanding was informed by New Zealand's secularity, Charles Taylor's dismantling of “empty” secularity, Thomas Luckmann's conception of transcendence, and awareness that a spiritual reading of literary fiction is an act of construction. These considerations led me to broadly define spiritualities with a landscape focus, as a plurality of beliefs, values and experiences centred on landscape that enrich and orient life and are likely to include this- or otherworldly transcendence that point(s) people to other dimensions, the past, each other or themselves. I surmised that such spiritualities would be represented as sources or foci for feelings of fulfilment, clarity, communion, fear or joy.

Over the past three chapters I have articulated the rich spiritual current that I identified with this definition as my guide. The examples I have given have variously represented landscape as a site and foci for experiences of transcendence, reverence, revelation and transformation. I have demonstrated how Pakeha writers depict landscape as fulfilling spiritual needs and desires, as a reminder of prior spiritual experiences and a conduit for connections with spiritual forces and figures. I have described the ways landscape is represented as a vehicle for exploring personal and collective histories, maintaining meaningful interpersonal relationships and as a point of identification for participation in collective life. These are spiritualities of landscape. They are relationships between person and place that shape identity, how people see others, their place in the world and their possibilities for the future. In the words of Charles Taylor, landscape is represented as a source of fullness; it is a focus for spiritualities that enrich and orient lives.

Many of the representations that I have discussed articulate Pakeha attempts and assertions of belonging. I began Chapter Three with representations of spiritualities of landscape by four Pakeha writers in six works that spanned my timeframe. The writers variously drew landscape into expressions of identities inscribed, reflected, 
realised and transformed in personal, spiritual attachments to place. From this introduction I identified common themes of belonging and home that I expanded upon by discussing the locations depicted as sites or foci for spirituality in a greater number of works. The spiritual landscapes that I have located are predominantly in or near where many Pakeha live and play. These landscapes are inhabited, bear the marks of that inhabitation and are sites of every day or weekend experience. They are coastal hills and remnants of the bush that frame cities and suburbs, harbour views from much loved gardens, a perpetually changing coastline and pervasive mountains. While some writers draw the country's picturesque scenes into evocations of the sublime, others use spiritual vocabularies and representations of transcendence to articulate and, sometimes, assert lives lived in relation to place. They depict picturesque landscapes as ordering and symbolising the identities shaped by living within their sight or shadow.

The spiritual expressions within these local scenes portray different experiences of belonging. This sense of belonging is realised and strengthened by being at home. Thus, Maurice Gee's protagonist in Going West locates his identity in the rush of feeling he has for Auckland's coast. Cilla McQueen offers fragments of a life shaped by an intimacy with a particular place. Janet Charman, Brian Turner and Kendrick Smithyman convey the necessity and reward of knowing landscape. And, Anne Kennedy and Damien Wilkins demonstrate how realising and constructing a sense of belonging in landscape can change how people see themselves.

In the last chapter I demonstrated how landscape, and a sense of belonging gained from relationships with landscape, is represented as a focus for collective experience. I illustrated three ways landscape is portrayed as a vehicle for exploring and maintaining the relationships people have with others, across time, distance and dimension, that shape how they see themselves. These relationships are interpersonal or imagined, as shared experiences in landscape provide points of identification for 
feelings of togetherness or participation in community. They direct people to their personal and collective histories, and point them towards a sense of home while they are away. Thus, Jenny Bornholdt and Glenn Colquhoun look to the landscape that surrounds them and see memories of those loved and lost. Lauris Edmond and Dinah Hawken draw comfort from imagining and holding on to fragments of home while they are far away. And, Michael Jackson and C.K. Stead identify landscape as a way to access and understand the people from whom they descend.

These representations articulate the importance of belonging or feeling "at home" to personal and collective identities. They identify relationships with landscape as a way people explore and express their sense of themselves. While the representations that I have identified are plural, they suggest many Pakeha locate and articulate how they perceive themselves, their place in this country and their relationships to others near and far in dynamic and developing relationships with landscape. These relationships are a ground for personal, collective and spiritual lives. This finding illuminates the spiritual possibilities that are obscured by narrow conceptions of religion, spirituality and secularity. It supports the inclusion of relationships with landscape in conceptions of Pakeha spiritual identities. But the spiritual themes that I have located indicate relationships between landscape, spirituality and Pakeha identity are more complex and contested than is conveyed by popular avowals of a 'shared love of the land'. ${ }^{3}$

In Chapter Four I discussed the role of landscape in constructions of Pakeha cultural identity, with a focus on the settlement myths that supported and legitimised a process of rapid ecological change. In a brief overview I noted that images of New Zealand as a paradise were sold to potential migrants to encourage them to a remote and undeveloped land. The ecological transformation they enacted in remaking New

\footnotetext{
${ }^{3}$ Caroline Courtney, "Religion: Who Needs It?"
} 
Zealand into something like home was subsequently mythologised as an act of nation building and source of colonial identity. In the reconstructions of Pakeha cultural identity from the 1980s, the centrality of landscape myths that legitimised colonisation were replaced by myths of an ecologically friendly nation with guardianship over a uniquely beautiful land. While the landscape myths have changed, landscape remains at the heart of constructions of Pakeha cultural identity.

Yet, the relationships between landscape and Pakeha cultural identity are fraught, as Pakeha are aware that their belonging is always problematic. Pakeha settler origins, with their legacies of migration, colonisation and transformation, mean Pakeha are not easily "at home". Especially since the crisis of Pakeha cultural identity, landscape is a focus for contestations that reverberate from New Zealand's colonial histories, bicultural present and the uncertainties of a shared future. Since the 1980s Pakeha have attempted to reconstruct a sense of belonging in a damaged landscape with the awareness that Maori are tangata whenua. As I discussed in Chapters One and Four, both Maori and Pakeha have challenged these attempts. Criticisms of the inclusion of relationships with landscape in constructions of Pakeha cultural identity demonstrate that many Pakeha are denied and deny themselves a sense of belonging in the landscapes they call home.

As I illustrated with examples by Stephanie Johnson, Janet Frame and Brian Turner, there is evidence of ongoing discourse on biculturalism within my sources. These writers voice different perspectives on issues of cultural legitimacy, appropriation and instability. They are united in depicting landscape as a burden for Pakeha. Representations of Pakeha as plagued by the brevity of their occupation confirm that many Pakeha are aware that the landscape is not theirs. And, as a result, they cannot easily own themselves. In Portrait of an Artist's Wife Barbara Anderson suggests this is a burden many Pakeha would rather forget. But due to personal and collective histories 
like that described by Anderson's character, in which her husband's grandfather bought land from 'the local Maoris' and asked how he could have determined ownership 'once, and never again', Pakeha cannot avoid the challenge to their inhabitation. ${ }^{4}$

In Chapter Four I identified a theme of desecration as an illustrative example of the contestations that plague Pakeha belonging. Representations of awareness, culpability and regret for the effects of a process of comprehensive ecological change suggest that many Pakeha believe the landscape is worthy and in need of protection but has been damaged by Pakeha hands. Thus, Allen Curnow and Janet Frame describe this transformation in criminal terms. Michael Jackson and Vincent O’Sullivan depict landscape as charred and unnaturally green. Brian Turner and Cilla McQueen convey remorse for continuing land development that stems from New Zealand's primary industries. And, Fiona Kidman imagines the horrors of witnessing the deforestation of New Zealand's past.

The theme of desecration reflects the reach of international environmental movements that influenced constructions of Pakeha cultural identity in the 1980s. And, it reflects the increasing importance of an internationally celebrated landscape as a source of positive distinction for Pakeha and other New Zealanders. Problematically, it also identifies landscape as a reminder of the disjunction between Pakeha and place. The theme of desecration suggests that the increasingly visible degradation of New Zealand's landscape invokes the violence of Pakeha attempts to remake the country into a better version of a distant home. The transformation of landscape and centrality of the myths that surround it to constructions of Pakeha cultural identity are now sources of considerable unease. Pakeha bear the responsibility for the damage wrought upon the landscapes they want to call to home.

Former Minister for the Environment, Simon Upton, articulates the lacuna in

\footnotetext{
${ }^{4}$ Anderson, Portrait of the Artist's Wife, 38-39.
} 
Pakeha identity caused by the dissonance between Pakeha and place. He conveys both the fragility of the landscape and the sense of belonging Pakeha are constructing within it. In response to Marilyn Waring turning to New Zealand landscapes to describe her identity, he states:

If people are the way their land and air is, we've done much to transform it in a way that has pushed the indigenous biota to the margins of our view.... The pakeha landscape is a pastoral idyll imposed with great violence on a completely different and ancient ecology. ${ }^{5}$

He explains that he calls himself European or 'an English-speaking European, resident in the southwest Pacific' rather than Pakeha, as 'my attachment is to a landscape that has been recast as a neo-Europe. ${ }^{6}$ He reasserts his point by looking to his childhood home and seeing that 'Ngaruawahia in name is Newcastle in form'. ${ }^{7}$ Upton's claims convey the instability caused by Pakeha awareness that they 'are not the way their land is'. ${ }^{8}$ Upton does not belong anywhere. He is not European, nor is he unproblematically from the Pacific or New Zealand. He remains a "resident" far from an ancestral home. His sense of identity is suspended some place between.

The richness and variety of spiritual expression that I have found indicates that many Pakeha explore, assert and inscribe their unfolding personal and collective identities in relationships with landscape. Representations of transcendence and reverence in local landscapes, and depictions of lives transformed, enriched and oriented through relationships with place, convey the importance of belonging to identity. But articulations of dissonance between Pakeha and place illuminate the problems that sit at the heart of relationships between landscape, spirituality and Pakeha identity. Legacies of migration, colonisation and transformation mean Pakeha cannot

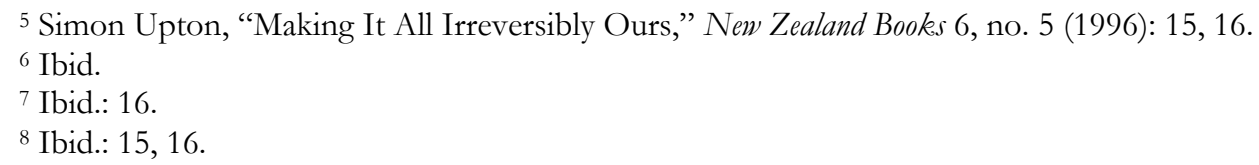


easily construct their identities by being at home. The themes of belonging and desecration give shape to spiritualities that are fragmented by the problems of Pakeha belonging.

The portrayals of spirituality in landscape that I have identified do not suggest the creation or transplantation of "nature spiritualities" in New Zealand soil or a spiritual revival focussed on landscape. Nor do they suggest a straightforward relocation of religious desire from the public to the private sphere. Rather, they are spiritualities that are borne from lives lived in relation to place. As I discussed in Chapter Two, these attributes reflect the flavour of New Zealand's secularity. Relationships with landscape are depicted as fulfilling some spiritual needs and desires but they do so inside, alongside and outside other forms of belief. And, as suggested by the themes of belonging and desecration, these attributes are shaped by the problems of Pakeha belonging. Spiritualities of landscape cannot be straightforward constructions of spirituality in landscape as Pakeha are denied straightforward relationships between person and place.

Yet, the problems of Pakeha belonging complicate rather than negate the need or attempts by Pakeha to identify with the landscapes they inhabit. The depictions of desecrated landscapes sit alongside rather than rescind articulations of identities realised and unfolding in relation to place. Indeed, representations of landscapes scarred by Pakeha hands signal an engagement with the complexities of New Zealand landscapes, which are sometimes stunningly beautiful, sometimes irreparably damaged, and sometimes a haunting reminder that Pakeha do not easily fit. The theme of desecration adds depth to spiritual and landscape discourse as it further signals a focus on experiences of belonging rather than a romantic return to an imaginary past.

The complexity and contestability of the spiritual representations that I have explored in this thesis are manifestations of the problematic relationships between 
Pakeha and place. The problems of landscape are the problems of Pakeha cultural identity. The instability and uncertainty caused by biculturalism and the ecological impact of a settler past is not easily solved. There are more questions than answers within my sources and nothing that resembles accord. But the stories and poems offer reflections of a developing landscape discourse that depicts unfolding relationships between Pakeha and place.

The development of the discourse is evident in the changes to literary landscapes. In Chapter Three I demonstrated that some Pakeha writers have reimagined the bush of New Zealand's ecological and literary past in landscapes that are closer to home. This development illuminates the local, global and antecedent influences on Pakeha literature and constructions of landscape. Earlier Pakeha writers bestowed landscape themes that were shaped by nineteenth-century European views of nature projected onto and changed by the particularities of local geography. This inheritance is evident in the examples of a romantic gaze on the picturesque and the sublime, which I noted in Chapter Three. And, it endures in the fragments of a romanticised and foreboding bush, which was mythologised by earlier Pakeha writers. Yet, the bush of Charlotte Randall, Mary McCallum or Maurice Gee is not the bush of the Early- and Late Colonial or Provincial periods. Literary landscapes have changed as Pakeha have changed. These developments have local and global origins.

The shifting focus to local landscapes, which I established in Chapter Three, is influenced by international literary trends, such as a move towards domestic poetry from the 1960s. ${ }^{9}$ It reflects the shifting aims of Post-provincial period writers, who 'write less insistently as New Zealanders' than their literary antecedents. ${ }^{10}$ And, it resonates with the concerns of a mostly urban and suburban society. ${ }^{11}$ Yet, the fading

\footnotetext{
9 Jones, "Versions of the Dream," 203; Caffin, "Poetry, Part Two," 466.

${ }_{10}$ Calder, "Unsettling Settlement," 166.

11 Jones, "Versions of the Dream," 202-04.
} 
of the bush as a wilderness in favour of representations of refuge or threat at the edge of town or over the back fence also reflects how Pakeha culture and its literature has been shaped by the particularities of New Zealand's geography and experiences of living here. Pakeha writers do not need to depict the bush as a wilderness, as 'Nature comes close in'. ${ }^{12}$ There are landscapes for moments of transcendence or revelation in and near in the areas where Pakeha live and play. For example, within an hour's drive from the main shopping street in Auckland, one can be on the beach where The Piano was filmed. Pakeha literary fiction is a hybrid literature that reflects a hybrid culture that is under construction and developing by living here.

As voices for Pakeha spiritualities and identities, Pakeha writers are part of this construction. One of the main assumptions of this thesis was that creative fiction can tell us something about the culture it is created within. In Chapter One, I drew support from Stuart Hall's identification of creative representations, such as cinema and creative fiction, as forms of discourse that 'enable us to discover places from which to speak. ${ }^{13}$ Narrowing my scope, I acknowledged the heightened role New Zealand's creative writers have in articulating Pakeha spiritualities and identities. Pakeha writers engage with matters of identity in determining what makes a Pakeha character believable, what resonates and what seems strange. They create a discourse through which Pakeha and others may see themselves. I surmised that their stories and poems would offer fragments and reflections of spiritualities that are not easily accessible in a society with few public voices for religion or spirituality.

The voices I have found are plural. They offer astute observations, dim reflections, and social and cultural commentary in representations that seem familiar and those that do not. I acknowledge that creative fiction is one form of expression.

\footnotetext{
${ }^{12}$ Denys Trussell, "Nature and the Pakeha," in Trussell, The Expressive Forest: Essays on the Arts and Ecology in Oceania (Auckland: Brick Row Publishing, 2008), 22.

${ }^{13}$ Hall, "Cultural Identity," 245.
} 
Different stories will be told using different methodologies, a different selection of texts and timeframe, or by reading creative fiction through a different lens. Yet, the richness and currency of spiritualities and landscape themes that I have detected and articulated in this thesis supports my method. Pakeha writers engage with the complexities of Pakeha spiritualities and identities that reverberate from the past, destabilise the present and define a shared future.

In reviewing eighteen coffee table books on New Zealand landscape, Tom Brooking is moved to ask, 'But where are the people?' ${ }^{14}$ From reviewing each book he concludes that New Zealanders like pictures of their country and like them 'problem free, light, and clean,' which 'conceals extraordinary human effort, massive destruction of verdant rain forest and hefty application of all kinds of chemicals which pollute the waterways while creating an artificial greenness. ${ }^{15}$ Rather than looking upon New Zealand's ecological transformation as something to be hidden away, Brooking claims these histories of landscape 'infuse it with meaning. ${ }^{16}$ He states, 'There is, therefore, a compelling need to provide some depth to a very two-dimensional picture by revealing what is underneath and behind the current look of the country. ${ }^{17}$

My findings in this thesis identify Pakeha writers as a source of such depth. Their representations of spiritualities of landscape tell the histories of inhabitation and indicate that complex and contested spiritualities comprise the third dimension. Such spiritualities are unlikely to be captured by empirical measures. They are fragmented and plural; unnamed and unpractised. For some Pakeha they are a pull of the land felt when they are away from home, catch sight of a familiar mountain or stand on a constantly changing coast. Or, they mean that the Green Party's use of a spiritual vocabulary in thanking New Zealanders for helping to protect our 'sacred' landscape does not seem

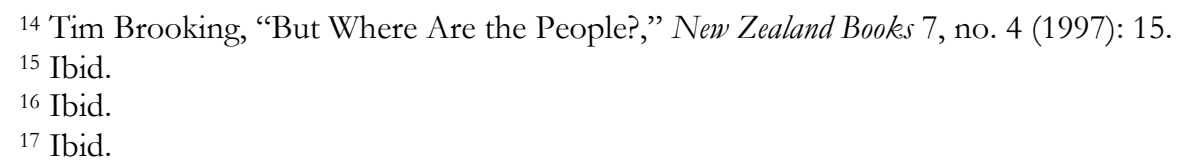


out of place. ${ }^{18}$ For others, they ground how they see themselves, each other and their connections with something beyond. These spiritualities sit alongside other collective experiences, such as participation in Anzac Day, that make up Pakeha personal, collective and spiritual lives. Yet, their complexity and fragility indicates that they are manifestations of the problems of Pakeha belonging. And, as such, they tell us less about the landscape than they do about ourselves.

${ }^{18}$ Metiria Turei, The Green Party of Aotearoa New Zealand, "The Ultimate Earth Day Present," Apr 22, 2010, http:/ /www.greens.org.nz/press-releases/ultimate-earth-day-present. 


\section{POSTSCRIPT}

\section{'the cloak of before, the wrench / of beyond'}

Traditional religious themes no longer have great resonance in New Zealand. As practice and belief in traditional forms of religion fades, the country's religious institutions tell us less and less about Pakeha spiritual lives. But this does not mean there are not significant levels of spiritual concern. The concerns I have chosen to explore in this thesis are about landscape. The literary representations of landscape and spirituality that I have found indicate that many Pakeha locate their personal, collective and spiritual identities in relationships with landscape. Such relationships ground how many Pakeha perceive themselves, their place in this country and their relationship to others near and far. Yet, my findings indicate that Pakeha constructions of spirituality in landscape are complicated by the problems of Pakeha belonging. They are manifestations of the complexity and contestability of Pakeha cultural identity.

The problems of belonging put Pakeha in concert with other white settler cultures whose identities are destabilised by histories of transplantation and colonisation. These legacies suspend white settler identities between two countries and two other peoples; they are not easily "at home". There are also issues specific to Pakeha and New Zealand. Biculturalism has made the disjunction between Pakeha and place increasingly clear. As they do not own the land, it is difficult for Pakeha to own their sense of themselves. In an internationally revered landscape, Pakeha are culpable for ongoing, comprehensive ecological change. They have damaged the landscape they call home. This dissonance between Pakeha and belonging creates a gulf in Pakeha identity.

The complex and contested spiritualities that I have identified in this literary study are manifestations of this gulf between people and place. They stand alongside 
other manifestations, such as public ambiguity over Waitangi Day, the embrace of Anzac Day to express collective spirit, and passionate nationalised attempts to protect or appear to protect remnants of indigenous flora and fauna. Spiritualities of landscape cast light on these anomalies by illuminating the desires and problems of belonging that are at the heart of Pakeha cultural identity. This literary study, using public sources, shows that these problems are not unknown however difficult they are to articulate.

The discourse that I have found is healthy and worthwhile, as it articulates the possibilities and problems of Pakeha identities and the histories that define them. The changing themes and foci over the period 1975 to 2009 that I have detected and articulated demonstrate the dynamic and developing nature of our landscapes, spiritualities and identities. This is an ongoing conversation. Brian Turner gives voice to the pull and pale of belonging in landscape that lies at its heart. He writes:

You have to be here, you have to feel the deep slow surge of the hills, the cloak of before, the wrench of beyond....

Such voices are important, as stories of landscape are the stories of Pakeha identity. 


\section{APPENDIX}

\section{PRIMARY SOURCES}

Adcock, Fleur. Selected Poems. Oxford: Oxford University Press, 1983.

Anderson, Barbara. Portrait of the Artist's Wife. Wellington: Victoria University Press, 1992.

Bornholdt, Jenny. The Rocky Shore. Wellington: Victoria University Press, 2008.

Charman, Janet. Cold Snack. Auckland: Auckland University Press, 2007.

Chidgey, Catherine. In a Fishbone Church. Wellington: Victoria University Press, 1998.

Colquhoun, Glenn. Playing God. Wellington: Steele Roberts, 2002.

Cranna, John. Visitors. Pacific Writers Series. Auckland: Heinemann Reed, 1989.

Curnow, Allen. The Bells of Saint Babel's: Poems 1997-2001. Auckland: Auckland University Press, 2001.

- Continuum: New and Later Poems, 1972-1988. Auckland: Auckland University Press, 1988.

- An Incorrigible Music: A Sequence of Poems. Dunedin: Auckland University Press, 1979.

- The Loop in Lone Kauri Road: Poems, 1983-1985. Auckland: Auckland University Press / Oxford University Press, 1986.

- You Will Know When You Get There: Poems 1979-81. Auckland: Auckland University Press / Oxford University Press, 1982.

Dallas, Ruth. Walking on the Snow. Christchurch: Caxton Press, 1976.

DeGoldi, Kate. The 10pm Question. Dunedin: Longacre Press, 2008.

Duckworth, Marilyn. Disorderly Conduct. Auckland: Hodder and Stoughton, 1984.

Edmond, Lauris. Selected Poems. Auckland: Oxford University Press, 1984.

Eldred-Grigg, Stevan. Oracles \& Miracles. Auckland: Penguin, 1987.

Farrell, Fiona. The Skinny Lomie Book. Auckland: Penguin, 1992.

Fletcher, Beryl. The Word Burners. Wellington: Daphne Brasell Associates, 1991.

Frame, Janet. The Carpathians. 1988. Reprint, Auckland: Vintage, 2005. 
—. The Goose Bath: Poems. Auckland: Vintage, 2006.

_. Living in the Maniototo. 1981. Reprint, London: Women's Press, 1991.

French, Anne. All Cretans Are Liars. Auckland: Auckland University Press, 1987.

Gee, Maurice. Blindsight. Auckland: Penguin, 2005.

—. The Burning Boy. Auckland: Viking, 1990.

—. Going West. Auckland: Viking, 1992.

—. Live Bodies. Auckland: Penguin, 1998.

—. Meg. London; Auckland: Faber / Penguin, 1981.

- Plumb. London; Boston: Faber and Faber, 1978.

Grimshaw, Charlotte. Opportunity. Auckland: Vintage, 2007.

Hawken, Dinah. It Has No Sound and Is Blue. Wellington: Victoria University Press, 1987.

Hooper, Peter. People of the Long Water. Dunedin: McIndoe, 1985.

Ireland, Kevin. Literary Cartoons. Auckland: Islands / Hurricane, 1977.

Jackson, Michael. Latitudes of Exile: Poems 1965-1975. Dunedin: John McIndoe, 1976.

—. Pieces of Music. Auckland: Vintage, 1994.

-Wall. Dunedin: McIndoe, 1980.

Jagose, Annamarie. Slow Water. Wellington: Victoria University Press, 2003.

Johnson, Andrew. How to Talk. Wellington: Victoria University Press, 1993.

Johnson, Louis. Fires and Patterns. Milton, QLD: Jacaranda, 1975.

Johnson, Stephanie. The Shag Incident. Auckland: Vintage, 2002.

Jones, Lloyd. The Book of Fame. Auckland: Penguin, 2000.

—.Mr Pip. Auckland: Penguin, 2006.

Joseph, M.K. A Soldier's Tale. Auckland: Collins, 1976.

The Time of Achamoth. Auckland: Collins, 1977.

Keith, Sheridan. Zoology. Auckland: Penguin, 1995.

Kennedy, Anne. Sing Song. Auckland: Auckland University Press, 2003. 
Kidman, Fiona. The Book of Secrets. Auckland: Picador, 1988.

—. The Captive Wife. Auckland: Vintage, 2005.

Knox, Elizabeth. The Vintne's Luck, Limited Edition. Wellington: Victoria University Press, 2008.

Leggott, Michele. DIA. Auckland: Auckland University Press, 1994.

Loney, Alan. Dear Mondrian. Christchurch: Hawk Press, 1976.

Manhire, Bill. How to Take Off Your Clothes at the Picnic. Wellington: Wai-te-ata Press, 1977.

—. Lifted. Wellington: Victoria University Press, 2005.

—. Milky Way Bar. Wellington: Victoria University Press, 1991.

—. My Sunshine. Wellington: Victoria University Press, 1996.

- Zoetropes: Poems, 1972-82. Wellington: Port Nicholson Press, 1984.

Marriner, Craig. Stonedogs. Auckland: Random House, 2001.

Marshall, Owen. Harlequin Rex. Auckland: Vintage, 1999.

McCallum, Mary. The Blue. Rosedale, N.Z.: Penguin, 2007.

McCauley, Sue. Other Halves. New York: Penguin, 1985.

McQueen, Cilla. Benæina. Edited by Iain M. Lonie. Dunedin: John McIndoe, 1988.

—. Berlin Diary. Dunedin: John McIndoe, 1990.

—. Homing In. Dunedin: John McIndoe, 1982.

Middleton, O.E. Selected Stories. Dunedin: John McIndoe, 1975.

Nannestad, Elizabeth. Jump. Auckland: Auckland University Press, 1986.

O'Sullivan, Vincent. The Boy, the Bridge, the River. Dunedin: John McIndoe, 1978.

—. Dandy Edison for Lunch, and Other Stories. Dunedin: McIndoe, 1981.

- Let the River Stand. Auckland: Penguin, 1993.

—. Nice Morning for It, Adam. Wellington: Victoria University Press, 2004.

—. Seeing You Asked. Wellington: Victoria University Press, 1998. 
Perkins, Emily. Novel About My Wife. London: Bloomsbury, 2008.

Randall, Charlotte. Dead Sea Fruit. Auckland: Secker \& Warburg / Reed Books, 1995.

Shadbolt, Maurice. The Lovelock Version. London: Hodder and Stoughton, 1980.

- Season of the Jew. London: Hodder and Stoughton, 1986.

Smither, Elizabeth. The Lark Quartet. Auckland: Auckland University Press, 1999.

—. A Pattern of Marching. Auckland: Auckland University Press, 1989.

Smithyman, Kendrick. Stories About Wooden Keyboards. Auckland: Auckland University Press, 1985.

Stead, C.K. All Visitors Ashore. The Godwit Collection. Auckland: Godwit, 1994.

_. Quesada: Poems, 1972-74. Auckland: The Shed, 1975.

—. The Singing Whakapapa. Auckland: Penguin, 1994.

Turner, Brian. Beyond: Poems. Dunedin: McIndoe, 1992.

—. Just This. Wellington: Victoria University Press, 2009.

—. Ladders of Rain. Dunedin: John McIndoe, 1978.

Wedde, Ian. Dick Seddon's Great Dive. Auckland: Islands / Robin Dudding, 1976.

- Spells for Coming Out: And Drawings by Joanna Paul. Auckland: Auckland University Press, 1977.

Wells, Peter. Dangerous Desires. Pacific Writers Series. Auckland: Reed, 1991.

Wilkins, Damien. The Miserables. Wellington: Victoria University Press, 1993. 


\section{WORKS CITED}

Ahdar, Rex. "Reflections on the Path of Religion-State Relations in New Zealand." Brigham Young University Law Review 2006, no. 3 (2006): 619-60.

Ahdar, Rex, and John Stenhouse. Introduction to God and Government: The New Zealand Experience, edited by Ahdar and Stenhouse, 9-20. Dunedin: University of Otago Press, 2000.

Albanese, Catherine. Nature Religion in America: From the Algonkian Indians to the New Age, Chicago History of American Religion. Chicago: University of Chicago Press, 1990.

Anderson, Barbara. Portrait of the Artist's Wife. Wellington: Victoria University Press, 1992.

Anderson, Benedict. Imagined Communities: Reflections on the Origin and Spread of Nationalism. Revised and extended ed. London: Verso, 1991.

Asad, Tahal. Formations of the Secular: Christianity, Islam, Modernity. Stanford, California: Stanford University Press, 2003.

Barnett, Sarah. "Welcome to Our World: What Recent Arrivals Think of New Zealanders." New Zealand Listener, July 3-9, 2010, 19-22.

Baughan, Blanche. "A Bush Section." In The New Place: The Poetry of Settlement in New Zealand, 1852-1914, edited by Harvey McQueen, 195-201. Wellington: Victoria University Press, 1993.

Belich, James. Making Peoples: A History of the New Zealanders from Polynesian Settlement to the End of the Nineteenth Century. Auckland: Allen Lane, 1996.

- Paradise Reforged: A History of the New Zealanders from the 1880s to the Year 2000. Auckland: Allan Lane / Penguin, 2001.

- Replenishing the Earth: The Settler Revolution and the Rise of the Anglo-World, 17831939. Oxford: Oxford University Press, 2009.

Bell, Avril. "Bifurcation or Entanglement? Settler Identity and Biculturalism in Aotearoa New Zealand.” Continuum 20, no. 2 (2006): 253-68.

. "Dilemmas of Settler Belonging: Roots, Routes and Redemption in New Zealand National Identity Claims." The Sociological Review 57, no. 1 (2009): 14562.

“We're Just New Zealanders': Pakeha Identity Politics." In Nga Patai: Racism and Ethnic Relations in Aotearoa/New Zealand, edited by Paul Spoonley, Cluny Macpherson and David Pearson, 144-58. Palmerston North: Dunmore Press, 1996. 
Bell, Claudia. Inventing New Zealand: Everyday Myths of Pakeha Identity. Auckland: Penguin, 1996.

. "The 'Real' New Zealand: Rural Mythologies Perpetuated and Commodified." The Social Science Journal 34, no. 2 (1997): 145-58.

Bennett, Andrew, and Nicholas Royle. An Introduction to Literature, Criticism and Theory.

New York: Pearson Longman, 2004.

Berger, Peter. "The Desecularization of the World: A Global Overview.” In The Desecularization of the World: Resurgent Religion and World, edited by Berger, 1-18. Michigan: Wm. B. Eerdmans, 1999.

Bernstein, Richard. "The Uneasy Tensions of Immanence and Transcendence." International Journal of Politics, Culture, and Society 21, no. 1-4 (December 2008): 1116.

Bluck, John. Long, White and Cloudy: In Search of a Kiwi Spirituality. Christchurch: Hazard Press, 1998.

Booksellers New Zealand. "About the NZ Post Book Awards." http://www.booksellers.co.nz/awards/new-zealand-post-book-awards/aboutnz-post-book-awards.

Bornholdt, Jenny. "Big Minty Nose." In Bornholdt, The Rocky Shore, 61-79. Wellington: Victoria University Press, 2008.

- "The Rocky Shore.” In Bornholdt, The Rocky Shore, 17-32. Wellington: Victoria University Press, 2008.

Bouma, Gary D. Australian Soul: Religion and Spirituality in the Twenty-First Century. Cambridge: Cambridge University Press, 2006.

Brasch, Charles. "The Silent Land." In The Penguin Book of New Zealand Verse, edited by Allen Curnow, 183-84 (Harmondsworth: Penguin, 1960).

Brooking, Tim. "But Where Are the People?” New Zealand Books 7, no. 4 (1997): 14-15.

Brown, Colin. "Christianity: Mainline Denominations to the 1960s." In Religions of New Zealanders, edited by Peter Donovan, 58-74. Palmerston North: Dunmore Press, 1996.

Brown, James. Introduction to The Nature of Things: Poems from the New Zealand Landscape, edited by Brown. Nelson: Craig Potton Publishing, 2005.

Bruce, Steve. God Is Dead: Secularization in the West, Religion and Modern World. Oxford: Blackwell Publishers, 2002.

Byrnes, Giselle. "Rethinking National Identity in New Zealand's History.” Paper presented at the Dominion Status Symposium, Legislative Council Chamber, 
Parliament Buildings, Wellington, 2007.

www.mch.govt.nz/dominion/byrnes.html

Caffin, Elizabeth. "Poetry, Part Two: 1945-1990s." In The Oxford History of New Zealand Literature in English, edited by Terry Sturm, 489-99. 1991. Reprint, Auckland: Oxford University Press, 1998.

Calder, Alex. "Blending and Belonging: Blanche Baughan and Scenic New Zealand." Journal of New Zealand Literature 23 (2005): 174-85.

"Unsettling Settlement: Poetry and Nationalism in Aotearoa / New Zealand." In Real: Yearbook of Research in English and American Literature 14, Literature and the Nation, edited by Thomas Brook, 165-81. Tubingen: Gunter Narr Verlag, 1998.

Campbell, Alistair. Response to "A Survey." Landfall 122 (June 1970). Quoted in Jackson, MacD P. "Poetry, Part One: Beginnings to 1945," in The Oxford History of New Zealand Literature in English, edited by Terry Sturm, 394-446. 1991. Reprint, Auckland: Oxford University Press, 1998, 402.

Casanova, José. Public Religions in the Modern World. Chicago: University of Chicago Press, 1994.

. "Rethinking Secularization: A Global Comparative Perspective." The Hedgehog Review 8, no. 1-2 (Spring \& Summer 2006): 7-22.

"The Secular and Secularisms." Social Research 76, no. 4 (Winter 2009): 1049-66.

Chakrabarty, Dipesh. "The Modern and the Secular in the West: An Outsider's View." Journal of the American Academy of Religion 77, no. 2 (June 2009): 393-403.

Charman, Janet. "lessons from the Waitakeres." In Charman, Cold Snack, 15. Auckland: Auckland University Press, 2007.

. "test test one two." In Charman, Cold Snack, 4. Auckland: Auckland University Press, 2007.

Chidgey, Catherine. In a Fishbone Church. Wellington: Victoria University Press, 1998.

Clifton, Jane. "Choice, Bro.” New Zealand Listener, July 3-9, 2010, 14-18.

Colquhoun, Glenn. “On the Death of My Grandmother." In Colquhoun, Playing God, 24-25. Wellington: Steele Roberts, 2002.

Courtney, Caroline. "Religion: Who Needs It?” North \& South, April 1, 2007, 66-77. http://web.ebscohost.com/

Cranna, John. “Archaeology.” In Cranna, Visitors, Pacific Writers Series. 50-65. Auckland: Heinemann Reed, 1989. 
"Visitors." In Cranna, Visitors, Pacific Writers Series. 1-15. Auckland:

Heinemann Reed, 1989.

Crittenden, Paul James. "A Secular Age: Reflections on Charles Taylor's Recent Book." Sopbia 48, no. 4 (November 2009): 469-78.

Crosby, Alfred. Ecological Imperialism: The Biological Expansion of Europe, 900-1900. Cambridge; New York: Cambridge University Press, 2004.

Culler, Jonathan. Literary Theory: A Very Short Introduction, Very Short Introductions. Oxford: Oxford University Press, 1997.

Curnow, Allen. "A Dialogue by Way of Introduction, with Ngaio Marsh," Yearbook of the Arts, 1. Wellington: Harry H Tombs, 1945. Quoted in "Unsettling Settlement: Poetry and Nationalism in Aotearoa / New Zealand.” In Real: Yearbook of Research in English and American Literature 14, Literature and the Nation, edited by Thomas Brook, 165-81. Tubingen: Gunter Narr Verlag, 1998, 165.

. "Dialogue with Four Rocks." In Curnow, You Will Know When You Get There: Poems 1979-81, 43-46. Auckland: Auckland University Press / Oxford University Press, 1982.

. "A Raised Voice." In Curnow, The Loop in Lone Kauri Road: Poems, 1983-1985, 9-10. Auckland: Auckland University Press; Oxford University Press, 1986.

. "The Weather in Tohunga Crescent." In Curnow, You Will Know When You Get There: Poems 1979-81, 13-15. Auckland: Auckland University Press / Oxford University Press, 1982.

. ed. A Book of New Zealand Verse, 1923-45. Christchurch: The Caxton Press, 1945.

— ed. The Penguin Book of New Zealand Verse, Harmondsworth: Penguin, 1960.

Dallas, Ruth. "Encounter." In Dallas, Walking on the Snow, 25. Christchurch: Caxton Press, 1976.

. "In Central Otago." In Dallas, Walking on the Snow, 9. Christchurch: Caxton Press, 1976.

. "Kyeburn Diggings." In Dallas, Walking on the Snow, 11. Christchurch: Caxton Press, 1976.

. "Living with a Cabbage Tree." In Dallas, Walking on the Snow, 22. Christchurch: Caxton Press, 1976.

. "A Warm Evening." In Dallas, Walking on the Snow, 15. Christchurch: Caxton Press, 1976.

Donovan, Peter. "Zeal and Apathy: The Future.” In Religions of New Zealanders, edited by Donovan, 258-69. Palmerston North: Dunmore Press, 1996. 
Dunlap, Thomas R. Nature and the English Diaspora: Environment and History in the United States, Canada, Australia, and New Zealand, Studies in Environment and History. Cambridge: Cambridge University Press, 1999.

During, Simon. "Postcolonialism and Globalisation: A Dialectical Relation after All?" Postcolonial Studies 1, no. 1 (1998): 31-47.

Dürr, Eveline. “Arcadia in the Antipodes: Tourists' Reflections on New Zealand as Nature Experience." Sites: A Journal for Radical Perspectives on Culture 4, no. 2 (2007): 57-82.

- "Reinforcing Cultural Hegemony: Pakeha Perceptions of Brand New Zealand." Journal of New Zealand Studies Oct 2007/2008, no. 6/7 (2007/2008): $59-76$.

. "Representing Purity: National Branding, Nature, and Identity in New Zealand.” Paper presented at the Transformations '07: Composing the Nation: Ideas, Peoples, Histories, Languages, Cultures, Economies. The Congress of Te Whāinga Aronui, The Council for the Humanities, Victoria University of Wellington, August 27-28, 2007. http://www.humanitiesresearch.net/news/ representing_purity_national_branding_nature_and_identity_in_new_zealand_1

Dyson, Lynda. "The Construction and Reconstruction of 'Whiteness' in New Zealand." British Review of New Zealand Studies 9 (December 1996): 55-69.

Edmond, Lauris. “The Beech Tree.” In Edmond, Selected Poems, 67-68. Auckland: Oxford University Press, 1984.

—_. "Jardin des Colombières." In Edmond, Selected Poems, 85. Auckland: Oxford University Press, 1984.

. "Moonshine Valley." In Edmond, Selected Poems, 11. Auckland: Oxford University Press, 1984.

. "Moreporks in Menton.” In Edmond, Selected Poems, 80. Auckland: Oxford University Press, 1984.

. "Pancakes for Breakfast." In Edmond, Selected Poems, 127. Auckland: Oxford University Press, 1984.

" "The Pear Tree." In Edmond, Selected Poems, 26. Auckland: Oxford University Press, 1984.

-. “September." In Edmond, Selected Poems, 122-23. Auckland: Oxford University Press, 1984.

. “Turning the Pear Tree to Paper.” In Edmond, Selected Poems, 30-31. Auckland: Oxford University Press, 1984.

"Wellington Letter (III)." In Edmond, Selected Poems, 45. Auckland: Oxford University Press, 1984. 
."Wellington Letter (XVI)." In Edmond, Selected Poems, 53-4. Auckland: Oxford University Press, 1984.

Eldred-Grigg, Stevan. Oracles \& Miracles. Auckland: Penguin, 1987.

Evans, Patrick. "On Originality: No Earth Tones." In Writing at the Edge of the Universe: Essays from the 'Creative Writing in New Zealand' Conference, University of Canterbury, August 2003, edited by Mark Williams, 68-84. Christchurch: Canterbury University Press, 2004.

_. "Spectacular Babies: The Globalisation of New Zealand Fiction." Journal of Postcolonial Writing 38, no. 2 (2000): 94-109.

Fairburn, Miles. The Ideal Society and Its Enemies: The Foundations of Modern New Zealand Society, 1850-1900. Auckland: Auckland University Press, 1989.

_ . "Is There a Good Case for New Zealand Exceptionalism?," Thesis Eleven 92 (2008): 29-49.

Falcous, Mark. "The Decolonizing National Imaginary: Promotional Media Constructions During the 2005 Lions Tour of Aotearoa New Zealand." Journal of Sport and Social Issues 31, no. 4 (2007): 374-93.

Farrell, Fiona. The Skinny Louie Book. Auckland: Penguin, 1992.

Flannery, Tim. The Future Eaters: An Ecological History of the Australasian Lands and People. Chatswood, N.S.W.: Reed Books, 1995.

Fleras, Augie, and Paul Spoonley. Recalling Aotearoa: Indigenous Politics and Ethnic Relations in New Zealand. Auckland: Oxford University Press, 1999.

Fletcher, Beryl. The Word Burners. Wellington: Daphne Brasell Associates, 1991.

Frame, Janet. The Carpathians. 1998. Reprint, Auckland: Vintage, 2005.

—. Living in the Maniototo. 1981. Reprint, London: Women's Press, 1991.

Gee, Maurice. "Eleventh Holiday.” In Gee, A Glorious Morning, Comrade, 192-99. Auckland: Auckland University Press, 1975.

—. Going West. Auckland: Viking, 1992.

-. Meg. London: Faber, 1981.

—_. "Right-Hand Man." In Gee, A Glorious Morning, Comrade, 173-91. Auckland: Auckland University Press, 1975.

_. "The Widow." In Gee, A Glorious Morning, Comrade, 9-27. Auckland: Auckland University Press, 1975. 
Geering, Lloyd. 2100, A Faith Odyssey: The Changing Face of New Zealand Religion. Wellington: St Andrews Trust for the Study of Religion \& Society, 1995.

. "New Zealand Enters the Secular Age." In Religion in New Zealand, edited by Christopher Nichol and James Veitch, 161-186. 2nd ed. Wellington: Christopher Nichol / Victoria University of Wellington, 1983.

Gibbons, Peter. "The Far Side of the Search for Identity: Reconsidering New Zealand History." New Zealand Journal of History 37, no. 1 (2003): 1-10.

Goldie, Terry. Fear and Temptation: The Image of the Indigene in Canadian, Australian and New Zealand Literatures. Kingston, Ontario: McGill-Queen's University Press, 1989.

Gordon, Peter E. "The Place of the Sacred in the Absence of God: Charles Taylor's a Secular Age." Journal of the History of Ideas 69, no. 4 (2008): 647-73.

Grimshaw, Mike. "I to the Hills Will Lift Mine Eyes, from Whence Will Come My Aid!' or, Pakeha and the Condition of Modernity." Paper presented at the Transformations '07: Composing the Nation: Ideas, Peoples, Histories, Languages, Cultures, Economies. The Congress of Te Whāinga Aronui, The Council for the Humanities, Victoria University of Wellington, August 27-28, 2007. http://www.humanitiesresearch.net/news/ i_to_the_hills_will_lift_mine_eyes_from_whence_will_come_my_aid_or_pakeh a_and_the_condition_of_modernity

Grossmann, Edith Searle. "The Growth of a Colonial Settlement." Cited in Keith Sinclair, A Destiny Apart: New Zealand's Search for National Identity. (Auckland, Allen \& Unwin, 1986), 6.

Guthrie-Smith, Herbert. Bird Life on Island and Shore. Edinburgh: William Blackwood and Sons, 1925.

- Sorrows and Joys of New Zealand Naturalist. Dunedin: AH and AW Reed, 1936.

- Tutira: The Story of a New Zealand Sheep Station. 4th ed. Auckland: Random House, 1999.

Hall, Stuart. "Cultural Identity and Diaspora." In Theorizing Diaspora: A Reader, edited by Jana Evans Braziel and Anita Mannur, 233-46. Malden, MA: Blackwell, 2003.

. "Introduction: Who Needs 'Identity'?” In Questions of Cultural Identity, edited by Stuart Hall and Paul du Gay, 1-17. London: Sage, 1996.

Hawken, Dinah. "Winter. New York." In Hawken, It Has No Sound and Is Blue, 43.

Wellington: Victoria University Press, 1987.

"Writing Home, (5)." In Hawken, It Has No Sound and Is Blue, 27. Wellington: Victoria University Press, 1987.

" Writing Home, (7)." In Hawken, It Has No Sound and Is Blue, 29. Wellington: Victoria University Press, 1987. 
Heelas, Paul. "Challenging Secularization Theory: The Growth Of 'New Age' Spiritualities of Life." The Hedgehog Review 8, no. 1-2 (Spring \& Summer 2006): 46-58.

—. The New Age Movement. Oxford: Blackwell, 1996.

Hervieu-Léger, Danièle. "In Search of Certainties: The Paradoxes of Religiosity in Societies of High Modernity." The Hedgehog Review 8, no. 1-2 (Spring \& Summer 2006): 59-68.

Holcroft, M.H. Discovered Isles: A Trilogy. Christchurch: The Caxton Press, 1950.

Hooper, Peter. People of the Long Water. Dunedin: McIndoe, 1985.

Hoverd, William James. "No Longer a Christian Country? - Religious Demographic Change in New Zealand 1966 - 2006." New Zealand Sociology 23, no. 1 (2008): 41 65.

Hoverd, William James, and Chris G. Sibley. "Religious and Denominational Diversity in New Zealand 2009." New Zealand Sociology 25, no. 2 (2010): 59-87.

Ireland, Kevin. "The Literary Exile." In Ireland, Literary Cartoons, 18. Auckland: Islands/Hurricane, 1977.

Jackson, MacD P. "Poetry, Part One: Beginnings to 1945." In The Oxford History of New Zealand Literature in English, edited by Terry Sturm, 394-446. 1991. Reprint, Auckland: Oxford University Press, 1998.

Jackson, Michael. “Bird on the Wire.” In Jackson, Pieces of Music, 150-167. Auckland: Vintage New Zealand, 1994.

—. "Just Like This Train.” In Jackson, Pieces of Music, 88-100. Auckland: Vintage New Zealand, 1994.

—. "Pioneers." In Jackson, Wall, 10. Dunedin: McIndoe, 1980.

Jagose, Annamarie. Slow Water. Wellington: Victoria University Press, 2003.

Johnson, Andrew. "Revisionism (I. The Present Tense)." In Johnson, How to Talk, 9. Wellington: Victoria University Press, 1993.

Johnson, Stephanie. The Shag Incident. Auckland: Vintage, 2002.

Jones, Lawrence. “The Novel." In The Oxford History of New Zealand Literature in English, edited by Terry Sturm. 1991. Reprint, Auckland: Oxford University Press, 1998.

- Picking up the Traces: The Making of a New Zealand Literary Culture, 1932-1945. Wellington: Victoria University Press, 2004. 
"Versions of the Dream: Literature and the Search for Identity." In Culture and Identity in New Zealand, edited by David Novitz and Bill Willmott, 187-211. Wellington: GP Books, 1989.

Jones, Lloyd. The Book of Fame. Auckland: Penguin, 2000.

Keith, Sheridan. Zoology. Auckland: Penguin, 1995.

Kennedy, Anne. “Whenua (1).” In Kennedy, Sing Song, 25-27. Auckland: Auckland University Press, 2003.

—. "Whenua (2)." In Kennedy, Sing Song, 123. Auckland: Auckland University Press, 2003.

Kidman, Fiona. The Book of Secrets. Auckland: Picador, 1988.

—. The Captive Wife. Auckland: Vintage, 2005.

King, Michael. Being Pakeha Now: Reflections and Recollections of a White Native. Auckland: Penguin, 1999.

_. Pakeha: The Quest for Identity in New Zealand. Auckland: Penguin, 1991.

—. The Penguin History of New Zealand. Auckland: Penguin, 2003.

Lawson, Alan. "Postcolonial Theory and the 'Settler' Subject." Essays on Canadian Writing 56 (1995): 20-36.

Lineham, Peter. "Government Support of Churches in the Modern Era." In God and Government: The New Zealand Experience, edited by Rex Ahdar and John Stenhouse, 41-58. Dunedin: University of Otago Press, 2000.

Liu, James H. "History and Identity: A System of Checks and Balances for Aotearoa/New Zealand." In New Zealand Identities: Departures and Destinations, edited by James Liu, Tim McCreanor, Tracey McIntosh, and Teresia Teaiwa, 6987. Wellington: Victoria University Press, 2005.

Luckmann, Thomas. "Shrinking Transcendence, Expanding Religion?” Sociological Analysis 51, no. 2 (Summer 1990): 127-38.

Manhire, Bill. "Milky Way Bar.” In Manhire, Milky Way Bar, 19. Wellington: Victoria University Press, 1991.

"Poem for Vanessa." In Manhire, Zoetropes: Poems, 1972-82, 66-67. Wellington: Port Nicholson Press, 1984.

Marshall, Owen. Harlequin Rex. Auckland: Vintage, 1999.

Matheson, Peter. "The Myth of a Secular New Zealand." Pacifica: Journal of the Melbourne College of Divinity 19, no. 2 (June 2006): 177-92. 
Mathewes, Charles T. “An Interview with Peter Berger.” The Hedgehog Review 8, no. 1-2 (Spring \& Summer 2006): 152-61.

McCallum, Mary. The Blue. Rosedale, N.Z.: Penguin, 2007.

McNaughton, Trudie, ed. Countless Signs: The New Zealand Landscape in Literature. Auckland: Reed Methuen Publishers Ltd, 1986.

McQueen, Cilla. Berlin Diary. Dunedin: John McIndoe, 1990.

"Hoopers Inlet.” In McQueen, Benæina, edited by Iain M. Lonie, 15. Dunedin: John McIndoe, 1988.

. "Low Tide, Aramoana." In McQueen, Homing In, 24-25. Dunedin: John McIndoe, 1982.

“'Rock Poem, Carey's Bay.” In McQueen, Homing In, 52-53. Dunedin: John McIndoe, 1982.

"Songs for a Far Island.” In McQueen, Homing In, 30-34. Dunedin: John McIndoe, 1982.

“A Walk on the Hill.” In McQueen, Homing In, 27. Dunedin: John McIndoe, 1982.

. "Weather Poem, Sydney." In McQueen, Homing In, 18-19. Dunedin: John McIndoe, 1982.

—_. "Words Fail Me.” In McQueen, Homing In, 42-43. Dunedin: John McIndoe, 1982.

"Yes Evening Is a Nice Time Full of Promises." In McQueen, Homing In, 2021. Dunedin: John McIndoe, 1982.

Middleton, O.E. “A Married Man.” In Middleton, Selected Stories, 129-50. Dunedin: John McIndoe, 1975.

Miller, James. "What Secular Age?" International Journal of Politics, Culture, and Society 21, no. 1-4 (December 2008): 5-10.

Morris, Meaghan. “Afterthoughts on 'Australianism'.” Cultural Studies 6, no. 3 (October 1992): 468-75.

Morris, Paul. "Celts, Oracles and Crystals.” New Zealand Books 7, no. 3 (1997): 12-13.

- "Fragments of Faith: Religion in Contemporary New Zealand." New Zealand Studies 9, no. 1 (March 1999): 15-21.

- "New Zealand Spirituality: A Time for Re-Enchantment." In Spirit in a Strange Land: A Selection of New Zealand Spiritual Verse, edited by Paul Morris, Harry Ricketts, and Mike Grimshaw, 182-89. Auckland: Godwit, 2001. 
"Spirituality Abroad: Reflections on New Zealand Spirituality and Identity." In Spirit Abroad: A Second Selection of New Zealand Spiritual Verse, edited by Paul Morris, Harry Ricketts, and Mike Grimshaw, 217-29. Auckland: Godwit, 2004.

"Who Are We? New Zealand Identity and Spirituality." In New Zealand Identities: Departures and Destinations, edited by James Liu, Tim McCreanor, Tracey McIntosh, and Teresia Teaiwa, 242-54. Wellington: Victoria University Press, 2005.

Morris, Paul, and Harry Ricketts. "Irreverent but Not Irreligious--Good Kiwi Joker Spirituality from Allen Curnow to Flight of the Conchords." Landfall 215 (2009): 95-104.

Morris, Paul, Harry Ricketts, and Mike Grimshaw. Introduction to Spirit in a Strange Land: A Selection of New Zealand Spiritual Verse, edited by Morris, Ricketts, and Grimshaw, 9-14. Auckland: Godwit, 2001.

New Zealand Book Council. "Hulme, Keri." http://www.bookcouncil.org.nz/Writers/ Profiles/Hulme, Keri.

— . "The Writers Files." http://www.bookcouncil.org.nz/Writers/ Information/ Introduction.htm.

New Zealand Listener. “The Good Books.” June 13-19, 2009. http://www.listener.co.nz/ issue/3605/columnists/13441/ the_good_books.html.

O'Sullivan, Vincent. “The Boy, the Bridge, the River." In O'Sullivan, The Boy, the Bridge, the River, 89-142. Dunedin: J. McIndoe, 1978.

. "End." In O'Sullivan, The Boy, the Bridge, the River, 62-88. Dunedin: J. McIndoe, 1978.

—. Let the River Stand. Auckland: Penguin, 1993.

"Visitors." In O'Sullivan, The Boy, the Bridge, the River, 45-61. Dunedin: J. McIndoe, 1978.

Opie, Stephen. "Bible Engagement in New Zealand: Survey of Attitudes and Behaviour, March - June 2008.” The Bible Society. http://biblesociety.org.nz/mediafiles/ bible-society-research-2008.pdf.

Park, Geoff. “A Moment for Landscape.” In Park, Theatre Country: Essays on Landscape and Whenua 196-204. Wellington: Victoria University Press, 2006.

- Ngā Uruora: The Groves of Life, Ecology and History in a New Zealand Landscape. Wellington: Victoria University Press, 1995.

Pawson, Eric. "Postcolonial New Zealand?” In Cultural Geographies, edited by Kay Anderson and Fay Gale, 25-50. Melbourne: Longman, 1999. 
Pearson, David. "Pakeha Ethnicity: Concept or Conundrum." Sites: A Journal for Radical Perspectives on Culture 18 (Winter 1989): 61-72.

Pickles, Katie. "Kiwi Icons and the Re-Settlement of New Zealand as Colonial Space." New Zealand Geographer 58, no. 2 (2002): 5-16.

Poata-Smith, Evan Te Ahu. "He Pokeke Uenuku I Tu Ai: The Evolution of Contemporary Maori Protest." In Ngà Patai: Racism and Ethnic Relations in Aotearoa/New Zealand, edited by Paul Spoonley, David Pearson and Cluny Macpherson, 97-116. Palmerston North: Dunmore Press, 1996.

Randall, Charlotte. Dead Sea Fruit. Auckland: Secker \& Warburg / Reed Books, 1995.

Roberts, Hugh. 'Can Identity Be Helped? 'Landfall', Chaos, and the Creation of a New Zealand National Literature.” Journal of New Zealand Literature 14 (1996): 24-60.

. "The Same People Living in Different Places: Allen Curnow's Anthology and New Zealand Literary History.” Modern Language Quarterly 64, no. 2 (June 2003): 219-37.

Robinson, Roger, and Nelson Wattie, eds. The Oxford Companion to New Zealand Literature. Melbourne: Oxford University Press, 1998.

Ross, Kirstie. Going Bush: New Zealanders and Nature in the 20th Century. Auckland: Auckland University Press, 2008.

Schama, Simon. Landscape and Memory. London: Fontana Press, 1996.

Schultz, Kevin M. "Secularization: A Bibliographic Essay." The Hedgehog Review 8, no. 1 2 (Spring \& Summer 2006): 170-77.

Shadbolt, Maurice. The Lovelock Version. London: Hodder and Stoughton, 1980.

- Season of the Jew. London: Hodder and Stoughton, 1986.

Simpson, Peter. "A Country in Search of Itself." In Writing at the Edge of the Universe: Essays from the 'Creative Writing in New Zealand' Conference, University of Canterbury, August 2003, edited by Mark Williams, 123-140. Christchurch: Canterbury University Press, 2004.

Sinclair, Keith. A Destiny Apart: New Zealand's Search for National Identity. Wellington: Allen \& Unwin, 1986.

-. Towards 1990: Nation and Identity, Hocken Lecture 1988. Dunedin: The Hocken Library, University of Otago, 1990.

Smithyman, Kendrick. "Legend of Sara's Gully." In Smithyman, Stories About Wooden Keyboards, 33. Auckland: Auckland University Press, 1985.

"Movements for Coastal Voices, (3)." In Smithyman, Stories About Wooden Keyboards, 35. Auckland: Auckland University Press, 1985. 
—. "Reading the Maps, An Academic Exercise." In Smithyman, Stories About Wooden Keyboards, 39-50. Auckland: Auckland University Press, 1985.

Spoonley, Paul. Racism and Ethnicity, Critical Issues in New Zealand Society. Auckland: Oxford University Press, 1988.

Spoonley, Paul, Cluny Macpherson, David Pearson, and Charles Segdwick. Introduction to Nga Tauiwi: Racism and Ethnicity in New Zealand, edited by Spoonley, Macpherson, Pearson, and Segdwick, 9-14. Palmerston North: Dunmore Press, 1984.

Stachurski, Christina. Reading Pakeha?: Fiction and Identity in Aotearoa New Zealand, Cross/Cultures 109. Amsterdam: Rodopi, 2009.

Stafford, Jane. "Going Native: How the New Zealand Settler Became Indigenous." Journal of New Zealand Literature 23 (2005): 162-73.

Statistics New Zealand. “Are New Zealanders Living Closer to the Coast?” Internal Migration, Analytical Report. http://www.stats.govt.nz/browse_for_stats/ population/ migration/internal-migration/are-nzs-living-closer-to-coast.aspx.

"New Zealand Religious Affiliation 2006." http://www.stats.govt.nz/Census/ 2006CensusHomePage/QuickStats/quickstats-about-a-subject/culture-andidentity/religious-affiliation.aspx

Stead, C.K. "9 X 14 - the Yellow Sonnets (1).” In Stead, Quesada: Poems, 1972-74, 35. Auckland: The Shed, 1975.

"9 X 14 - the Yellow Sonnets (4)." In Stead, Quesada: Poems, 1972-74, 36-37. Auckland: The Shed, 1975.

"9 X 14 - the Yellow Sonnets (6)." In Stead, Quesada: Poems, 1972-74, 38. Auckland: The Shed, 1975.

“For a Children's L.P (Ecology)." In Stead, Quesada: Poems, 1972-74, 34. Auckland: The Shed, 1975.

"Keri Hulme's 'The Bone People' and the Pegasus Award for Maori Literature." Ariel: A Review of International English Literature 16, no. 4 (1985): 101 08. . The Singing Whakapapa. Auckland: Penguin, 1994.

Steer, Philip. "History (Never) Repeats: Pakeha Identity, Novels and the New Zealand Wars." Journal of New Zealand Literature 25 (2007): 114-37.

Sturm, Terry. "Popular Fiction." In The Oxford History of New Zealand Literature in English, edited by Terry Sturm, 575-630. 1991. Reprint, Auckland: Oxford University Press, 1998. 
Tacey, David. Edge of the Sacred: Jung, Psyche, Earth. Einsiedeln, Switzerland Daimon Verlag, 2009.

- The Spirituality Revolution: The Emergence of Contemporary Spirituality. East Sussex: Routledge, 2005.

Taylor, Charles. A Secular Age. Cambridge, Mass.: Belknap Press of Harvard University Press, 2007.

Thomson, Margie. "Judgment Day for the Montana Book Awards." New Zealand Herald, July 20, 2002. http://www.nzherald.co.nz/margie-thomson/news/ article.cfm?a_id $=108 \&$ objectid $=2098172$

THR. “After Secularization.” The Hedgehog Review 8, no. 1-2 (Spring-Summer 2006): 5-6.

Tourism New Zealand. Pure As: Celebrating 10 Years of 100\% Pure New Zealand. 2009. http://www.tourismnewzealand.com/media/106877/10 year anniversary of 100 pure new zealand campaign - pure as magazine.pdf.

Trussell, Denys. "Nature and the Pakeha." In Trussell, The Expressive Forest: Essays on the Arts and Ecology in Oceania, 15-31. Auckland: Brick Row Publishing, 2008.

Turei, Metiria. The Green Party of Aotearoa New Zealand. "The Ultimate Earth Day Present." Apr 22, 2010. http://www.greens.org.nz/press-releases/ultimateearth-day-present.

Turner, Brian. “Always the Hills.” In Turner, Ladders of Rain, 37. Dunedin: John McIndoe, 1978.

—. "Brothers." In Turner, Beyond, 35. Dunedin: McIndoe, 1992.

—. “The Fat Boy.” In Turner, Beyond, 44. Dunedin: McIndoe, 1992.

_. "Graduation." In Turner, Ladders of Rain, 26. Dunedin: John McIndoe, 1978.

—. "In the Nineties." In Turner, Beyond, 7-8. Dunedin: McIndoe, 1992.

. "Madness and the Mountain." In Turner, Ladders of Rain, 34-37. Dunedin: John McIndoe, 1978.

—_. "Pastoral." In Turner, Ladders of Rain, 41. Dunedin: John McIndoe, 1978.

—. "Van Morrison in Central Otago." In Turner, Beyond, 10-11. Dunedin: McIndoe, 1992.

. "Watch for the Ice." In Turner, Ladders of Rain, 26. Dunedin: John McIndoe, 1978.

"Yokels.” In Turner, Beyond, 56-57. Dunedin: McIndoe, 1992. 
Turner, Stephen. "Being Colonial/Colonial Being." Journal of New Zealand Literature 20 (2002): 39-66.

Upton, Simon. "Making It All Irreversibly Ours." New Zealand Books 6, no. 5 (1996): 1517.

Veitch, James. "Christianity: Protestants since the 1960s.” In Religions of New Zealanders, edited by Peter Donovan, 90-103. Palmerston North: Dunmore Press, 1996.

Wevers, Lydia. "Being Pakeha: The Politics of Location." Journal of New Zealand Studies, no. 4-5 (2005-2006): 1-10.

—. "The Short Story." In The Oxford History of New Zealand Literature in English, edited by Terry Sturm, 245-320. 1991. Reprint, Auckland: Oxford University Press, 1998.

Whyte, Lis, ed. New Zealand Books in Print. Wellington: DW Thorpe, 1995.

Wilkins, Damien. The Miserables. Wellington: Victoria University Press, 1993.

Williams, Mark. Introduction to Writing at the Edge of the Universe: Essays from the 'Creative Writing in New Zealand' Conference, University of Canterbury, August 2003, edited by Mark Williams, 7-19. Christchurch: Canterbury University Press, 2004.

_. "Travels in Maoriland, 1907-1999." New Zealand Books 9, no. 5 (1999): 2-3. 